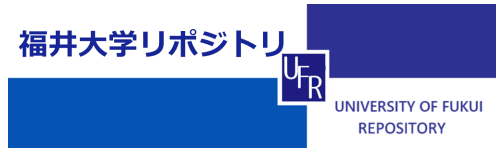

React i on bet ween Carbon Di oxi de and El ement ary Fl uor i ne

\begin{tabular}{|l|l|}
\hline 著者 (英) & 安男 長谷川 \\
\hline 学位名 & 博士(工学) \\
\hline 学位授与機関 & 福开大学 \\
\hline 学位授与番号 & 工博甲第264号 \\
\hline URL & ht t p: //hdl . handl e. net /10098/1665 \\
\hline
\end{tabular}


A Dissertation Submitted to the

University of Fukui for the Degree of

Doctor of Engineering

\section{Reaction between Carbon Dioxide and Elementary Fluorine}

March 2008

Yasuo Hasegawa 


$$
\begin{gathered}
\text { To } \\
\text { my family }
\end{gathered}
$$




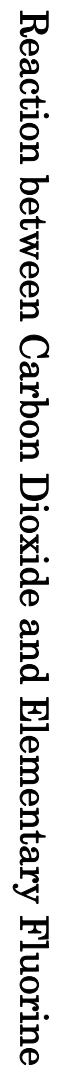

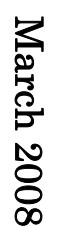

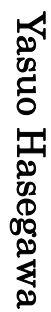




\section{Preface}

The study presented here has been carried out as the Doctor dissertation under the direction of Professor Dr. Masayuki Takashima, Center for Cooperative Research, University of Fukui, and Associate Professor Dr. Susumu Yonezawa, Department of Materials Science and Engineering, University of Fukui. The purpose of this work is to investigate the reaction between carbon dioxide and elementary fluorine. The author wishes that this study would lead to further development of technology for human life.

First, I would like to express my appreciation to Professor Dr. Masayuki Takashima for giving me the opportunity to take part in this exciting research project and offering me his suggestions, support, and patience throughout the process. Also, I would like to thank Associate Professor Dr. Susumu Yonezawa for his direction, advice, comments and helpful support throughout this work. This successful completion owes much to the support of them.

I could meet Professor Dr. Yoshio Yamada during my study. I also thank you for your friendship and guidance.

I am greatly indebted to the entire crew at the Inorganic Material Chemistry Laboratory of University of Fukui and the Forensic Science Laboratory of Fukui Prefectural Police Headquarters who helped and encouraged this work in various ways. My sincere gratitude is given to many peoples and I am thankful to my young colleagues and past members at Takashima Lab, Mr. Hiroyasu Otsuka, Mr. Satoshi Ueda, Mr. Takashi Yagi, Miss Reiko Otani, Mr. Akitomo Nagasaka, Mr. Hidezi Fukaya, Mr. 
Shigeyuki Kimura, Dr. Shiori Nishibu and Dr. Jae-Ho Kim for their cooperation and support. Also, I wish to show my gratitude for the warm encouragement and support of my office members, Mr. Shigeki Matsumura, Mr. Tetsuya Tsukahara and Mr. Fukuzo Masuyama.

We gratefully acknowledge that the GC / FT-IR spectra were acquired for us by Mr. Mamoru Komatsu of Thermo Nicolet Japan Inc.

Once again, the success of this dissertation will owe a great deal to the peoples and groups mentioned above and I am very grateful to them for their contributions. 


\section{Table of contents}

\section{Preface}

List of Figures

General Introduction 1

1 Global warming 1

2 Reaction between $\mathrm{CO}_{2}$ and $\mathrm{F}_{2} \quad 2$

3 Objective of this study

$\begin{array}{lr}\text { References and notes } & 6\end{array}$

Chapter 1. Reaction between carbon dioxide and elementary fluorine $\quad 9$

$\begin{array}{lr}1.1 \text { Introduction } & 9\end{array}$

$\begin{array}{ll}\text { 1.1.1 Properties of fluorine } & 10\end{array}$

$\begin{array}{ll}\text { 1.1.2 New energy cycle with } \mathrm{CO}_{2} \text { fixing process } & 13\end{array}$

$\begin{array}{ll}1.2 \text { Experimental } & 14\end{array}$

$\begin{array}{ll}1.3 \text { Results and Discussion } & 18\end{array}$

$\begin{array}{ll}1.3 .1 \text { Reaction product } & 18\end{array}$

1.3.2 In the presence of metal fluorides 24

$\begin{array}{ll}1.3 .3 \text { Yields } & 31\end{array}$

$\begin{array}{ll}\text { 1.3.4 Reaction rate } & 36\end{array}$

$\begin{array}{ll}\text { 1.3.5 Activation energy of } \mathrm{COF}_{2} \text { formation } & 37\end{array}$ 
Chapter 2. Preparation of $\mathrm{COF}_{2}$ using $\mathrm{CO}_{2}$ and $\mathrm{F}_{2}$ in the electrochemical cell with $\mathrm{PbSnF}_{4}$ as a solid electrolyte

2.1 Introduction

2.1.1 What is a $\mathrm{CO}_{2} / \mathrm{F}_{2}$ electrochemical cell?

2.1.2 Electrochemical impedance spectroscopy

2.2 Experimental

2.2.1 Preparation of $\mathrm{PbSnF}_{4}$

2.2.2 Characterization of $\mathrm{PbSnF}_{4}$

2.2.3 Preparation of $\mathrm{COF}_{2}$

$\begin{array}{ll}2.3 \text { Results and Discussion } & 58\end{array}$

$\begin{array}{ll}\text { 2.3.1 Preparation of } \mathrm{PbSnF}_{4} & 58\end{array}$

2.3.2 Electrochemical properties 63

2.3.3 Preparation of $\mathrm{COF}_{2}$ in an electrochemical cell 67

$\begin{array}{ll}\text { References and notes } & 70\end{array}$

Chapter 3. Conclusion and future work $\quad 73$

$\begin{array}{ll}3.1 \text { Conclusion } & 73\end{array}$

$\begin{array}{ll}\text { 3.1.1 Chapter } 1 & 73\end{array}$

$\begin{array}{ll}\text { 3.1.2 Chapter } 2 & 74\end{array}$

$\begin{array}{ll}3.2 \text { Future work } & 75\end{array}$ 
Articles of other works 


\section{List of Figures}

Fig. 1.1. Apparatus for the reaction between $\mathrm{CO}_{2}$ and $\mathrm{F}_{2}$. (a) Gas-gas

reaction line, (b) trap-to-trap separation line and (c) vacuum line. (1) $\mathrm{CO}_{2}$ gas storage, (2) $\mathrm{F}_{2}$ gas storage, (3) reactor (SUS316L), (4) constant volume container, (5) reactor pressure gauge, (6) $\mathrm{CO}_{2}$ gas pressure gauge, (7) $\mathrm{F}_{2}$ gas pressure gauge, (8) PIRANI gauge, (9) Ar or He gas cylinder, (10) gas sampler, (11) activated alumina, (12) trap (liq. $\mathrm{N}_{2}$ ), and (13) vacuum pump (oil rotary)

Fig. 1.2. Calibration lines of $\mathrm{CO}_{2}(\mathrm{a}), \mathrm{COF}_{2}(\mathrm{~b}), \mathrm{CF}_{3} \mathrm{OF}$ (c) and $\mathrm{CF}_{4}(\mathrm{~d})$. (b) -1 and (b) -2 correspond, respectively, to data at $1930 \mathrm{~cm}^{-1}$ in Ref. [17] and Ref. [18]. (c)-1, (c)-2 and (c)-3 correspond to data at $1282 \mathrm{~cm}$ ${ }^{-1}$ in Ref. [19], at 1282 and at $945 \mathrm{~cm}^{-1}$ measured in this study

Fig. 1.3. Transient of the pressure change in the direct reactions at (a) $373 \mathrm{~K}$, (b) $423 \mathrm{~K}$, (c) $473 \mathrm{~K}$, (d) $498 \mathrm{~K}$ and (e ) $523 \mathrm{~K} . \mathrm{CO}_{2}: \mathrm{F}_{2}=50.7$ $\mathrm{kPa}: 101.3 \mathrm{kPa}$ and reaction time $50 \mathrm{~h}$

Fig. 1.4. FT-IR spectrum of the product in the direct reaction. $\mathrm{CO}_{2}: \mathrm{F}_{2}$ $=76 \mathrm{kPa}: 76 \mathrm{kPa}$, reaction temp. $498 \mathrm{~K}$, and reaction time $24 \mathrm{~h}$

Fig. 1.5. Gram-Schmide spectra of the product measured using GC / FT-IR. $\mathrm{CO}_{2}: \mathrm{F}_{2}=50.7 \mathrm{kPa}: 101.3 \mathrm{kPa}$, reaction temp. $498 \mathrm{~K}$, and reaction time $50 \mathrm{~h}$

Fig. 1.6. GC / FT-IR spectra of the products at retention times of 18.95-18.96 $\min (\mathrm{a}), 19.04-19.06 \mathrm{~min}(\mathrm{~b})$ and $19.23-19.27 \mathrm{~min}$ (c). $\mathrm{CO}_{2}: \mathrm{F}_{2}=50.7 \mathrm{kPa}: 101.3 \mathrm{kPa}$, reaction temp. $498 \mathrm{~K}$, and reaction time $50 \mathrm{~h}$ 
Fig. 1.7. GC / EI-MS spectra of the products. (a) Total ion chromatogram, (b) mass chromatogram at $\mathrm{m} / \mathrm{z}=69,66,47$ and 44 , (c) mass spectra at the retention time of $9.02 \mathrm{~min},(\mathrm{~d})$ at the retention time of $9.15 \min . \mathrm{CO}_{2}: \mathrm{F}_{2}=50.7 \mathrm{kPa}: 101.3 \mathrm{kPa}$, reaction temp. $498 \mathrm{~K}$, reaction time $40 \mathrm{~h}$, and GC oven temperature $223 \mathrm{~K}$

Fig. 1.8. FT-IR spectra of products in the presence of $\mathrm{CsF}$ at various temperatures. $\mathrm{CO}_{2}: \mathrm{F}_{2}=76 \mathrm{kPa}: 76 \mathrm{kPa}$, reaction time $50 \mathrm{~h}$. Sampling amount $2 \mathrm{kPa}(\mathrm{a})$ and $0.4 \mathrm{kPa}(\mathrm{b})$

Fig. 1.9. Mass chromatogram and MS spectra of the products in the presence of CsF. (a) Mass chromatogram at $\mathrm{m} / z=69,66$ and 47, (b) mass spectra at the retention time of $9.04 \mathrm{~min}$, (c) at the retention time of $9.17 \mathrm{~min}$ and (d) at the retention time of $9.39 \mathrm{~min} . \mathrm{CO}_{2}: \mathrm{F}_{2}=76$ $\mathrm{kPa}: 76 \mathrm{kPa}$, reaction temp. $498 \mathrm{~K}$, reaction time $50 \mathrm{~h}$, and $\mathrm{GC}$ oven temperature $223 \mathrm{~K}$

Fig. 1.10. Mass chromatograms of the products obtained in the presence of CsF at (a) $303 \mathrm{~K}$, (b) $423 \mathrm{~K}$, (c) $473 \mathrm{~K}$ and (d) $498 \mathrm{~K} . \mathrm{CO}_{2}$ : $\mathrm{F}_{2}=76 \mathrm{kPa}: 76 \mathrm{kPa}$, reaction time $50 \mathrm{~h}$, and GC oven temperature 243 K

Fig. 1.11. Mass chromatogram of the products in the presence of CsF at the reaction temperature of $303 \mathrm{~K}$. (a) Mass chromatograms at $\mathrm{m} / \mathrm{z}$ $=69,66$ and 47 after (a)-1 0 and (a)-2 4 days. (b) Mass spectra of the sample in (a)-1 having the retention time of (b)-1 $9.01 \mathrm{~min},(\mathrm{~b})-29.16$ min, (b)-3 $9.23 \min$ and (b)-4 $9.37 \min . \mathrm{CO}_{2}: \mathrm{F}_{2}=76 \mathrm{kPa}: 76 \mathrm{kPa}$, reaction time $50 \mathrm{~h}$, and $\mathrm{GC}$ oven temperature $223 \mathrm{~K}$ 
Fig. 1.12. XPS F1s spectrum of $\mathrm{CsF}$ before and after the reaction. (a)

Before reaction: (a)-1 non-etching and (a)-2 after etching; (b) after reaction: (b) -1 non-etching and (b) -2 after etching

Fig. 1.13. Yields of products in the direct reactions at various temperatures. $\mathrm{CO}_{2}: \mathrm{F}_{2}=76 \mathrm{kPa}: 76 \mathrm{kPa}$ and reaction time $50 \mathrm{~h} .(\mathrm{O})$ $\mathrm{CF}_{2} \mathrm{O},(\triangle) \mathrm{CF}_{3} \mathrm{OF},(\square) \mathrm{CF}_{4},(\diamond) \mathrm{CF}_{3} \mathrm{OOCF}_{3}$ and $(\times) \mathrm{CF}_{2}(\mathrm{OF})_{2}$

Fig. 1.14. Yields of products in the presence of $\mathrm{CsF}$ at various temperatures. $\mathrm{CO}_{2}: \mathrm{F}_{2}=76 \mathrm{kPa}: 76 \mathrm{kPa}$ and reaction time $50 \mathrm{~h} .(\bigcirc)$ $\mathrm{CF}_{2} \mathrm{O},(\triangle) \mathrm{CF}_{3} \mathrm{OF},(\square) \mathrm{CF}_{4},(\diamond) \mathrm{CF}_{3} \mathrm{OOCF}_{3}$ and $(\times) \mathrm{CF}_{2}(\mathrm{OF})_{2}$

Fig. 1.15. Yields of products in the presence of $\mathrm{EuF}_{3}$ at various temperatures. $\mathrm{CO}_{2}: \mathrm{F}_{2}=76 \mathrm{kPa}: 76 \mathrm{kPa}$ and reaction time $50 \mathrm{~h} .(\bigcirc)$ $\mathrm{CF}_{2} \mathrm{O},(\triangle) \mathrm{CF}_{3} \mathrm{OF},(\square) \mathrm{CF}_{4},(\diamond) \mathrm{CF}_{3} \mathrm{OOCF}_{3}$ and $(\times) \mathrm{CF}_{2}(\mathrm{OF})_{2}$

Fig. 1.16. Yields of products in the direct reaction at $498 \mathrm{~K}$ with various reaction times. $\mathrm{CO}_{2}: \mathrm{F}_{2}=76 \mathrm{kPa}: 76 \mathrm{kPa} .(\bigcirc) \mathrm{CF}_{2} \mathrm{O},(\triangle)$ $\mathrm{CF}_{3} \mathrm{OF},(\square) \mathrm{CF}_{4},(\diamond) \mathrm{CF}_{3} \mathrm{OOCF}_{3}$ and $(\times) \mathrm{CF}_{2}(\mathrm{OF})_{2}$

Fig. 2.1. Randles equivalent circuit and electric components

Fig. 2.2. Cole-Cole plot for Randles equivalent circuit

Fig. 2.3. Concept of the frequency response analyzer

Fig. 2.4. Schematic illustration of the original designed cell

Fig. 2.5. Schematic diagram of the $\mathrm{CO}_{2} / \mathrm{F}_{2}$ electrochemical cell 
Fig. 2.6. Schematic diagram of original line for electromotive force measurement. (1) $\mathrm{CO}_{2}$ gas storage, (2) $\mathrm{CO}_{2}$ gas cylinder, (3) $\mathrm{F}_{2}$ gas storage, (4) $\mathrm{F}_{2}$ gas cylinder, (5) cell for electromotive force, (6) $\mathrm{F}_{2}$ gas pressure gauge, (7) $\mathrm{F}_{2}$ gas pressure digital gauge, (8) $\mathrm{CO}_{2}$ gas pressure gauge, (9) $\mathrm{F}_{2}$ gas pressure gauge, (10) PIRANI gauge, (11) Ar gas cylinder, (12) gas sampler, (13) trap (liq. $\mathrm{N}_{2}$ ), (14) vacuum pump (oil rotary), and (15) activated alumina

Fig. 2.7. XRD profiles of $\mathrm{PbSnF}_{4}$ prepared at $273 \mathrm{~K}$ (a), $298 \mathrm{~K}$ (b) and $333 \mathrm{~K}(\mathrm{c})$, and reference (d)

Fig. 2.8. Rietveld refinement profile of $\mathrm{PbSnF}_{4}$. (-: calculated, observed, $\bigcirc$ : difference), $R_{\mathrm{F}}=7.09, S=9.1397$

Fig. 2.9. Unit lattice of tetragonal $\mathrm{PbSnF}_{4} . a_{0}=0.4217 \mathrm{~nm}, c_{0}=1.1427$ $\mathrm{nm}$, Space group P4 / $\mathrm{nmm}$

Fig. 2.10. Cole-Cole plot of tetragonal $\mathrm{PbSnF}_{4}$ in air between $1 \mathrm{~Hz}$ and $500 \mathrm{kHz}$ at $323 \mathrm{~K}$. Sample thickness $=1 \mathrm{~mm}$

Fig. 2.11. Electrical conductivity of tetragonal $\mathrm{PbSnF}_{4}$ upon cooling from $473 \mathrm{~K}$ to $286 \mathrm{~K}$. (a) In air ( ), (b) in vacuum (ם), (c) in $\operatorname{Ar}(\mathbf{O})$ and in $\operatorname{Ar}$ flow ( $\mathbf{\Delta})$, and reference values (d) $(\bigcirc)$

Fig. 2.12. Chronoamperometry for $\mathrm{PbSnF}_{4}$ at $373 \mathrm{~K}$. Applied p.d. $=0.5$ $\mathrm{V}(\mathrm{a}), 0.1 \mathrm{~V}(\mathrm{~b})$. Sample thickness $=1 \mathrm{~mm}$

Fig. 2.13. The change in emf over time. Anode gas was $0.1 \mathrm{MPa} \mathrm{CO}_{2}$ and cathode gas was $\chi \mathrm{MPa} \mathrm{F}_{2}+(0.1-\chi) \operatorname{MPa} \operatorname{Ar} .(\mathbf{O}: \chi=0.02$, $\triangle: \chi=0.01)$ 
Fig. 2.14. Cole-Cole plot of tetragonal $\mathrm{PbSnF}_{4}$ between $1 \mathrm{~Hz}$ and 500

$\mathrm{kHz}$ at $373 \mathrm{~K}$. (a) Anode and cathode gases were Ar, (b) anode gas was $\mathrm{Ar}$, cathode gas was $\mathrm{F}_{2}$ gas 


\section{List of Tables}

Table 1.1. Some properties of the halogens

Table 1.2. Free energy data for halogens

Table 1.3. Yields of the products

Table 1.4. Formation rate of $\mathrm{COF}_{2}$ and rate constant and activation energy of $\mathrm{COF}_{2}$ formation

Table 2.1. Parameters for preparing $\mathrm{PbSnF}_{4}$ in this study

Table 2.2. Atomic parameter by Rietveld analysis of $\mathrm{PbSnF}_{4}$

Table 2.3. Interatomic distance by Rietveld analysis of $\mathrm{PbSnF}_{4}$

Table 2.4. Conductivities taken by electron and hole, $\sigma_{\mathrm{e}}$ and $\sigma_{\mathrm{h}}$ in

$\mathrm{PbSnF}_{4}$ at 423 and $373 \mathrm{~K}$

Scheme 1. The energy cycle with $\mathrm{CO}_{2}$ fixing process

Scheme 2. Scheme of competitive reaction processes. Blanketed compounds are the possible intermediates

Scheme 3. Some components of electrochemical impedance measurement for solid electrolyte 


\section{General Introduction}

\section{Global warming}

In recent years, global warming has caused by the increase in concentration of carbon dioxide $\left(\mathrm{CO}_{2}\right)$ by consumption of fossil fuel and desertification with deforesting etc $[1,2]$.

Many chemical compounds found in the earth's atmosphere act as "greenhouse gases". When sunlight reaches the surface of the earth, some of the energy of the sunlight is reflected back towards space as infrared radiation (heat). Greenhouse gases absorb this infrared radiation and trap the heat in the atmosphere. This absorption causes the global warming.

The major natural greenhouse gases are water vapor, which causes about $36-70 \%$ of the greenhouse effect on Earth; carbon dioxide, which causes about 9-26\%; methane, which causes about 4-9\%, and ozone, which causes about 9-26\% [3, 26-29]. The concentrations of several important greenhouse gases such as $\mathrm{CO}_{2}$ have increased by about $25 \%$ since large-scale industrialization began around 150 years ago [4, 30-32]. The temperature of the atmosphere is climbing about 1.2 to $1.4^{\circ} \mathrm{C}$ since 1900 .

Up to now, carbon dioxide has not been considered to be the important carbon resource so that the investigation about it has not been carried out enough. However, recently, from the point of view of the global environmental protection, many projects have been promoted from view of the possibility of recycling $\mathrm{CO}_{2}$. 
For this problem, the investigation on catalytic hydrogenation of carbon dioxide became important. It is examined to fix carbon dioxide by the photosynthesis due to plants and to synthesize methyl alcohol by hydrogen addition $[5,6]$. These processes are based on the concept that carbon dioxide is final products of combustion. This is, carbon dioxide must be reduced by hydrogen to convert into methyl alcohol and hydrocarbon etc. Collected carbon dioxide reacts with hydrogen under the existence of a catalyst. It is converted to methyl alcohol and hydrocarbon etc., which can be used as a fuel.

The main reactions are shown as follows.

$$
\begin{aligned}
& \mathrm{CO}_{2}+3 \mathrm{H}_{2} \rightarrow \mathrm{CH}_{3} \mathrm{OH}+\mathrm{H}_{2} \mathrm{O} \\
& \mathrm{CO}_{2}+4 \mathrm{H}_{2} \rightarrow \mathrm{CH}_{4}+2 \mathrm{H}_{2} \mathrm{O}
\end{aligned}
$$

The investigation on methyl alcohol synthesis is carried out most actively in the field of the catalytic hydrogenation of carbon dioxide. According to the report by T. Inui et al [7], they developed the $\mathrm{Cu}-\mathrm{Zn}-\mathrm{Cr}-\mathrm{Al}_{2} \mathrm{O}_{3}$ catalyst with very high activity. When $\mathrm{Pb}$ and $\mathrm{Ag}$ were added to $\mathrm{Cu}-\mathrm{Zn}-\mathrm{Cr}-\mathrm{Al}_{2} \mathrm{O}_{3}$ catalyst, the conversion ratio from carbon dioxide to methyl alcohol became $22.1 \%$ at $523 \mathrm{~K}, 50 \mathrm{~atm}$.

In the catalytic hydrogenation of carbon dioxide, methane is the main product. According to the report by T. Inui et al [8], in methanation of carbon dioxide, they developed the catalyst of $\mathrm{Ni}-\mathrm{Ru}-\mathrm{La}_{2} \mathrm{O}_{3}$ system. In this case, the conversion ratio of carbon dioxide became $100 \%$ at $523 \mathrm{~K}$.

\section{Reaction between $\mathrm{CO}_{2}$ and $\mathrm{F}_{2}$}

From the point of view concerning to fluorine chemistry, what can be done to contribute to the carbon dioxide fixation? The elementary fluorine has the strongest 
oxidizing ability $\left(E_{0}=2.87 \mathrm{~V}\right)$ among all elements and it is only the element that can oxidize the oxides $[9,10]$. For instance, alumina is one of the most stable oxides. But even the alumina is fluorinated with heat radiation, and oxygen is isolated.

Using elementary fluorine, the energy cycle in which carbon dioxide is used as a fuel will be able to propose. One example of this new energy cycle including the reaction between $\mathrm{CO}_{2}$ and $\mathrm{F}_{2}$ is shown in scheme 1.

First, $\mathrm{CO}_{2}$ is converted to $\mathrm{COF}_{2}$ by the reaction between $\mathrm{CO}_{2}$ and $\mathrm{F}_{2}$. During this process, $\mathrm{O}_{2}$ and the energy may be generated [11]. Next, $\mathrm{COF}_{2}$ is used to produce the carbonate compound as a reagent of organic synthesis with alcohols, thereby producing HF. The HF is converted into fluorine gas by electrolysis. Hydrogen gas is a by-product here. The solar energy can be used for this electrolysis and hydrogen is also the one of the key-fuel for the energy in the future.

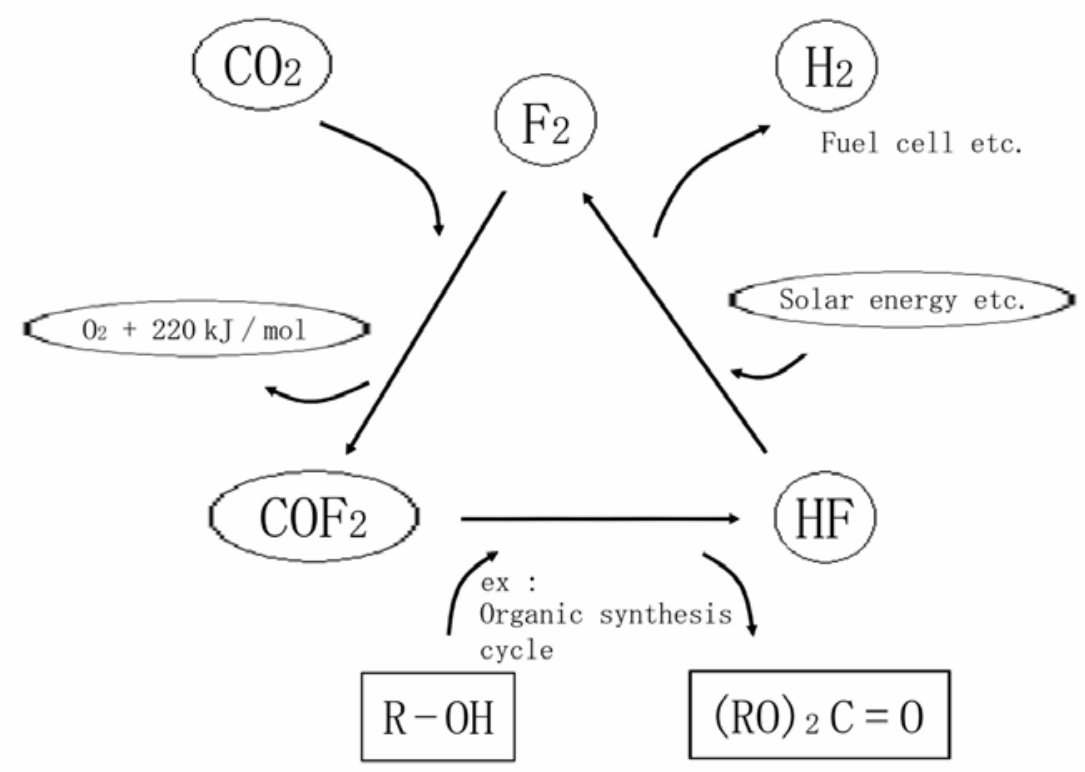

Scheme 1 . The energy cycle with $\mathrm{CO}_{2}$ fixing process. 
The reaction between $\mathrm{CO}_{2}$ and $\mathrm{F}_{2}$ to form $\mathrm{COF}_{2}$ must take place spontaneously even at room temperature because the Gibbs free energy change of the reaction is calculated as $-220 \mathrm{~kJ} \mathrm{~mol}^{-1}[11]$.

$$
\mathrm{CO}_{2}+\mathrm{F}_{2} \rightarrow \mathrm{COF}_{2}+1 / 2 \mathrm{O}_{2}+(-\Delta \mathrm{G}) 220 \mathrm{~kJ} \mathrm{~mol}^{-1}
$$

The theoretical electromotive force calculated from its Gibbs free energy is $1.14 \mathrm{~V}$, which value is mostly equal to the electromotive force $1.23 \mathrm{~V}$ of the $\mathrm{H}_{2} / \mathrm{O}_{2}$ fuel cell [12, $13]$.

There has been no investigation based on this concept. In order to examine the possibility of establishment of this energy cycle including the $\mathrm{CO}_{2} / \mathrm{F}_{2}$ fuel cell for fixation of $\mathrm{CO}_{2}$, at first, a safe apparatus in which the reaction took place is constructed.

We have tried to examine the $\mathrm{CO}_{2} / \mathrm{F}_{2}$ electrochemical cell with $\mathrm{PbSnF}_{4}$ as one device for the fixation of $\mathrm{CO}_{2}$. At same time, this cell is a device that converts the chemical energy of the reaction between $\mathrm{CO}_{2}$ and $\mathrm{F}_{2}$ into electrical energy.

Tetragonal $\mathrm{PbSnF}_{4}$ [14-18] is known as a fluoride ion conductor having high electric conductivity at ambient temperatures, and $\mathrm{PbSnF}_{4}$ has been used for the design of chemical sensors, and operated as oxygen sensors [19-21] from room temperature up to $523 \mathrm{~K}$.

$\mathrm{COF}_{2}$ has not been used for the variety of applications. However, during the last three decades, carbonyl fluoride $\left(\mathrm{COF}_{2}\right)$ plays a key role in both atmospheric and plasma etching chemistry and flame suppression behavior of fluorocarbons. $\mathrm{COF}_{2}$ and fluorooxomethyl radical $\left(\mathrm{FCO}^{\circ}\right)$ are important intermediates $[22,23]$ in the oxidative degradation of many fluorinated compounds. These species are involved in the mechanism of flame suppression by the fluorinated compounds. These species are also formed in the fluorocarbon / oxygen plasma used in many etching processes. 
Perfluorocompounds (PFCs) are mainly used as the etching gas for the etching process and as the cleaning gas of chemical vapor deposition chamber in semiconductor manufacturing. It is reported that PFCs have large effect on global warming by the greenhouse effect, because they have very long atmospheric lifetimes. Many governments of the world decided to conclude the Kyoto Protocol [33]. Japan will be obliged to reduce greenhouse gases by $6 \%$ compared to the base year of 1990 . Numerous studies have been performed on reducing PFCs emissions. The development of several gases, such as $\mathrm{COF}_{2}$ and $\mathrm{F}_{2}$, has shown promising results. Many semiconductor companies have been adopted $\mathrm{COF}_{2}$ in terms of reducing the global warming impact. $\mathrm{COF}_{2}$ has a small global warming potential, because hydrolysis proceeds rapidly, even in the atmosphere, to give $\mathrm{CO}_{2}$ and $\mathrm{HF}$.

\section{Objective of this study}

This study reports the reaction between carbon dioxide and elementary fluorine [24, 25]. The main objective of studying this reaction was to construct the $\mathrm{CO}_{2} / \mathrm{F}_{2}$ electrochemical cell with $\mathrm{PbSnF}_{4}$ as one of the methods for the fixation of $\mathrm{CO}_{2}$.

This study consists of 3 chapters. Chapter 1 is directly concerned with the reaction between $\mathrm{CO}_{2}$ and $\mathrm{F}_{2}$ as an approach to a $\mathrm{CO}_{2} / \mathrm{F}_{2}$ fuel cell. The properties of fluorine, the reactions with $\mathrm{CO}_{2}$ and the concept of new energy cycle are described in Chapter 1.1 as introduction. The experimental method such as the construction of reaction apparatus, experimental procedure, and analysis of products are presented in Chapter 1.2. Results and discussion are presented in Chapter 1.3.

In chapter 2 based upon the results in chapter 1, the $\mathrm{CO}_{2} / \mathrm{F}_{2}$ electrochemical cell as the device for the fixation of $\mathrm{CO}_{2}$ was reviewed. The chapter 2.1 consists of a theory and 
the device as the $\mathrm{CO}_{2} / \mathrm{F}_{2}$ fuel cell. The preparation of $\mathrm{PbSnF}_{4}$ as the solid electrolyte, experimental procedures, analysis of products, and the construction of electrochemical cell as one of the methods for the fixation of $\mathrm{CO}_{2}$ are presented in Chapter 2.2. The structure and electrochemical properties of tetragonal $\mathrm{PbSnF}_{4}$, and an electrochemical cell performance are discussed in Chapter 2.3. The measurement of electron motive force, the preparation of $\mathrm{COF}_{2}$ in a $\mathrm{CO}_{2} / \mathrm{F}_{2}$ electrochemical cell, and its results were mentioned.

Finally, conclusions and future work are presented in Chapter 3.

\section{References and Notes}

[1] Iwao Omae, Nisankatannso to Tikyukankyou, Tyukousinnsho (1999) pp. 23-142. http://cdiac.esd.ornl.gov/trens/emis/em_cont.htm.

[2] J. Houghton, Grobal Warming: The Complete Briefing, Cambridge University Press, New York, NY (1997).

[3] P. M. Vitousek, Ecology 75 (1994) 1861-1876.

[4] IPCC Third Assessment Report: Climate Change 2001.

[5] Y. Matsumoto, M. Obata, and J. Hombo, J. Phys. Chem. 98 (1994) 2950-2951.

[6] W. M. Sears and S. R. Morrison, J. Phys. Chem. 89 (1985) 3295-3298.

[7] T. Inui, T. Takeguchi, Catal. Today 10 (1991) 95-106.

[8] T. Inui, M. Funabiki, Y. Sezume, J. Chem. Soc. Faraday Trans 175 (1979) 787-802.

[9] P. Politzer, J. Am. Chem. Soc. 91 (1969) 6235-6237.

[10] The Entrance of Fluorine Chemistry, 155 Committee of Fluorine Chemistry. (Printed in Japan, 1999)

[11] J. C. Amphlett, J. R. Dacey, G. O. Pritchard, J. Phys. Chem. 75 (1971) 3024-3026. 
[12] Gregor Hoogers, Fuel Cell Technology Handbook (CRC press, 2003).

[13] W. M. Latimer, The Oxidation States of the Elements and Their Potentials in Aqueous Solutions (Prentice Hall, New York, 1952).

[14] D. J. Donaldson, B. J. Senior, J. Chem. Soc. (A) 1821-1825 (1967).

[15] J. M. Reau, C. Lucat, J. Portior, P. Hagenmuller, L. Cot, S. Vilminot, Mat. Res. Bull. $13(1978) 877-882$.

[16] J. Pannetier, G. Denes, J. Lucas, Mat. Res. Bull. 14 (1979) 627-631.

[17] G. Perez, S. Vimont, W. Granier, L. Cot, C. Lucat, J. M. Reau, J. Portior, P. Hagenmuller, Mat. Res. Bull. 15 (1980) 587-593.

[18] G. Denes, M. C. Madamda, A. Muntasar, A. Peroutka, K. Tam, and Z. Zhu, Nato, Sci. Ser. 25-38 (1999).

[19] A. Wakagi, J. Kuwano, Y. Saito, J. Mat. Chem. 41 (1994) 973-975.

[20] T. Eguti, S. Suda,T. Hijii, S. Koga, J. Kuwano, Y. Saito, Key Engineering Materials. 181-182 (2000) 199-202.

[21] A. Wakagi, J. Kuwano, M. Kato, H. Hanamoto, Solid State Ionics, 70-71 (1994) $601-605$.

[22] M. R. Zachariah, W. Tsang, P. R. Westmoreland, D. R. F. Burgess, J. Phys. Chem. 99 (1995) 12512-12519.

[23] T. J. Burckley, R. D. Johson, R. E. Hule, Z. Zhang, S. C. Kuo, and R. B. Klemm, J. Phys. Chem. 99 (1995) 4879-4885.

[24] Yasuo Hasegawa, Reiko Otani, Susumu Yonezawa, Masayuki Takashima, J. Fluorine Chem. 128 (2007) 17-28.

[25] Yasuo Hasegawa, Akitomo Nagasaka, Jae-Ho Kim, Susumu Yonezawa, Masayuki Takashima, J. Fluorine Chem. 128 (2007) 958-964. 


\section{Hp Reference site on the internet}

[26] http://www.epa.gov/airmakets/climtchg/index.html.

[27] http://yosemite.epa.gov/org/globalwarming.nsf/content/emissions.html.

[28] http://www.atmo.arizona.edu/students/courselinks/spring04/atmo451b/pdf/ Radiation Budget.pdf.

[29] http://www.realclimate.org/index.php?p-142.

[30] http://www.eia.doe.gov/oiaf/1605/ggccebro/chapter1.htlm

[31] http://www.grida.no/climate/ipcc_tar/wg1/016.htm.

[32] http://www.grida.no/climate/ipcc_tar/wg1/fig6-6.htm.

[33] http://www.runfccc.de/index.html. 


\section{Chapter 1}

\section{Reaction between carbon dioxide and elementary fluorine}

\subsection{Introduction}

The reaction between $\mathrm{CO}_{2}$ and $\mathrm{F}_{2}$ to form $\mathrm{COF}_{2}$ takes place spontaneously even at room temperature because the Gibbs free energy change of the reaction is calculated as $220 \mathrm{~kJ} \mathrm{~mol}^{-1}[1]$.

$$
\mathrm{CO}_{2}+\mathrm{F}_{2} \rightarrow \mathrm{COF}_{2}+1 / 2 \mathrm{O}_{2}+(-\Delta \mathrm{G}) 220 \mathrm{~kJ} \mathrm{~mol}^{-1}
$$

Some reports have addressed preparation of $\mathrm{COF}_{2}[2,3]$ and $\mathrm{CF}_{3} \mathrm{OF}[2]$ from $\mathrm{CO}$ and $\mathrm{F}_{2}$; few reports have examined the reaction between $\mathrm{CO}_{2}$ and $\mathrm{F}_{2}$. Only three reports have described formation not of $\mathrm{COF}_{2}$, but of $\mathrm{CF}_{2}(\mathrm{OF})_{2}$, using $\mathrm{CsF}$ as a catalyst [4-6]. To confirm the conversion of $\mathrm{CO}_{2}$ into $\mathrm{COF}_{2}$, the reaction between $\mathrm{CO}_{2}$ and $\mathrm{F}_{2}$ has been tried at various temperatures from 303 to $523 \mathrm{~K}$ under various pressure and mixing ratios of both gases. This reaction was carried out similarly in the presence of $\mathrm{NaF}, \mathrm{CsF}$ and $\mathrm{EuF}_{3}$. Catalytic abilities of these metal fluorides to form $\mathrm{COF}_{2}$ were examined. In addition, the reaction mechanism and reaction rate are discussed in this paper. 


\subsubsection{Properties of fluorine}

Although the chemistry of the halogens is somewhat complex, similarities within the group are more pronounced than in any of the other groups. The elements, fluorine, chlorine, bromine, iodine, and astatine, are collectively called halogens, or salt producers, because they all have high electronegativity $(\mathrm{F}=4.0, \mathrm{Cl}=3.0, \mathrm{Br}=2.8, \mathrm{I}=2.5)$ and form negative halide ions such as ionic salts. Except for fluorine, they also show positive oxidation states. Because of their high electronegativity, the halogens show practically no metallic properties. Fluorine has the largest electronegativity of all the elements. Therefore, it can show only a negative oxidation state. The other halogens show positive oxidation states in compounds with more electronegative elements.

Fluorine $[7,8]$ exhibits a number of anomalous properties, both as an atom and as a molecule. Some properties of the group are shown in table 1.1. As indicated by the relatively high values of the ionization potentials, it is fairly difficult to remove an electron from a halogen atom. Within the group from $\mathrm{F}_{2}$ to $\mathrm{I}_{2}$, there is a decrease in the ionization potentials.

Table 1.1

Some properties of the halogens

\begin{tabular}{|c|c|c|c|c|c|c|c|}
\hline Halogen & $\begin{array}{c}\text { Melting } \\
\text { point } \\
{ }^{\circ} \mathrm{C}\end{array}$ & $\begin{array}{c}\text { Boiling } \\
\text { point } \\
{ }^{\circ} \mathrm{C}\end{array}$ & $\begin{array}{c}\text { Ionaization } \\
\text { potential } \\
\mathrm{eV}\end{array}$ & $\begin{array}{c}\text { Electron } \\
\text { affinity } \\
\text { eV }\end{array}$ & $\begin{array}{c}\text { Atomic } \\
\text { radius } \\
\AA\end{array}$ & $\begin{array}{c}\text { Oxidation } \\
\text { potential } \\
\text { volts } \\
\left(\mathrm{X}^{-} \text {to } \mathrm{X}_{2}\right) \\
\end{array}$ & $\begin{array}{c}\text { Dissosiation } \\
\text { energy of } \\
\text { molecule } \\
\text { kcal mol }^{-1}\end{array}$ \\
\hline $\mathrm{F}$ & -223 & -187 & 17.42 & 3.448 & 0.5741 & -2.87 & 37 \\
\hline $\mathrm{Cl}$ & -102 & -34.6 & 13.01 & 3.613 & 0.9748 & -1.36 & 57.88 \\
\hline $\mathrm{Br}$ & -7.3 & 58.78 & 11.84 & 3.363 & 1.0117 & -1.09 & 45.92 \\
\hline I & 114 & 183 & 10.44 & 3.063 & 1.324 & -0.54 & 35.86 \\
\hline
\end{tabular}


The ionization potentials show the monotonic increase in going from iodine to fluorine. The electron affinities of iodine, bromine, and chlorine also increase gradually. In fact, there is a liner correlation between ionization potential and electron affinity for these three elements. The electron affinity of fluorine deviates very markedly from the general trend, and it is less than that of chlorine. This deviation can be obtained by extrapolating the liner relationship to the ionization potential of fluorine. It corresponds to an electron affinity of $4.59 \mathrm{eV}$, which is $1.14 \mathrm{eV}\left(26.3 \mathrm{kcal} \mathrm{mol}^{-1}\right)$ greater than the true value. Thus, the electron affinity of fluorine is estimated to be $1.14 \mathrm{eV}$ greater than the true value.

Apparently, the formation of the fluoride ion includes an unusual destabilizing effect corresponding to about $26.3 \mathrm{kcal} \mathrm{mol}^{-1}$. For example, there should be observed a corresponding lowering of the bond energies of the metal fluoride.

The metal fluorides are considered to be ionic, and the bond energies of the fluorides are consistently lower about $26.3 \mathrm{kcal} \mathrm{mol}^{-1}$ among the other halides. The dissociation energy of $\mathrm{F}_{2}$ is very low, relative to the trend among the other halogen molecules.

Although the bond between the halogen atoms in the $\mathrm{X}_{2}$ molecules is fairly strong as shown in table 1.2 , the attraction between $\mathrm{X}_{2}$ molecules is quite weak and due only to van der Waals forces. It would be expected van der Waals attraction to increase with increasing number of electrons per $\mathrm{X}_{2}$ molecules. Thus, the boiling points increase in going from $\mathrm{F}_{2}$ to $\mathrm{I}_{2}$.

The oxidation potentials are greatly significant. The potentials show that fluorine gas is the best oxidizing agent of the group. The reason for this is not so simple as it appears. The overall half-reaction can be constructed from the alternate path:

$$
\mathrm{X}^{-}(a q) \rightarrow 1 / 2 \mathrm{X}_{2}(g)+\mathrm{e}^{-}
$$




$$
\mathrm{X}^{-}(\mathrm{aq}) \rightarrow \mathrm{X}^{-}(g) \rightarrow \mathrm{X}(g)+\mathrm{e}^{-} \rightarrow 1 / 2 \mathrm{X}_{2}(g)+\mathrm{e}^{-}
$$

The free energy changes for various steps are listed in table 1.2. In the case of fluorine, the sum of the three processes shown has a net free energy change of $+182 \mathrm{kcal}$ for $\mathrm{X}^{-}(a q) \rightarrow 1 / 2 \mathrm{X}_{2}(g)+\mathrm{e}^{-}$. The electron is referred to a hydrogen electrode standard, which amounts to having a change of - $115 \mathrm{kcal}$ in the free energy.

$$
\mathrm{X}^{-}(\mathrm{aq})+\mathrm{H}^{+} \rightarrow 1 / 2 \mathrm{X}_{2}(g)+1 / 2 \mathrm{H}_{2}(g)+(\Delta \mathrm{G}) 67 \mathrm{kcal} \mathrm{mol}^{-1}
$$

By using the relation $\Delta \mathrm{G}^{\circ}=-n F E^{\circ}$, the calculated oxidation potential for fluorine is 2.87 volts.

Table 1.2

Free energy data for halogens $\left(\mathrm{kcal} \mathrm{mol}^{-1}\right)$

\begin{tabular}{ccccc}
\hline Step & Fluorine & Chlorine & Bromine & Iodine \\
\hline $\mathrm{X}^{-}(a q) \rightarrow \mathrm{X}^{-}(g)$ & 114 & 84 & 78 & 70 \\
$\mathrm{X}^{-}(g) \rightarrow \mathrm{X}(g)+\mathrm{e}^{-}$ & 83 & 86 & 81 & 74 \\
$\mathrm{X}(g) \rightarrow 1 / 2 \mathrm{X}_{2}(g)$ & -15 & -25 & -19 & -14 \\
\hline
\end{tabular}

Comparing the halogens with each other, there is a large increase in ionic radius (1.33 $\AA$ for $\mathrm{F}^{-}, 1.81 \AA$ for $\mathrm{Cl}^{-}, 1.96 \AA$ for $\mathrm{Br}^{-}$, and $2.20 \AA$ for $\mathrm{I}^{-}$) from $\mathrm{F}^{-}$to $\mathrm{I}^{-}$. The reason why $\mathrm{F}_{2}$ is a good oxidizing and reactive agent is that the fluoride ion is so small such as hydrogen. The smaller size of the fluoride ion leads to more favorable lattice energies.

The fields of fluorine chemistry lie at the boundary between organic and inorganic chemistry. Inorganic fluorine chemistry is concerned with the productions and the 
reactions of a wide variety of volatile and nonvolatile inorganic compounds which are prepared through various fluorination processes. Some of these fluorinated inorganic compounds have been used often as fluorinating reagents. Most volatile inorganic fluorides are prepared with using elemental fluorine, either directly or through the reactions with fluorinating reagents such as $\mathrm{ClF}_{3}$. The strong tendency of inorganic fluorides to form salts, complexes, and coordination compounds leads to a wide variety of nonvolatile inorganic fluorine compounds.

\subsubsection{New energy cycle with $\mathrm{CO}_{2}$ fixing process}

A strong oxidant, $\mathrm{F}_{2}$ can oxidize the oxides. Previously, we have reported a reaction between $\mathrm{CO}_{2}$ and $\mathrm{F}_{2}$ to form $\mathrm{COF}_{2}$ [9-11]. By this reaction, $\mathrm{CO}_{2}$ can be converted to $\mathrm{COF}_{2}$. The Gibbs free energy change of this reaction is calculated as $-220 \mathrm{~kJ} \mathrm{~mol}^{-1}$ [1]. Furthermore, the theoretical electromotive force calculated from its Gibbs free energy is $1.14 \mathrm{~V}$, which value is mostly equal to the electromotive force $1.23 \mathrm{~V}$ of the $\mathrm{H}_{2} / \mathrm{O}_{2}$ fuel cell $[12,13]$.

As described above, we proposed one example of this new energy cycle including the reaction between $\mathrm{CO}_{2}$ and $\mathrm{F}_{2}$ in scheme 1.

To complete this cycle, the reaction between $\mathrm{CO}_{2}$ and $\mathrm{F}_{2}$ must be investigated in detail. Finally, based on this idea, we tried to investigate $\mathrm{COF}_{2}$ formation using $\mathrm{CO}_{2}$ and $\mathrm{F}_{2}$ in the electrochemical cell with $\mathrm{PbSnF}_{4}$ as one method for $\mathrm{CO}_{2}$ fixation. 


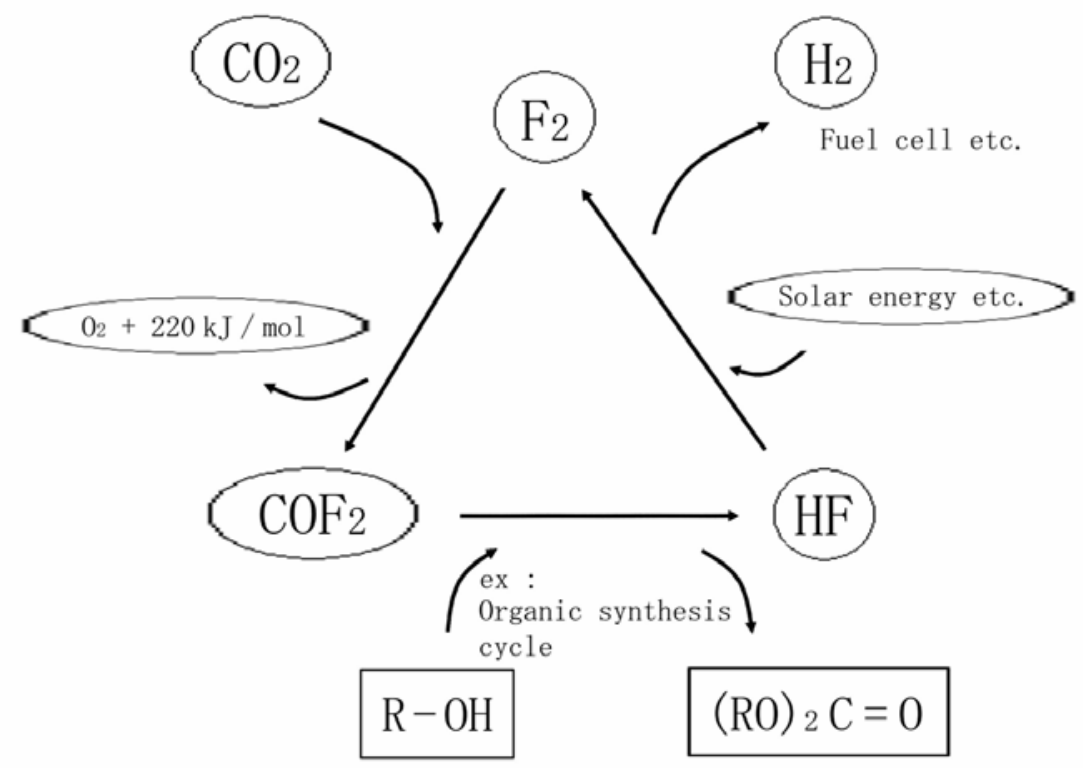

Scheme 1. The energy cycle with $\mathrm{CO}_{2}$ fixing process.

\subsection{Experimental}

Fig. 1.1 shows a gas line made of SUS $316 \mathrm{~L}$ for the reaction between $\mathrm{CO}_{2}$ and $\mathrm{F}_{2}$, which was originally designed to control and monitor reaction pressures and temperatures precisely. This apparatus has three separate parts: a gas-gas reaction line, a trap-to-trap separation line, and a vacuum line.

The reactor was filled with $\mathrm{F}_{2}$ gas at $20 \mathrm{kPa}$; it was kept at $523 \mathrm{~K}$ for one day to passivate the inner wall of the line before use. The $\mathrm{F}_{2}$ gas in the exhaust was eliminated by passing it through the activated alumina column. The reactor vessel capacities were $59.6 \mathrm{ml}$. The amount of $\mathrm{F}_{2}$ gas that was fixed to the activated alumina was about 300 $\mathrm{dm}^{3} / 450 \mathrm{~g} \mathrm{Al}_{2} \mathrm{O}_{3}$.

The $\mathrm{CO}_{2}$ was introduced into the reactor and the reactor was cooled to $77 \mathrm{~K}$ (liquid 
$\mathrm{N}_{2}$ ). Then, $\mathrm{F}_{2}$ gas was introduced into the reactor. The reaction temperature was controlled at $303-523 \mathrm{~K}$. Residual $\mathrm{F}_{2}$ in the product was eliminated by vaporization at 77 K.

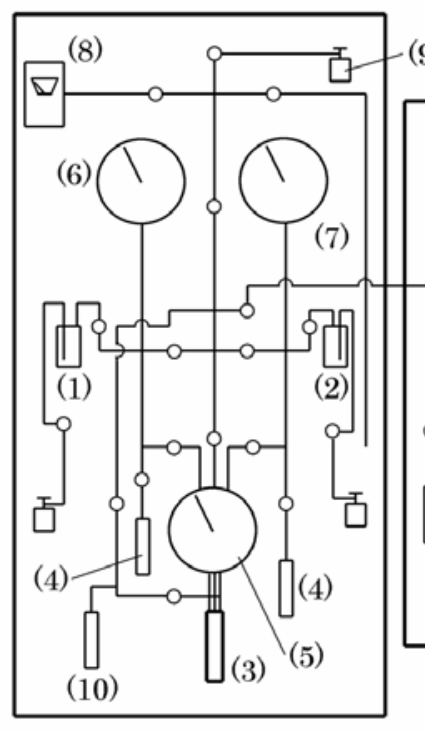

(a)

(9)

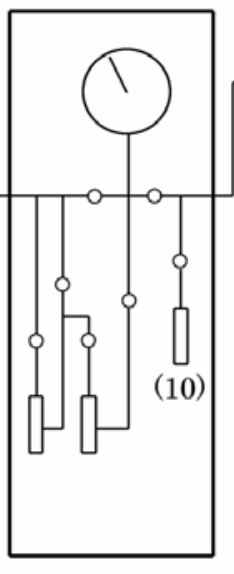

(b)

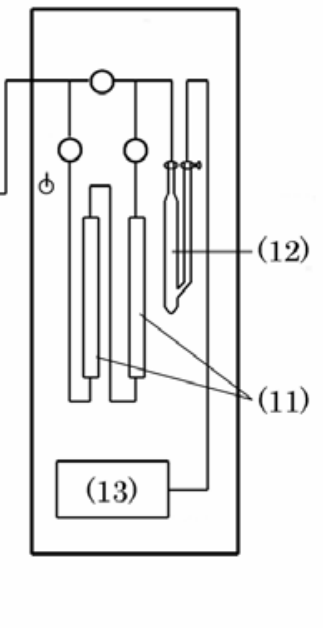

(c)

Fig. 1.1. Apparatus for the reaction between $\mathrm{CO}_{2}$ and $\mathrm{F}_{2}$. (a) Gas-gas reaction line, (b) trap-to-trap separation line and (c) vacuum line. (1) $\mathrm{CO}_{2}$ gas storage, (2) $\mathrm{F}_{2}$ gas storage, (3) reactor (SUS316L), (4) constant volume container, (5) reactor pressure gauge, (6) $\mathrm{CO}_{2}$ gas pressure gauge, (7) $\mathrm{F}_{2}$ gas pressure gauge, (8) PIRANI gauge, (9) Ar or He gas cylinder, (10) gas sampler, (11) activated alumina, (12) trap (liquid $\mathrm{N}_{2}$ ), and (13) vacuum pump (oil rotary).

For the reaction with the metal fluorides, the metal fluoride (1 equiv. mol or $3 \mathrm{~g}$ ) was 
first put into a nickel container. Before use, the metal fluorides were kept all through the night in $\mathrm{F}_{2}$ gas at $503 \mathrm{~K}$ to eliminate trace amounts of water and oxides.

After mixing $\mathrm{CO}_{2}$ and $\mathrm{F}_{2}$, the temperature at the surface of the reactor was measured. The relation between the lapse of time and pressure change was measured to monitor the reaction progress. The total pressure was fixed at $152 \mathrm{kPa}$.

The reaction product after eliminating $\mathrm{F}_{2}$ was introduced into the $10 \mathrm{~cm}$ path length IR cell having $\mathrm{BaF}_{2}$ or $\mathrm{CaF}_{2}$ window at $2 \mathrm{kPa}$ or $0.4 \mathrm{kPa}$ (FT-IR $8960 \mathrm{PC}$; Shimadzu Corp.). Moreover, the product was analyzed by GC / FT-IR (Nexus; Thermo Nicolet Japan Inc.) with a sample amount $20 \mu \mathrm{l}$, split-less and GC / EI-MS, CI-MS: for EI ( 6890 / 5970 GC / MDS; Hewlett Packard Co.), $m / z$ 15-300, with a sample amount $20 \mu \mathrm{l}$, splitless; for CI with methane, (QP 5000A; Shimadzu Corp.), $\mathrm{m} / z$ 45-300, with a sample amount $1 \mathrm{ml}$, split). The capillary column for the GC was $100 \mathrm{~m}$ (for GC / FT-IR, $200 \mathrm{~m}$ ) $\times 0.25 \mathrm{~mm} \times 0.5 \mu \mathrm{m}($ DB-PETRO; J\&W Scientific Inc.). The oven temperature was controlled at 223, 243 and $303 \mathrm{~K}$. Before GC / MS analysis, helium gas was introduced into the reactor so that the total pressure was set at $202.6 \mathrm{kPa}$.

The calibration line of the reaction product was prepared with IR data and MS intensity.

Fig. 1.2(a) portrays a $\mathrm{CO}_{2}$ calibration line in which the absorbance was plotted against the pressure. Into the IR cell, $\mathrm{CO}_{2}$ gas was introduced at a proper pressure; the IR spectra were measured at resolution of $4 \mathrm{~cm}^{-1}$. The absorption peak at $2360 \mathrm{~cm}^{-1}$ was chosen for the calibration line of $\mathrm{CO}_{2}$. For $\mathrm{COF}_{2}, \mathrm{CF}_{3} \mathrm{OF}, \mathrm{CF}_{2}(\mathrm{OF})_{2}$ and $\mathrm{CF}_{3} \mathrm{OOCF}_{3}$ [2], the relations between the pressure and the absorbance were referred from the literature [4, 14-19]. The calibration line was obtained by plotting the absorbance against the pressure. Fig. 1.2(b) shows the $\mathrm{COF}_{2}$ calibration line. Line 1 in Fig. 1.2(b) was drawn using the absorbance at $1930 \mathrm{~cm}^{-1}$ in the literature [17]. The corrected 
calibration line, line 2 in Fig. 1.2(b) was obtained by plotting the absorbance against the pressure measured by Central Glass Co. Ltd. [18]. The slopes of line 1 and line 2 were approximated respectively as 1803,1254 . Fig. $1.2(\mathrm{c})$ shows the $\mathrm{CF}_{3} \mathrm{OF}$ calibration line. Line 1 in Fig. 1.2(c) was drawn using the absorbance at $1282 \mathrm{~cm}^{-1}$ in the literature [19]. However, the sum of $\mathrm{CO}_{2}$ residual pressure and pressure of $\mathrm{CF}_{3} \mathrm{OF}$ was greater than 2 $\mathrm{kPa}$, which was the total pressure at the measurement, when the pressure of $\mathrm{CF}_{3} \mathrm{OF}$ was estimated using line 1 in Fig. 1.2(c). The corrected calibration line 2 was determined by considering the effect of IR spectrum resolution against line 1 . The slopes of line 1 and line 2 were respectively approximately 366,153 . The pressures evaluated using these corrected calibration lines were about $50 \%$ lower than those by calibration lines with plotting the values in the literature $[4,14-17,19]$. In this case, the resolution greatly affected the absorption intensity. Line 3 in Fig. 1.2(c) was obtained by plotting the absorbance at $945 \mathrm{~cm}^{-1}$ against the pressure. Line 3 was used instead of line 2 when the absorbance at $1282 \mathrm{~cm}^{-1}$ could not be used for the calculation.

Fig. 1.2(d) is the $\mathrm{CF}_{4}$ calibration line. This line plotted the MS intensity against concentration of $\mathrm{CF}_{4}$. The concentration of $\mathrm{CF}_{4}$ and its $\mathrm{MS}$ intensity were measured using GC / MS with the standard sample. The $\mathrm{CF}_{4}$ concentration was measured as a volume percentage of the GC injection gas. It was assumed that the MS intensities of $\mathrm{COF}_{2}$ and $\mathrm{CF}_{3} \mathrm{OOCF}_{3}$ were equal to that of $\mathrm{CF}_{4}$ to draw the calibration line of $\mathrm{COF}_{2}$ and $\mathrm{CF}_{3} \mathrm{OOCF}_{3}$. 

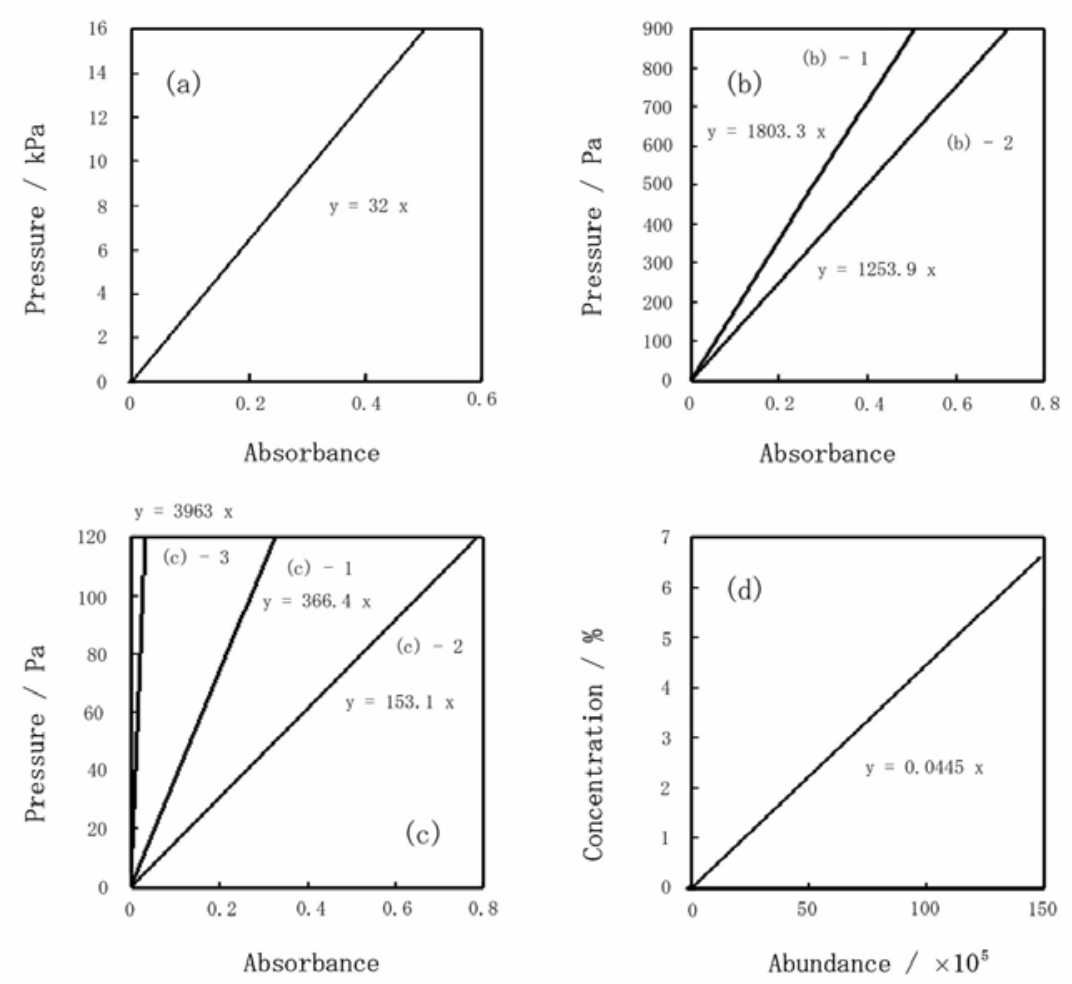

Fig. 1.2. Calibration lines of $\mathrm{CO}_{2}(\mathrm{a}), \mathrm{COF}_{2}(\mathrm{~b}), \mathrm{CF}_{3} \mathrm{OF}$ (c) and $\mathrm{CF}_{4}(\mathrm{~d})$. (b)-1 and (b) -2 correspond, respectively, to data at $1930 \mathrm{~cm}^{-1}$ in Ref. [17] and Ref. [18]. (c) -1 , (c) -2 and (c) -3 correspond to data at $1282 \mathrm{~cm}^{-1}$ in Ref. [19], at 1282 and at $945 \mathrm{~cm}^{-1}$ measured in this study.

\subsection{Results and Discussion}

\subsubsection{Reaction product}

The pressure change was observed obviously with increasing reaction time as shown in Fig. 1.3. 


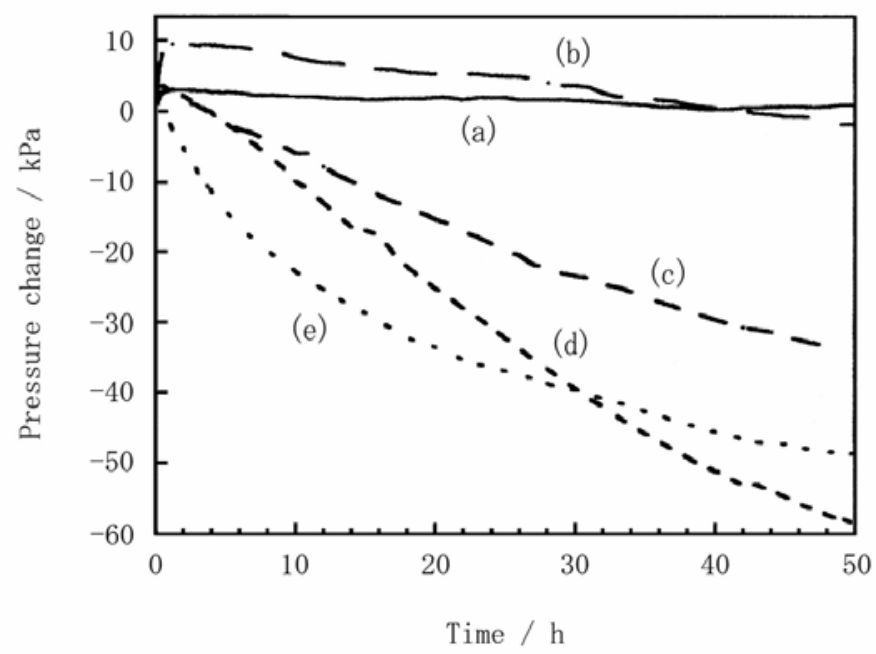

Fig. 1.3. Transient of the pressure change in the direct reactions at (a) 373 $\mathrm{K}$, (b) $423 \mathrm{~K}$, (c) $473 \mathrm{~K}$, (d) $498 \mathrm{~K}$ and (e ) $523 \mathrm{~K} . \mathrm{CO}_{2}: \mathrm{F}_{2}=50.7 \mathrm{kPa}: 101.3$ $\mathrm{kPa}$ and reaction time $50 \mathrm{~h}$.

Fig. 1.4 shows FT-IR spectra of the reaction products of the direct reaction of $\mathrm{CO}_{2}$ and $\mathrm{F}_{2}$ have many peaks. The absorption peaks corresponded to $\mathrm{O}-\mathrm{F}, \mathrm{C}-\mathrm{F}$ and $\mathrm{CF}=\mathrm{O}$ bonds that appeared respectively at $800-1000 \mathrm{~cm}^{-1}, 1200-1300 \mathrm{~cm}^{-1}$, and around $1930 \mathrm{~cm}^{-1}$. The absorption peaks at 2360 and $3700 \mathrm{~cm}^{-1}$ indicate the presence of residual $\mathrm{CO}_{2}$. Some fluorocarbon compounds, including $\mathrm{CF}_{3} \mathrm{OF}$, were inferred to have been produced.

Gram-Schmide spectra of the reaction product measured using GC / FT-IR are shown in Fig. 1.5. They confirmed that three products existed, with retention times of 18.95-18.96, 19.04-19.06 and 19.23-19.27 $\mathrm{min}$. 


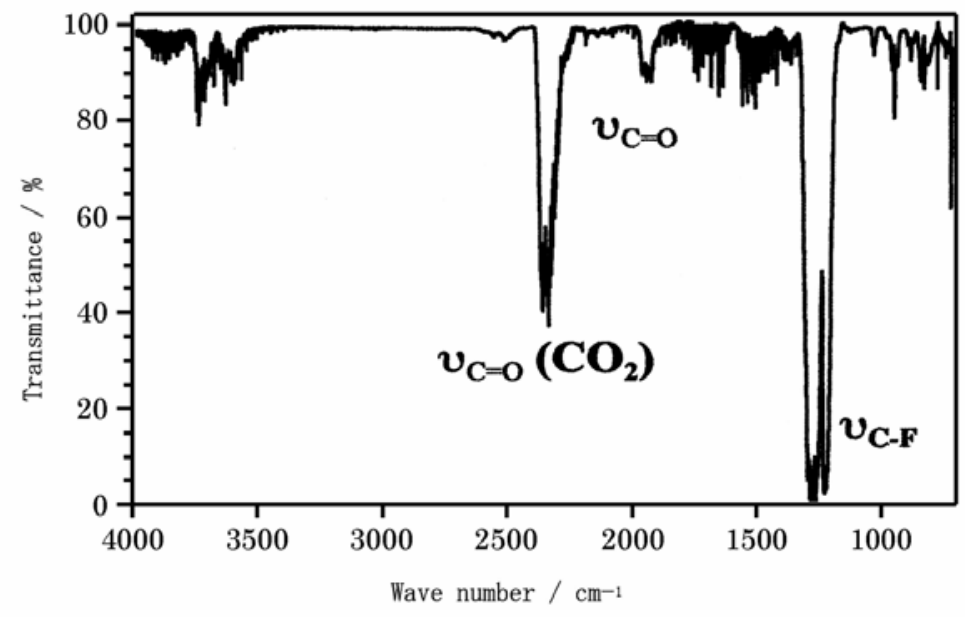

Fig. 1.4. FT-IR spectrum of the product in the direct reaction. $\mathrm{CO}_{2}: \mathrm{F}_{2}=76$ $\mathrm{kPa}: 76 \mathrm{kPa}$, reaction temp. $498 \mathrm{~K}$, and reaction time $24 \mathrm{~h}$.

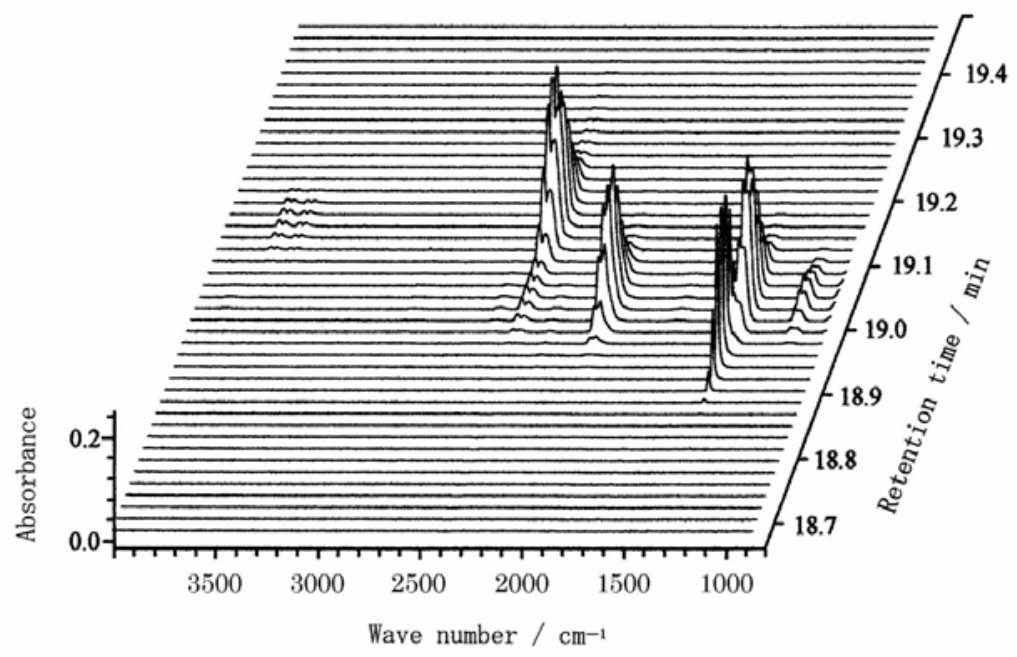

Fig. 1.5. Gram-Schmide spectra of the product measured using GC / FT-IR. $\mathrm{CO}_{2}: \mathrm{F}_{2}=50.7 \mathrm{kPa}: 101.3 \mathrm{kPa}$, reaction temp. $498 \mathrm{~K}$, and reaction time $50 \mathrm{~h}$. 
The IR spectra of the products separated by GC / FT-IR are shown in Fig. 1.6. IR spectra of the product sampled at the retention times of 18.95-18.96, 19.04-19.06 and 19.23-19.27 min are also shown in Figs. 1.6(a)-(c). Fig. 1.6(a) shows that the product with retention time of $18.95-18.96 \mathrm{~min}$ had a characteristic absorption peak at 1282 $\mathrm{cm}^{-1}$ corresponding to a $\mathrm{C}-\mathrm{F}$ bond.
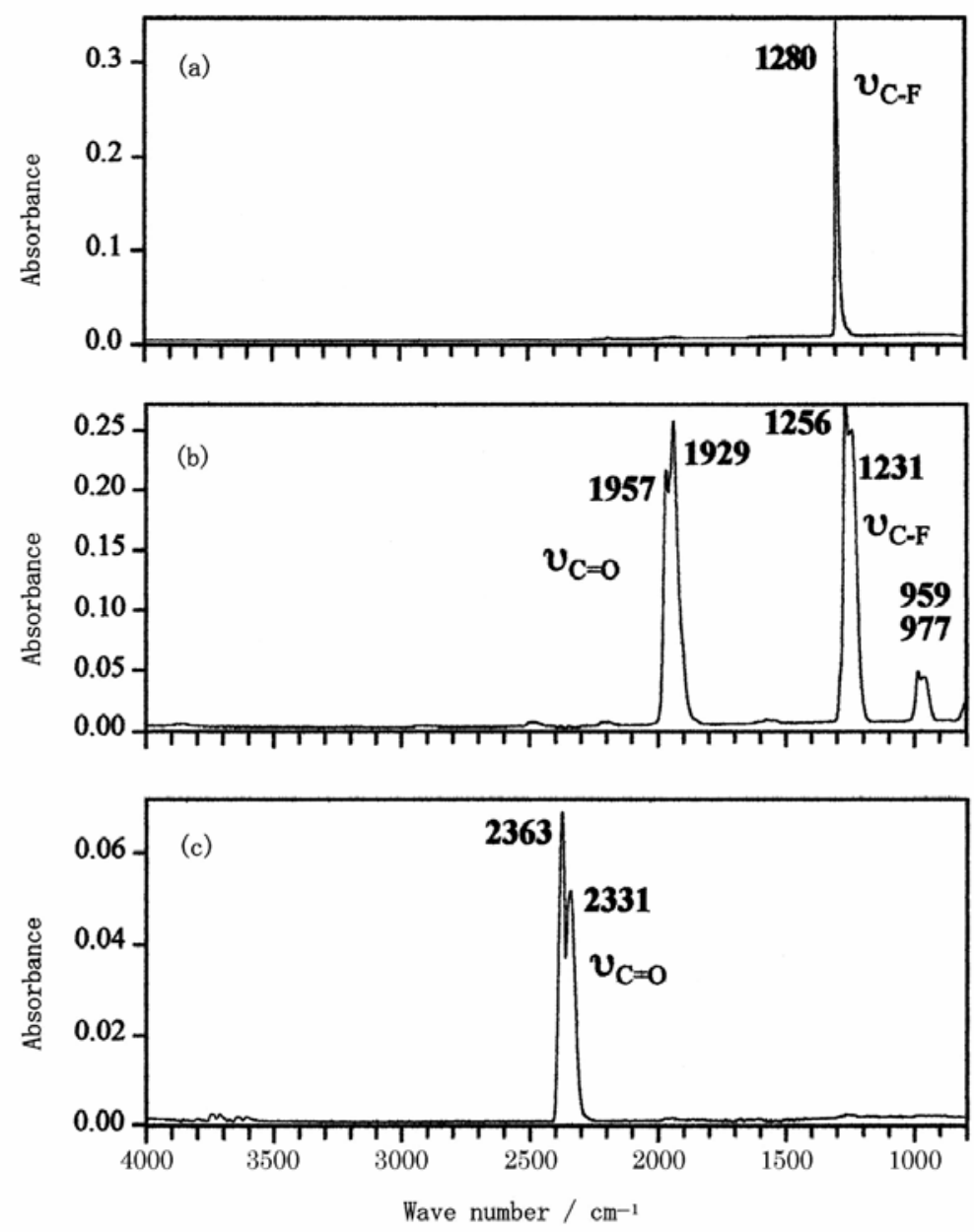

Fig. 1.6. GC / FT-IR spectra of the products at retention times of 18.95-18.96 $\min (\mathrm{a}), 19.04-19.06 \mathrm{~min}(\mathrm{~b})$ and $19.23-19.27 \min (\mathrm{c}) . \mathrm{CO}_{2}: \mathrm{F}_{2}$ $=50.7 \mathrm{kPa}: 101.3 \mathrm{kPa}$, reaction temp. $498 \mathrm{~K}$, and reaction time $50 \mathrm{~h}$. 
Similarly, the product with retention time of 19.04-19.06 $\mathrm{min}$ had characteristic absorption peaks at $1929 \mathrm{~cm}^{-1}(\mathrm{CF}=\mathrm{O}), 1256 \mathrm{~cm}^{-1}(\mathrm{C}-\mathrm{F})$ and $977 \mathrm{~cm}^{-1}(\mathrm{C}-\mathrm{F})$, as shown in Fig. 1.6(b), and the product with the retention time of 19.23-19.27 min had characteristic absorption peaks at $2331 \mathrm{~cm}^{-1}\left(\mathrm{CO}_{2}\right), 2361 \mathrm{~cm}^{-1}\left(\mathrm{CO}_{2}\right)$ and $3700 \mathrm{~cm}^{-1}$ $\left(\mathrm{CO}_{2}\right)$, as shown in Fig. 1.6(c). Matching with HR Nicolet Vapor Phase Library (Thermo Nicolet Japan Inc.) revealed that the respective products were $\mathrm{CF}_{4}$ [20], $\mathrm{COF}_{2}$ [21] and $\mathrm{CO}_{2}$.

Fig. 1.7 shows the total ion chromatogram of the gaseous reaction product and GC / MS spectra in the direct reaction. Three peaks existed at the retention times of 9.02 , 9.15 and $9.45 \mathrm{~min}$. The numbers in the figure indicate the $\mathrm{m} / z$ values. Fig. 1.7(b) shows the mass chromatogram of $\mathrm{m} / z=69,47,66$ and 44 . Ions with $\mathrm{m} / z=69,47,66$ and 44 corresponded, respectively, to $\mathrm{CF}_{3}{ }^{+}, \mathrm{COF}^{+}, \mathrm{COF}_{2}{ }^{+}$and $\mathrm{CO}_{2}{ }^{+}$[9]. Fig. 1.7(c) and (d) were mass spectra of the products sampled at 9.02 and $9.15 \mathrm{~min}$, where the peaks attributable to $\mathrm{N}_{2}$ and $\mathrm{O}_{2}$ were subtracted as a background. However, as shown in Fig. 1.7(c), one ion indicated $\mathrm{m} / \mathrm{z}=32$ because the oxygen in air mixed with the sample injection could not be subtracted sufficiently. The ion with $\mathrm{m} / z=69$, corresponding to $\mathrm{CF}_{3}{ }^{+}$was detected at the retention time of $9.02 \mathrm{~min}$; ions with $\mathrm{m} / \mathrm{z}=47$ and 66 corresponding to $\mathrm{COF}^{+}$and $\mathrm{COF}_{2}{ }^{+}$were detected at the retention time of $9.15 \mathrm{~min}$. Comparing the spectra to the data in NIST Library, the MS spectra at 9.02 and 9.15 min correctly corresponded, respectively, to $\mathrm{CF}_{4}$ [20], $\mathrm{COF}_{2}$ [21]. In addition, the result of positive CI-MS also suggested that $\mathrm{CF}_{4}[20]$ and $\mathrm{COF}_{2}[21]$ were produced.

It is noteworthy that the ions with $\mathrm{m} / \mathrm{z}=85$ and 54 corresponding, respectively, to $\mathrm{CF}_{3} \mathrm{O}^{+}$and $\mathrm{OF}_{2}{ }^{+}$were not observed by $\mathrm{GC} / \mathrm{MS}$ analysis. However, $\mathrm{CF}_{3} \mathrm{OF}$ was confirmed by FT-IR spectra, as shown in Fig. 1.4. The characteristic absorption peak corresponding to $\mathrm{OF}_{2}$ was also observed at $860 \mathrm{~cm}^{-1}$. Moreover, $\mathrm{CF}_{3} \mathrm{OF}$ and $\mathrm{OF}_{2}$ were 
not observed by GC / FT-IR and GC / MS [23] because these products had adsorbed on the column strongly and reacted with the column. Some fluorocompounds, such as $\mathrm{CH}_{3} \mathrm{SiF}_{3},\left(\mathrm{CH}_{3}\right)_{2} \mathrm{SiF}_{2}$ and fluorobenzene, were detected during measurements.
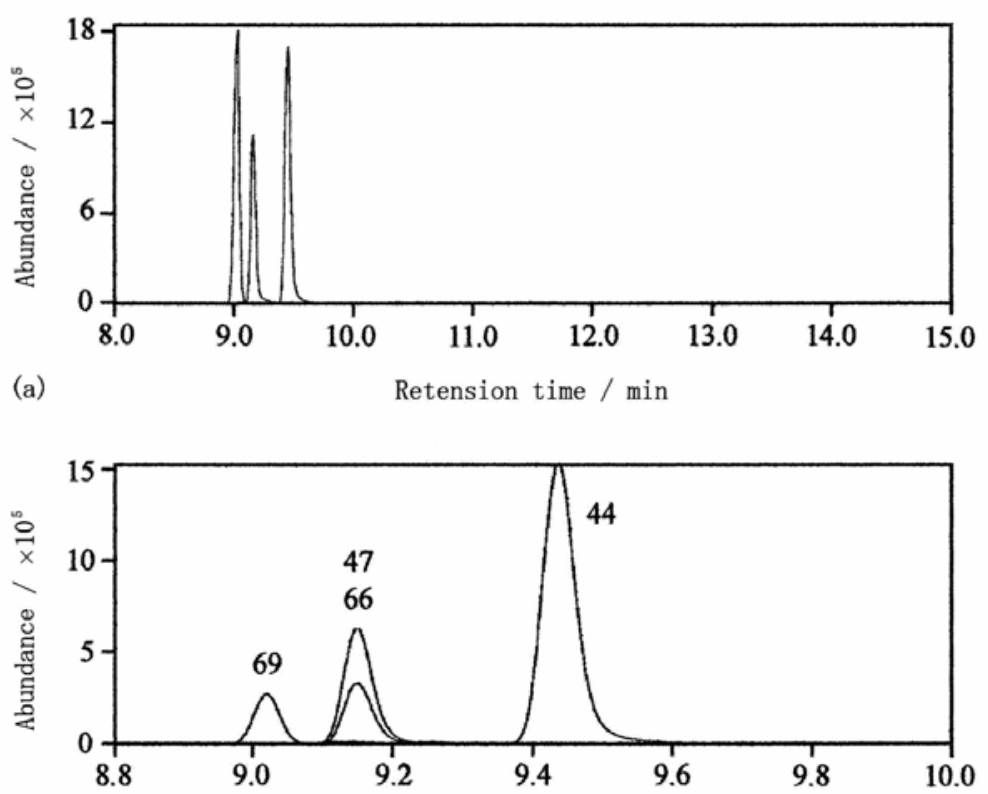

(b)

Retension time / min

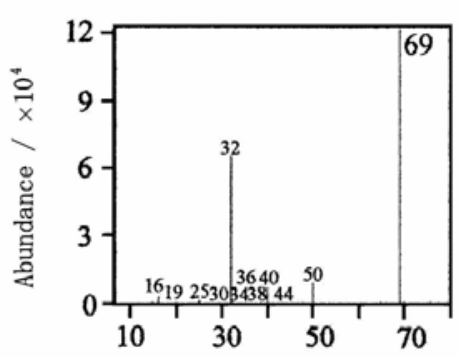

(c)

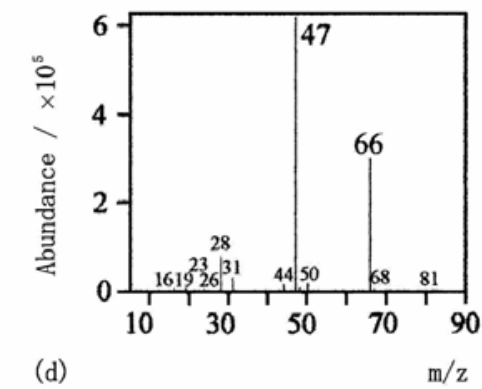

Fig. 1.7. GC / EI-MS spectra of the products. (a) Total ion chromatogram, (b) mass chromatogram at $m / z=69,66,47$ and 44 , (c) mass spectra at the retention time of $9.02 \mathrm{~min},(\mathrm{~d})$ at the retention time of $9.15 \mathrm{~min} . \mathrm{CO}_{2}: \mathrm{F}_{2}=$ $50.7 \mathrm{kPa}: 101.3 \mathrm{kPa}$, reaction temp. $498 \mathrm{~K}$, reaction time $40 \mathrm{~h}$, and $\mathrm{GC}$ oven temperature $223 \mathrm{~K}$. 
Results show that $\mathrm{CF}_{3} \mathrm{OF}, \mathrm{COF}_{2}$ and $\mathrm{CF}_{4}$ were the major products of the direct reaction between $\mathrm{CO}_{2}$ and $\mathrm{F}_{2}$ around $473 \mathrm{~K}$. It is noteworthy that the reaction between $\mathrm{CO}_{2}$ and $\mathrm{F}_{2}$ proceeded very slowly at room temperature. Confirmation of the $\mathrm{CF}_{3} \mathrm{OOCF}_{3}$ formation was not possible in the direct reaction. The generated $\mathrm{OF}_{2}$ at the reaction, along with $\mathrm{F}_{2}$, was eliminated by vaporization at $77 \mathrm{~K}$. Little $\mathrm{OF}_{2}$ remained in the product.

\subsubsection{In the presence of metal fluorides}

Reaction between $\mathrm{CO}_{2}$ and $\mathrm{F}_{2} \mathrm{n}$ the presence of metal fluoride was carried out under various conditions. In the presence of $\mathrm{NaF}$ and $\mathrm{EuF}_{3}$, the results of this reaction were similar to that of the direct reaction. However, the FT-IR spectrum of the reaction in the presence of CsF differed from that in the absence of metal fluoride and the presence of $\mathrm{EuF}_{3}$ and $\mathrm{NaF}$.

The FT-IR spectra of the reaction product in the presence of $3 \mathrm{~g}\left(2 \times 10^{-2} \mathrm{~mol}\right) \mathrm{CsF}$ are shown in Fig. 1.8. The shape of the absorption profile changed between 1100 and $1300 \mathrm{~cm}^{-1}$. Absorption peaks at 1167 and $1202 \mathrm{~cm}^{-1}$ newly appeared and the absorption peak at $1285 \mathrm{~cm}^{-1}$ shifted to $1289 \mathrm{~cm}^{-1}$. Fig. $1.8(\mathrm{~b})$ shows that the reaction product was clearly different at each reaction temperature. In the case reacted at $303 \mathrm{~K}$, the product displayed strong absorption peaks at 1267, 1248, 1202, $1186 \mathrm{~cm}^{-1}$, etc. The strong peak at $1202 \mathrm{~cm}^{-1}$ became weak at temperatures over $373 \mathrm{~K}$. The amount of the product having this strong peak decreased with increasing temperature. It disappeared completely at $473 \mathrm{~K}$. On the other hand, the strong peak of $1167 \mathrm{~cm}^{-1}$ appeared clearly at $498 \mathrm{~K}$. Strong absorption peaks at $1267,1248,1202,1186 \mathrm{~cm}^{-1}$, etc. were attributed to $\mathrm{CF}_{2}(\mathrm{OF})_{2}$ [14]. At high temperatures over $373 \mathrm{~K}$, the amount of $\mathrm{CF}_{3} \mathrm{OF}$ in the products 
increased at an increasing rate [24]. Moreover, the peak at $1167 \mathrm{~cm}^{-1}$ appeared at $498 \mathrm{~K}$ and was identified as that of $\mathrm{CF}_{3} \mathrm{OOCF}_{3}[15,16]$.

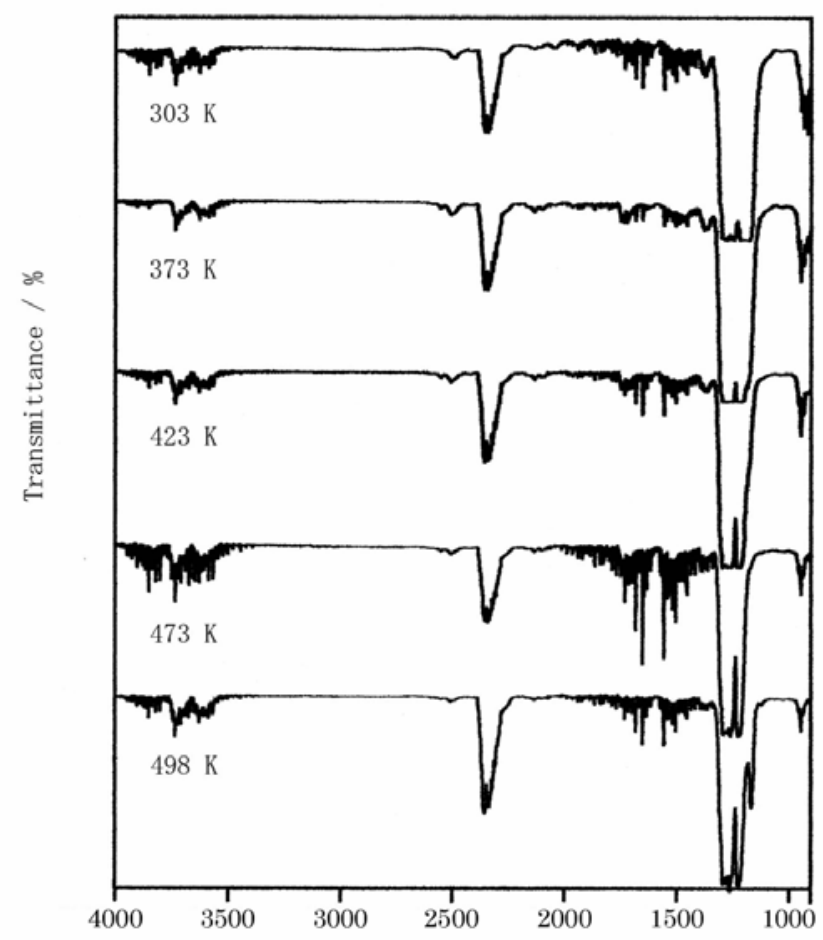

(a)

Wave number $/ \mathrm{cm}^{-1}$

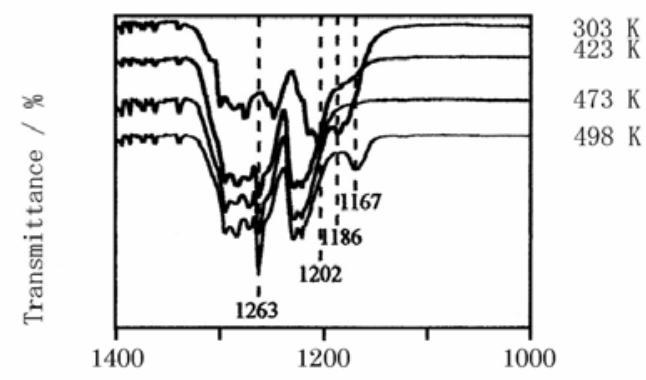

(b) Wave number $/ \mathrm{cm}^{-1}$

Fig. 1.8. FT-IR spectra of products in the presence of $\mathrm{CsF}$ at various temperatures. $\mathrm{CO}_{2}: \mathrm{F}_{2}=76 \mathrm{kPa}: 76 \mathrm{kPa}$, reaction time $50 \mathrm{~h}$. Sampling amount $2 \mathrm{kPa}(\mathrm{a})$ and $0.4 \mathrm{kPa}(\mathrm{b})$. 
In the presence of $260 \mathrm{mg}\left(1.65 \times 10^{-3}\right.$ mole $) \mathrm{CsF}$ at various temperatures, $\mathrm{CF}_{3} \mathrm{OF}$ and $\mathrm{OF}_{2}$ formed and $\mathrm{CF}_{2}(\mathrm{OF})_{2}$ did not form, even at $303 \mathrm{~K}$. The result was similar to that of the direct reaction when the amount of $\mathrm{CsF}$ was small.

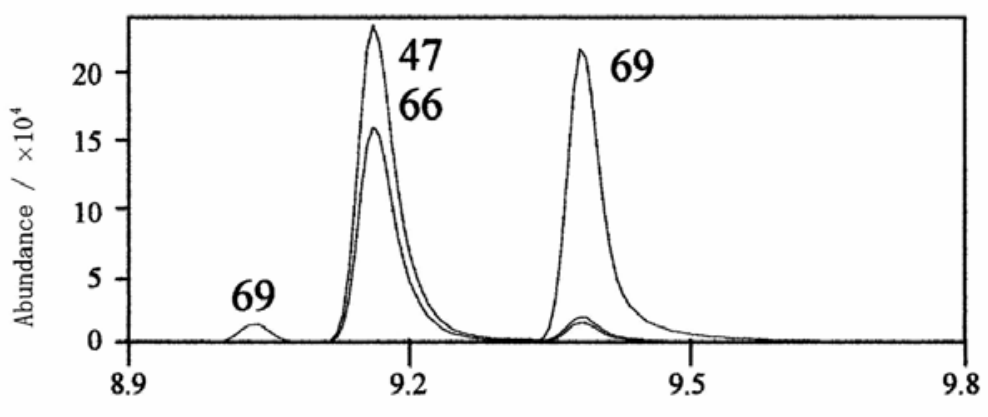

(a)

Retension time / min

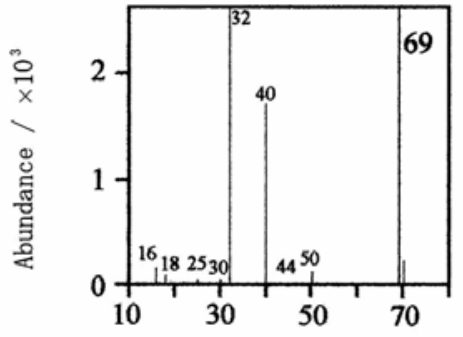

(b)

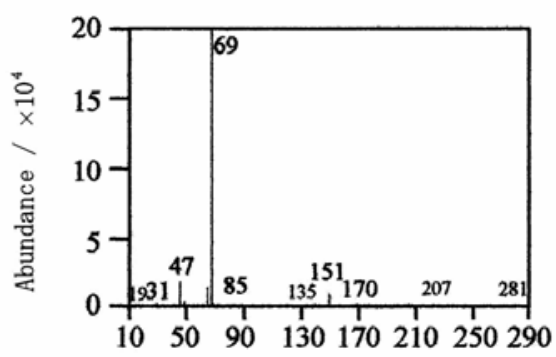

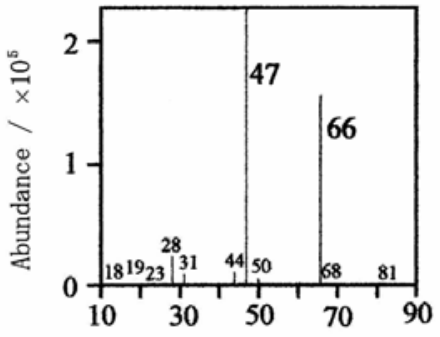

(c)

(d)

$\mathrm{m} / \mathrm{z}$

Fig. 1.9. Mass chromatogram and MS spectra of the products in the presence of CsF. (a) Mass chromatogram at $\mathrm{m} / \mathrm{z}=69,66$ and 47, (b) mass spectra at the retention time of $9.04 \mathrm{~min}$, (c) at the retention time of 9.17 $\min$ and (d) at the retention time of $9.39 \min . \mathrm{CO}_{2}: \mathrm{F}_{2}=76 \mathrm{kPa}: 76 \mathrm{kPa}$, reaction temp. $498 \mathrm{~K}$, reaction time $50 \mathrm{~h}$, and GC oven temperature $223 \mathrm{~K}$. 
Fig. 1.9 shows the mass chromatogram and MS spectra of the gaseous reaction product between $\mathrm{CO}_{2}$ and $\mathrm{F}_{2}$ in the presence of CsF. Fig. 1.9(a) shows that there were three peaks detected at the retention time of $9.04,9.17$, and $9.39 \mathrm{~min}$. Peaks with $\mathrm{m} / \mathrm{z}=$ 69 corresponding to $\mathrm{CF}_{3}{ }^{+}$appeared in the MS spectra (Fig. 1.9(b) and (d)) at the retention time of 9.04 and $9.39 \mathrm{~min}$. Ions with $\mathrm{m} / \mathrm{z}=47$ and 66 , corresponding, respectively, to $\mathrm{COF}^{+}$and $\mathrm{COF}_{2}{ }^{+}$, were observed at the retention time of $9.17 \mathrm{~min}$. Especially, as shown in Fig. 1.9(d), the product had peaks with $\mathrm{m} / z=151$ and 170 corresponding to $\mathrm{C}_{2} \mathrm{~F}_{5} \mathrm{O}_{2}{ }^{+}$and $\mathrm{C}_{2} \mathrm{~F}_{6} \mathrm{O}_{2}{ }^{+}$. Comparing the spectra to the data in the NIST Library, the products at $9.04,9.17$ and 9.39 min corresponded respectively to $\mathrm{CF}_{4}, \mathrm{COF}_{2}$ and $\mathrm{CF}_{3} \mathrm{OOCF}_{3}$.

Fig. 1.10 shows the reaction temperature dependence of the mass chromatogram of the reaction products in the presence of $\mathrm{CsF}$. Two peaks at 8.96 and 8.99 min were detected in the profile, corresponding, respectively, to $\mathrm{m} / z=47$ and 66 . The peak at 8.99 min disappeared at temperatures greater than $423 \mathrm{~K}$. The MS spectrum for the product at 8.96 min was determined as $\mathrm{COF}_{2}$. The two peaks in Fig. 1.10(a) proved that $\mathrm{COF}_{2}$ was produced in two different pathways.

The GC / MS oven temperature was reduced to $224 \mathrm{~K}$ from $242 \mathrm{~K}$ to separate the two peaks. Fig. 1.11(a) shows a mass chromatogram of $\mathrm{m} / z=47,66$ and 69 . The two peaks in Fig. 1.10(a) were separated and two peaks with the fragment ion of $\mathrm{m} / z=47$ and 66 were apparent at the respective retention times of 9.16 and 9.23 min; the MS spectra of the two peaks also agreed with $\mathrm{COF}_{2}$, as shown in Fig. 1.11(b) -2 and (b) -3 . The intensity ratio of the two peaks was about $1: 3$. This peak intensity at the retention time of 9.23 min tended to decrease during storage of the sample. The peak disappeared completely after 18 days storage. It is inferred that $\mathrm{CF}_{2}(\mathrm{OF})_{2}$ decomposed in the glass container to form $\mathrm{SiF}_{4}$. It seems that one of two pathways of $\mathrm{COF}_{2}$ formation must occur through the 
process of the decomposition of $\mathrm{CF}_{2}(\mathrm{OF})_{2}$ [14] in the $\mathrm{GC}$ column; the other pathway requires $\mathrm{COF}_{2}$ to be produced in the reaction between $\mathrm{CO}_{2}$ and $\mathrm{F}_{2}$.
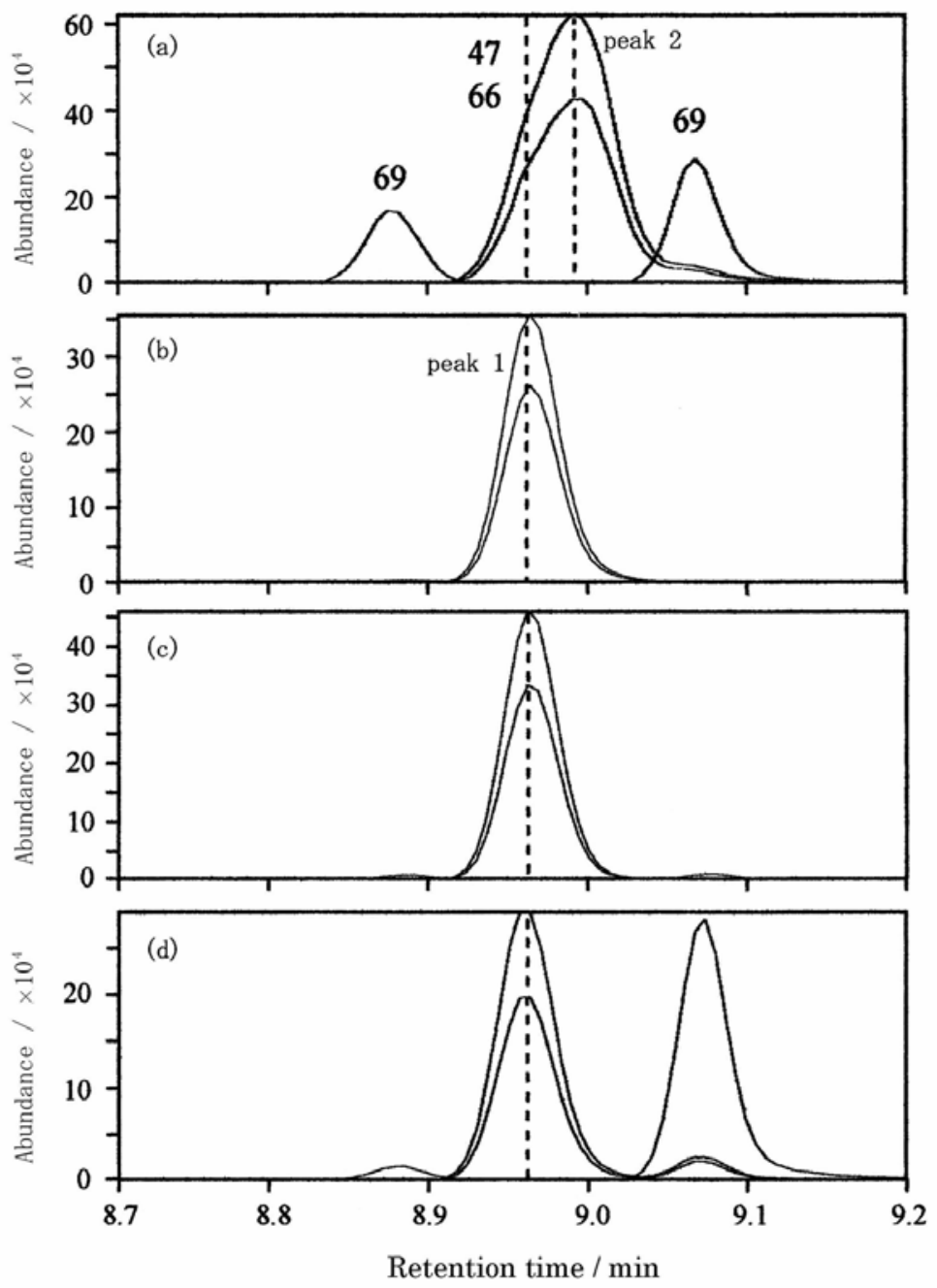

Fig. 1.10. Mass chromatograms of the products obtained in the presence of $\mathrm{CsF}$ at (a) $303 \mathrm{~K}$, (b) $423 \mathrm{~K}$, (c) $473 \mathrm{~K}$ and (d) $498 \mathrm{~K} . \mathrm{CO}_{2}: \mathrm{F}_{2}=76 \mathrm{kPa}: 76$ $\mathrm{kPa}$, reaction time $50 \mathrm{~h}$, and GC oven temperature $243 \mathrm{~K}$. 

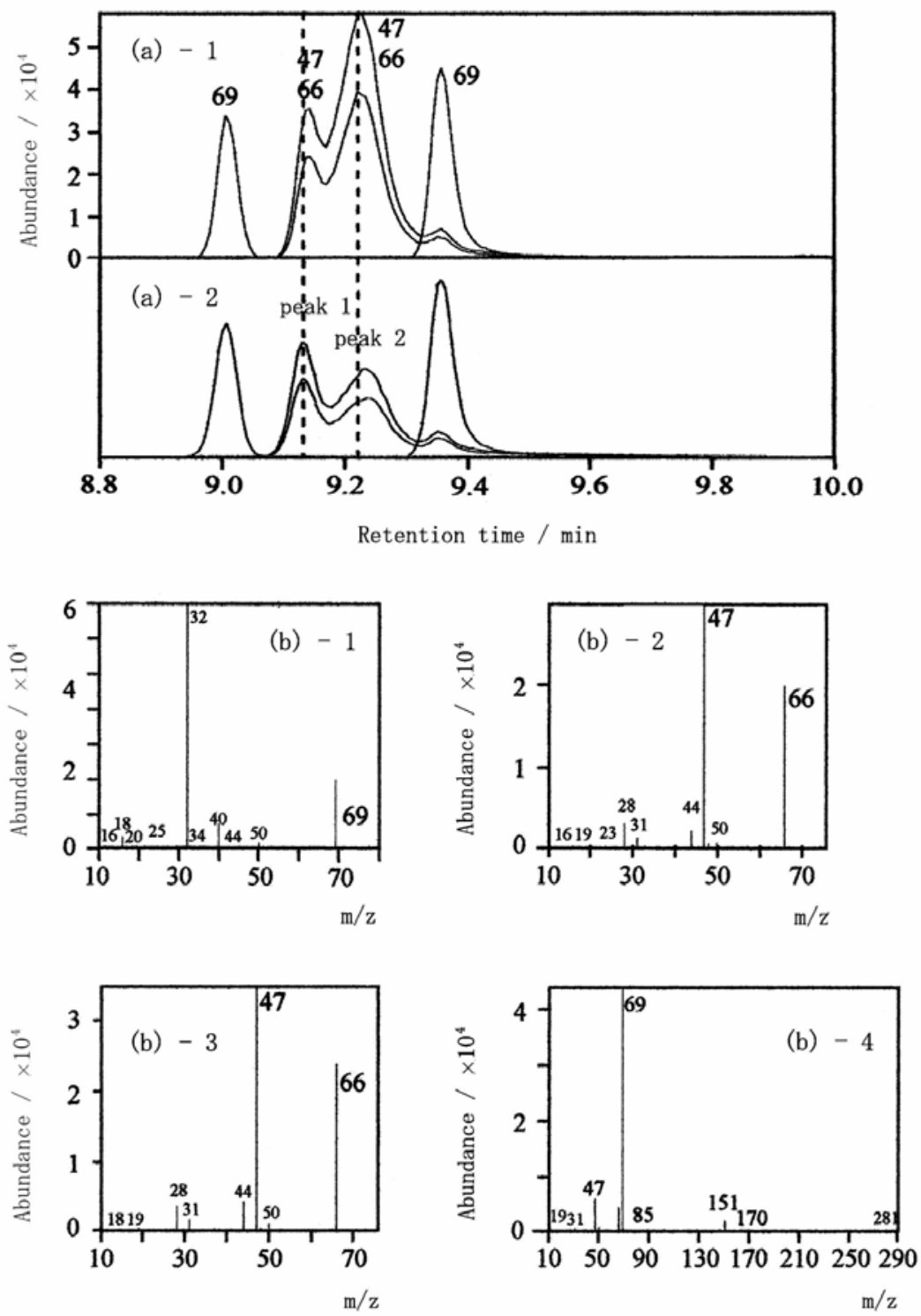

Fig. 1.11. Mass chromatogram of the products in the presence of $\mathrm{CsF}$ at the reaction temperature of $303 \mathrm{~K}$. (a) Mass chromatograms at $\mathrm{m} / \mathrm{z}=69,66$ and 47 after (a)-1 0 and (a)-2 4 days. (b) Mass spectra of the sample in (a)-1 having the retention time of (b)-1 $9.01 \mathrm{~min},(\mathrm{~b})-29.16 \mathrm{~min}$, (b)-3 9.23 min and (b) $-49.37 \min . \mathrm{CO}_{2}: \mathrm{F}_{2}=76 \mathrm{kPa}: 76 \mathrm{kPa}$, reaction time $50 \mathrm{~h}$, and GC oven temperature $223 \mathrm{~K}$. 
The product that had $\mathrm{m} / z=69$ at the retention time of ca. $9.37 \mathrm{~min}$ was also $\mathrm{CF}_{3} \mathrm{OOCF}_{3}$. The amount of $\mathrm{CF}_{3} \mathrm{OOCF}_{3}$ that was produced at $303 \mathrm{~K}$ was less than that at $498 \mathrm{~K}$. Apparently, the formation of $\mathrm{CF}_{3} \mathrm{OOCF}_{3}$ of more than $498 \mathrm{~K}$ occurred under the low fluorine content condition. It was unrelated with the decomposition of $\mathrm{CF}_{2}(\mathrm{OF})_{2}$ at $303 \mathrm{~K}$. Formation of $\mathrm{CF}_{4}$ did not proceed compared to the direct reaction.

The electronic states of metal fluorides before and after the reaction were analyzed using XPS. The color of $\mathrm{EuF}_{3}$ and $\mathrm{NaF}$ changed from white to light yellow, whereas XPS profiles of the $\mathrm{F}$ 1s electron of $\mathrm{EuF}_{3}$ and $\mathrm{NaF}$ did not change through the reaction. The color of $\mathrm{CsF}$ changed from white to pink in parts that contacted the nickel container. The color of $\mathrm{CsF}$ did not change in the parts that did not contact with the container. After a few days, the pink sample turned to yellow-green.

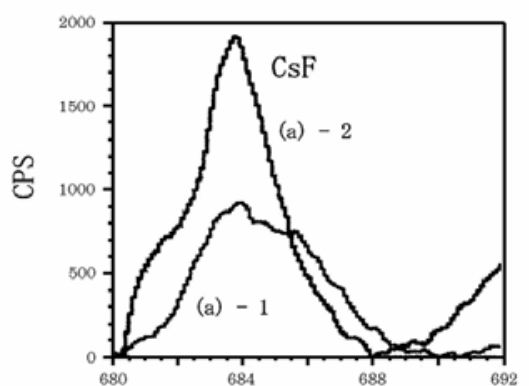

(a)

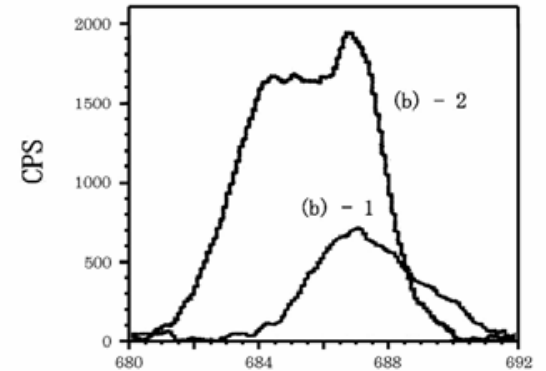

(b)

Fig. 1.12. XPS F1s spectrum of CsF before and after the reaction. (a) Before reaction: (a) -1 non-etching and (a) -2 after etching; (b) after reaction: (b) -1 non-etching and (b)-2 after etching. 
Fig. 1.12 shows XPS spectra [25] of the F 1s electron in CsF before (a) and after (b) used as the catalyst. The peak at $683.9 \mathrm{eV}$ appeared in the case of $\mathrm{CsF}$ before use. The peak at $685.6 \mathrm{eV}$ is visible in Fig. 1.12(a). This peak must correspond to the $\mathrm{F}$ 1s electron of the organic compound adsorbed in CsF. This peak disappeared at $685.6 \mathrm{eV}$ after 20 min of Ar ion etching, as shown in Fig. 1.12(a)-2. Therefore, it seems that the peak at 685.6 eV corresponded to some impurities on the surface of CsF. In Fig. 1.12(b), the peak at $687.1 \mathrm{eV}$ appeared, no peak was detected at $684 \mathrm{eV}$ before etching. The peak at 684.3 $\mathrm{eV}$ appeared after Ar ion etching, indicating that there must be two types of fluoride. The CsF surface was covered by some organic compound.

\subsubsection{Yields}

Quantitative analysis using the calibration line in Fig. 1.3 was carried out and the yield was calculated as a rate to $\mathrm{CO}_{2}$. The yield of the whole gaseous reaction product after eliminating $\mathrm{F}_{2}$ is shown in Table 1.3. In the direct reaction, yields of $\mathrm{COF}_{2}, \mathrm{CF}_{3} \mathrm{OF}$, $\mathrm{CF}_{4}$ and $\mathrm{CF}_{3} \mathrm{OOCF}_{3}$ increased with increasing reaction temperature and increasing reaction time, as shown in Fig. 1.13. The reaction rate under the condition of $\mathrm{CO}_{2} / \mathrm{F}_{2}=$ $76 \mathrm{kPa} / 76 \mathrm{kPa}$ was smaller than that of $\mathrm{CO}_{2} / \mathrm{F}_{2}=50.7 \mathrm{kPa} / 101.3 \mathrm{kPa}$. However, the yield of $\mathrm{COF}_{2}$ of the reaction at $\mathrm{CO}_{2} / \mathrm{F}_{2}=76 \mathrm{kPa} / 76 \mathrm{kPa}$ was larger than that at $\mathrm{CO}_{2} /$ $\mathrm{F}_{2}=50.7 \mathrm{kPa} / 101.3 \mathrm{kPa}$. 
Table 1.3

Yields of the products

\begin{tabular}{|c|c|c|c|c|c|c|}
\hline \multirow{2}{*}{$\begin{array}{l}\text { Temperature } \\
(\mathrm{K})\end{array}$} & \multirow{2}{*}{$\begin{array}{l}\text { Time } \\
\text { (h) }\end{array}$} & \multicolumn{5}{|c|}{ Yield(\%) } \\
\hline & & $\mathrm{COF}_{2}$ & $\mathrm{CF}_{3} \mathrm{OF}$ & $\mathrm{CF}_{4}$ & $\mathrm{CF}_{3} \mathrm{OOCF}_{3}$ & $\mathrm{CF}_{2}(\mathrm{OF})_{2}$ \\
\hline \multicolumn{7}{|c|}{ (a) Direct reaction } \\
\hline \multicolumn{7}{|c|}{$\mathrm{CO}_{2} / \mathrm{F}_{2}=76 \mathrm{kPa} / 76 \mathrm{kPa}$} \\
\hline 303 & 5 & 0 & 0.7 & 0 & 0 & 0 \\
\hline 373 & 5 & 0 & 0.7 & 0 & 0 & 0 \\
\hline 373 & 50 & 0 & 0.8 & 0 & 0 & 0 \\
\hline 423 & 5 & 0 & 1.4 & 0.1 & 0 & 0 \\
\hline 423 & 50 & 0.8 & 8.5 & 0.1 & 0 & 0 \\
\hline 473 & 5 & 0.5 & 10 & 0.1 & 0 & 0 \\
\hline 473 & 49 & 2.6 & 17 & 0.5 & 0 & 0 \\
\hline 498 & 2 & 0.2 & 3.5 & 0.2 & 0 & 0 \\
\hline 498 & 5 & 0.8 & 8 & 0.3 & 0 & 0 \\
\hline 498 & 10 & 0.4 & 6.6 & 0.1 & 0 & 0 \\
\hline 498 & 20 & 1.3 & 9.5 & 0.6 & 0 & 0 \\
\hline 498 & 30 & 1.3 & 13.8 & 0.3 & 0 & 0 \\
\hline 498 & 40 & 2.5 & 16.4 & 0.7 & 0 & 0 \\
\hline 498 & 50 & 2.2 & 20 & 1.1 & 0 & 0 \\
\hline 498 & 60 & 4.5 & 19.1 & 1.9 & 0 & 0 \\
\hline 498 & 72 & 11.1 & 32.1 & 4.6 & 0 & 0 \\
\hline 525 & 50 & 3.4 & 26.7 & 2.6 & 0 & 0 \\
\hline \multicolumn{7}{|c|}{$\mathrm{CO}_{2} / \mathrm{F}_{2}=50.7 \mathrm{kPa} / 101.3 \mathrm{kPa}$} \\
\hline 498 & 2 & & & & & \\
\hline 498 & 5 & & & & & \\
\hline 498 & 10 & & & & & \\
\hline 498 & 20 & 2.4 & 30.8 & 0.8 & 0 & 0 \\
\hline 498 & 30 & & & & & \\
\hline 498 & 40 & & & & & \\
\hline 498 & 50 & 6 & 51.5 & 1.5 & 0 & 0 \\
\hline 498 & 60 & 4.3 & 45.2 & 1.9 & 0 & 0 \\
\hline 498 & 72 & 5.3 & 43.4 & 1.8 & 0 & 0 \\
\hline \multicolumn{7}{|c|}{ (b) In the presence of $\mathrm{CsF}(3 \mathrm{~g})$} \\
\hline \multicolumn{7}{|c|}{$\mathrm{CO}_{2} / \mathrm{F}_{2}=76 \mathrm{kPa} / 76 \mathrm{kPa}$} \\
\hline 303 & 5 & 0.3 & 0 & 0 & 0.1 & 19.5 \\
\hline 303 & 50 & 0.5 & 0 & 0 & 0.1 & 36.4 \\
\hline 373 & 5 & & & & & \\
\hline 373 & 50 & 3.4 & 12.9 & 0 & 0 & 11.4 \\
\hline 423 & 5 & & & & & \\
\hline 423 & 50 & 4.4 & 22.3 & 0 & 0 & 5.6 \\
\hline 473 & 5 & & & & & \\
\hline 473 & 50 & 6.5 & 23.3 & 0.1 & 0.1 & 0 \\
\hline 498 & 2 & & & & & \\
\hline 498 & 5 & 3.7 & 11.1 & 0 & 0.4 & 0 \\
\hline 498 & 10 & & & & & \\
\hline 498 & 20 & 2.5 & 27.4 & 0 & 0.2 & 0 \\
\hline 498 & 30 & & & & & \\
\hline 498 & 40 & & & & & \\
\hline 498 & 50 & 2.9 & 17.2 & 0.2 & 2.5 & 0 \\
\hline 498 & 60 & & & & & \\
\hline 498 & 72 & & & & & \\
\hline
\end{tabular}




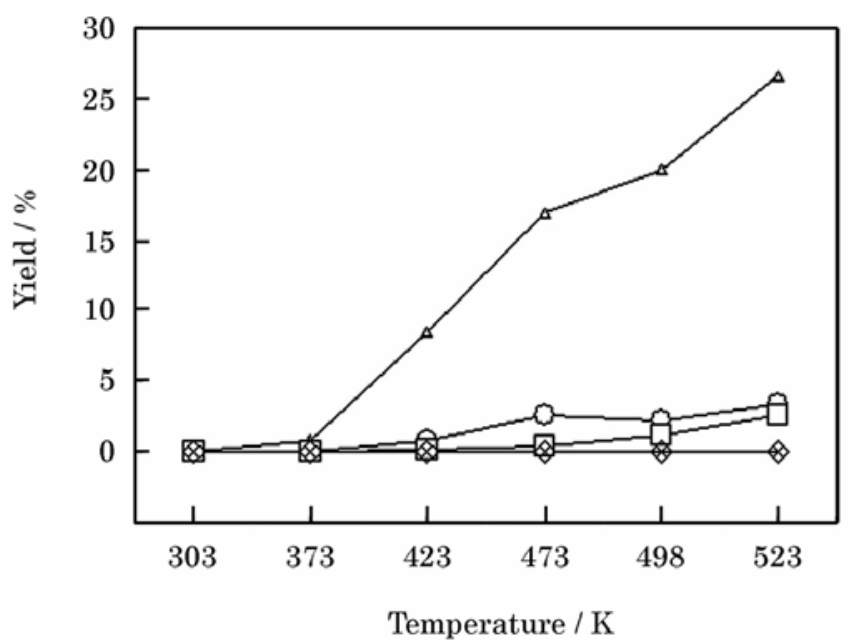

Fig. 1.13. Yields of products in the direct reactions at various temperatures. $\mathrm{CO}_{2}: \mathrm{F}_{2}=76 \mathrm{kPa}: 76 \mathrm{kPa}$ and reaction time $50 \mathrm{~h} .(\mathrm{O})$ $\mathrm{CF}_{2} \mathrm{O},(\triangle) \mathrm{CF}_{3} \mathrm{OF},(\square) \mathrm{CF}_{4},(\diamond) \mathrm{CF}_{3} \mathrm{OOCF}_{3}$ and $(\times) \mathrm{CF}_{2}(\mathrm{OF})_{2}$

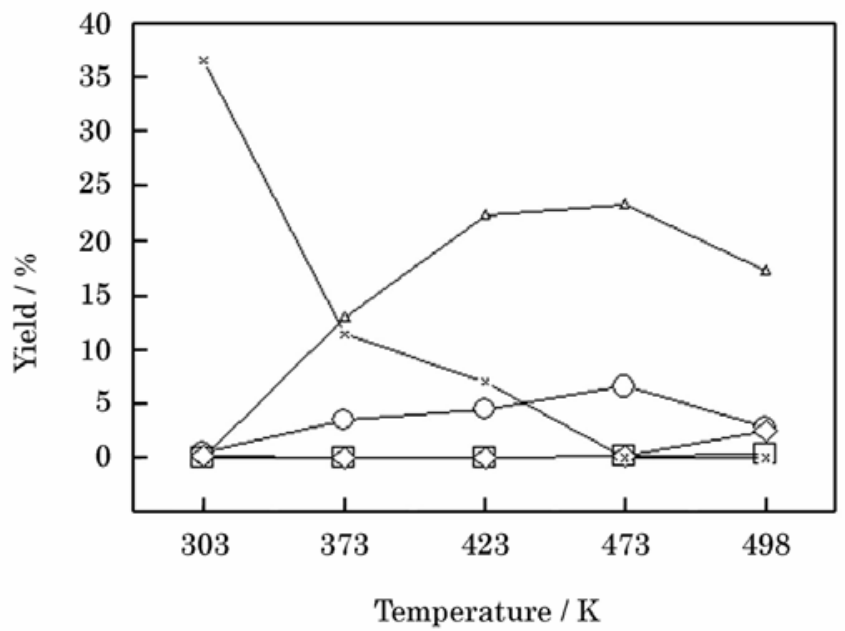

Fig. 1.14. Yields of products in the presence of $\mathrm{CsF}$ at various temperatures. $\mathrm{CO}_{2}: \mathrm{F}_{2}=76 \mathrm{kPa}: 76 \mathrm{kPa}$ and reaction time $50 \mathrm{~h} .(\bigcirc) \mathrm{CF}_{2} \mathrm{O}$, $(\triangle) \mathrm{CF}_{3} \mathrm{OF},(\square) \mathrm{CF}_{4},(\diamond) \mathrm{CF}_{3} \mathrm{OOCF}_{3}$ and $(\times) \mathrm{CF}_{2}(\mathrm{OF})_{2}$. 
In the presence of $\mathrm{CsF}(3 \mathrm{~g})$, the yields of $\mathrm{COF}_{2}, \mathrm{CF}_{3} \mathrm{OF}, \mathrm{CF}_{4}, \mathrm{CF}_{3} \mathrm{OOCF}_{3}$ and $\mathrm{CF}_{2}(\mathrm{OF})_{2}$ were measured under the conditions of $\mathrm{CO}_{2} / \mathrm{F}_{2}=76 \mathrm{kPa} / 76 \mathrm{kPa}$, with $50 \mathrm{~h}$ reaction time. The yields, which are shown in Fig. 1.14, did not increase monotonously with increasing reaction temperature. The yield of $\mathrm{CF}_{2}(\mathrm{OF})_{2}$ decreased with increasing temperature. The yields of $\mathrm{COF}_{2}$ and $\mathrm{CF}_{3} \mathrm{OF}$ had the highest values. In addition, $\mathrm{CF}_{3} \mathrm{OOCF}_{3}$ was detectable at temperatures higher than $498 \mathrm{~K}$. The yields of $\mathrm{COF}_{2}$ and $\mathrm{CF}_{3} \mathrm{OF}$ become larger in the presence of $\mathrm{CsF}$ than in the direct reaction at temperatures of $373-473 \mathrm{~K}$. Furthermore, the yields of $\mathrm{CF}_{3} \mathrm{OOCF}_{3}$ appeared at the high-temperature range over $473 \mathrm{~K}$. However, $\mathrm{CF}_{4}$ was only slightly observed in the presence of $\mathrm{CsF}$, as shown in Fig. 1.14. Total yields of the reaction products were equal, about $23 \%$, for both reactions at $498 \mathrm{~K}$.

On the other hand, in the presence of $0.25 \mathrm{~g}\left(1.65 \times 10^{-3} \mathrm{~mol}\right) \mathrm{CsF}$, the reaction product was similar to the direct reaction. The different yields of $\mathrm{COF}_{2}$ and $\mathrm{CF}_{3} \mathrm{OF}$ can be explained using the reaction mechanism.

In the presence of $0.35 \mathrm{~g}\left(1.65 \times 10^{-3} \mathrm{~mol}\right) \mathrm{EuF}_{3}$ under the condition of $\mathrm{CO}_{2} / \mathrm{F}_{2}=76$ $\mathrm{kPa} / 76 \mathrm{kPa}$ at the reaction time of $50 \mathrm{~h}$, the yields of $\mathrm{COF}_{2}, \mathrm{CF}_{3} \mathrm{OF}, \mathrm{CF}_{4}$ and $\mathrm{CF}_{3} \mathrm{OOCF}_{3}$ are shown in Fig. 1.15. Those yields were identical to those of the direct reaction. It appears that the amount of $\mathrm{EuF}_{3}$ was insufficient to hasten the reaction.

Fig. 1.16 shows the yield of the direct reaction under the condition of $\mathrm{CO}_{2} / \mathrm{F}_{2}=76$ $\mathrm{kPa} / 76 \mathrm{kPa}$ at $498 \mathrm{~K}$. In this case, it seemed that the yields of $\mathrm{COF}_{2}, \mathrm{CF}_{3} \mathrm{OF}$ and $\mathrm{CF}_{4}$ at the direct reaction increased with increasing reaction time, as shown in Table 1.3. 


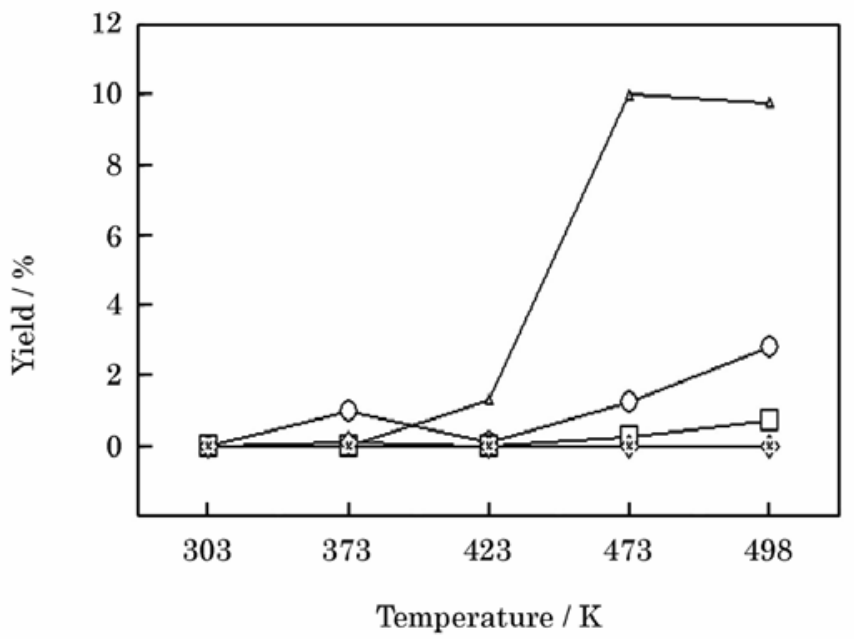

Fig. 1.15. Yields of products in the presence of $\mathrm{EuF}_{3}$ at various temperatures. $\mathrm{CO}_{2}: \mathrm{F}_{2}=76 \mathrm{kPa}: 76 \mathrm{kPa}$ and reaction time $50 \mathrm{~h} .(\bigcirc) \mathrm{CF}_{2} \mathrm{O}$, $(\triangle) \mathrm{CF}_{3} \mathrm{OF},(\square) \mathrm{CF}_{4},(\diamond) \mathrm{CF}_{3} \mathrm{OOCF}_{3}$ and $(\times) \mathrm{CF}_{2}(\mathrm{OF})_{2}$

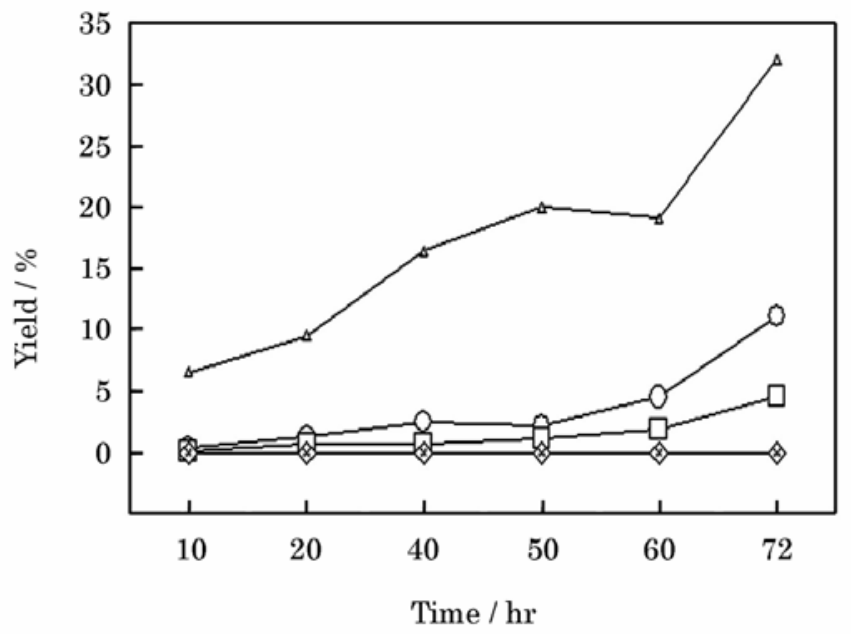

Fig. 1.16. Yields of products in the direct reaction at $498 \mathrm{~K}$ with various reaction times. $\mathrm{CO}_{2}: \mathrm{F}_{2}=76 \mathrm{kPa}: 76 \mathrm{kPa} .(\bigcirc) \mathrm{CF}_{2} \mathrm{O},(\triangle) \mathrm{CF}_{3} \mathrm{OF},(\square) \mathrm{CF}_{4}$, $(\diamond) \mathrm{CF}_{3} \mathrm{OOCF}_{3}$ and $(x) \mathrm{CF}_{2}(\mathrm{OF})_{2}$. 
In summary, the best yield of $\mathrm{COF}_{2}$ was $11.1 \%$ under the reaction condition of $\mathrm{CO}_{2} /$ $\mathrm{F}_{2}=76 \mathrm{kPa} / 76 \mathrm{kPa}$, with reaction temperature of $498 \mathrm{~K}$ and reaction time of $72 \mathrm{~h} . \mathrm{In}$ the presence of $\mathrm{CsF}$, the best yield of $\mathrm{COF}_{2}$ was $6.5 \%$ under the reaction conditions of $\mathrm{CO}_{2} / \mathrm{F}_{2}=76 \mathrm{kPa} / 76 \mathrm{kPa}$, with reaction temperature of $473 \mathrm{~K}$ and reaction time of $50 \mathrm{~h}$.

\subsubsection{Reaction rate}

The reaction of $\mathrm{COF}_{2}$ generation can be written as $\mathrm{CO}_{2}+\mathrm{F}_{2}=\mathrm{COF}_{2}$. For the reaction rate, $\nu$ is $k\left[\mathrm{CO}_{2}\right]\left[\mathrm{F}_{2}\right]$, where $k$ is a rate constant.

The whole amount of $\mathrm{COF}_{2}$ produced during the reaction process was calculated as the amount of the products that were produced through $\mathrm{COF}_{2}$ pathways such as $\mathrm{COF}_{2}$, $\mathrm{CF}_{3} \mathrm{OF}, \mathrm{CF}_{4}$ and $\mathrm{CF}_{3} \mathrm{OOCF}_{3}$ in the direct reaction. However, under the existence of $\mathrm{CsF}$ (3 g) it was calculated as the total of $\mathrm{COF}_{2}, \mathrm{CF}_{4}$ and $\mathrm{CF}_{3} \mathrm{OOCF}_{3}$.

Table 1.4

Formation rate of $\mathrm{COF}_{2}$ and rate constant and activation energy of $\mathrm{COF}_{2}$ formation

\begin{tabular}{|c|c|c|c|c|c|c|}
\hline \multirow[t]{2}{*}{ Catalyst } & \multicolumn{2}{|c|}{ Pressure $(\mathrm{kPa}$} & \multirow{2}{*}{$\begin{array}{l}\text { Temperature, } \\
\mathrm{T}(\mathrm{K})\end{array}$} & \multirow{2}{*}{$\begin{array}{l}\text { Formation rate, } \\
\mathrm{v}\left(\mathrm{mol} \mathrm{dm} \mathrm{m}^{-3} \mathrm{~h}^{-1}\right)\end{array}$} & \multirow{2}{*}{$\begin{array}{l}\text { Rate constant, } \\
\mathrm{k}\left(\mathrm{dm}^{-3} \mathrm{~mol}^{-1} \mathrm{~h}^{-1}\right)\end{array}$} & \multirow[t]{2}{*}{ Activation energy } \\
\hline & $\mathrm{CO}_{2}$ & $\mathrm{~F}_{2}$ & & & & \\
\hline \multirow[t]{5}{*}{ none } & 50.7 & 101.3 & 498 & $2 \times 10^{-4}$ & 1.63 & \multirow{5}{*}{45.7} \\
\hline & 76 & 76 & 373 & $0.4 \times 10^{-5}$ & 0.00594 & \\
\hline & 76 & 76 & 423 & $0.5 \times 10^{-4}$ & 0.0859 & \\
\hline & 76 & 76 & 473 & $1 \times 10^{-4}$ & 0.208 & \\
\hline & 76 & 76 & 498 & $1 \times 10^{-4}$ & 0.232 & \\
\hline \multirow[t]{3}{*}{$\mathrm{CsF}(3 \mathrm{~g})$} & 76 & 76 & 303 & $6 \times 10^{-6}$ & 0.00966 & \multirow[t]{3}{*}{24.2} \\
\hline & 76 & 76 & 373 & $2 \times 10^{-5}$ & 0.0402 & \\
\hline & 76 & 76 & 498 & $5 \times 10^{-4}$ & 1.88 & \\
\hline \multirow[t]{4}{*}{$\mathrm{EuF}_{3}(0.35 \mathrm{~g})$} & 76 & 76 & 373 & $0.5 \times 10^{-5}$ & 0.00629 & \multirow[t]{4}{*}{38.9} \\
\hline & 76 & 76 & 423 & $0.8 \times 10^{-5}$ & 0.00932 & \\
\hline & 76 & 76 & 473 & $0.6 \times 10^{-4}$ & 0.0789 & \\
\hline & 76 & 76 & 498 & $0.8 \times 10^{-4}$ & 0.121 & \\
\hline
\end{tabular}


The $\mathrm{COF}_{2}$ formation rates and rate constants are shown in Table 1.4. The $\mathrm{COF}_{2}$ formation rates in the presence of $\mathrm{CsF}$ were five times larger than those without any catalyst.

\subsubsection{Activation energy of $\mathrm{COF}_{2}$ formation}

The activation energy of $\mathrm{COF}_{2}$ is estimated according to the following reaction. The relation between the rate constant $k$ and the temperature $T$ is usually expressed as an Arrhenius reaction:

$k=A \mathrm{e}-E / R T$

The value of the activation energy $\mathrm{E}$ was determined from the gradient of the plots of $\ln k v \mathrm{~S}-1 / T$.

The values of the activation energy are shown in Table 1.4. The activation energy in case of using $\mathrm{CsF}$ was the smallest among all that were obtained.

\subsubsection{Reaction mechanism}

Any halogen, $\mathrm{X}_{2}$, may react by either of two mechanisms as the following.

( i ) atomic, often light- and heat-catalyzed, leads to the active $\mathrm{X}^{*}$.

(ii) ionic, leads to the active $\mathrm{X}^{-}$.

However, fluorine $[7,8]$ is the most electronegative of all elements, and has a high positive nuclear charge, it should react atomically rather than ionically. Because the complete removal of electron from it, to form a positive $\mathrm{F}^{+}$ion, would be very difficult.

The gas phase fluorinations by direct reaction with fluorine as well as in the metal 
fluoride are known for a wide variety of reactions.

The following reaction mechanisms are reasonable to explain the observed products.

The radical reaction probably takes place, especially in the gas phase between $\mathrm{CO}_{2}$ and $\mathrm{F}_{2}$. The reaction mechanism will be considered as the following:

$$
\begin{aligned}
& \triangle \\
& \mathrm{F}_{2} \rightarrow \mathrm{F}^{\cdot} \\
& \mathrm{CO}_{2}+\mathrm{F}^{\cdot} \rightarrow \mathrm{CF}(\mathrm{O}) \mathrm{O}^{\cdot} \\
& \mathrm{CF}(\mathrm{O}) \mathrm{O}^{\bullet}+\mathrm{F}_{2} \rightarrow \mathrm{COF}_{2}+\mathrm{OF}^{\cdot} \\
& \mathrm{OF}^{\cdot}+\mathrm{F}_{2} \rightarrow \mathrm{OF}_{2}+\mathrm{F}^{\cdot} \\
& \mathrm{COF}_{2}+\mathrm{F}^{\cdot} \rightarrow \mathrm{CF}_{3} \mathrm{O}^{\cdot} \\
& \mathrm{CF}_{3} \mathrm{O}^{\bullet}+\mathrm{F}_{2} \rightarrow \mathrm{CF}_{3} \mathrm{OF}+\mathrm{F}^{\cdot} \\
& \mathrm{CF}_{3} \mathrm{OF}+\mathrm{F}^{\cdot} \rightarrow \mathrm{CF}_{3}^{\cdot}+\mathrm{OF}_{2} \\
& \mathrm{CF}_{3} \cdot+\mathrm{F}_{2} \rightarrow \mathrm{CF}_{4}+\mathrm{F}^{\cdot} \\
& \mathrm{CF}_{3} \mathrm{O}^{\bullet}+\mathrm{CF}_{3} \mathrm{O}^{\cdot} \rightarrow \mathrm{CF}_{3} \mathrm{OOCF}_{3} \\
& \mathrm{CF}_{3} \mathrm{O}^{\cdot}+\mathrm{CF}_{3} \mathrm{O}^{\cdot} \rightarrow \mathrm{CF}_{3} \mathrm{OF}+\mathrm{COF}_{2} \\
& \mathrm{OF}^{\cdot}+\mathrm{OF}^{\cdot} \rightarrow \mathrm{F}_{2}+\mathrm{O}_{2}
\end{aligned}
$$

The fluorine radical $\left(\mathrm{F}^{*}\right)$ is produced by the dissociation of $\mathrm{F}_{2}$ in reaction (1); subsequently, $\mathrm{F}^{\cdot}$ might go on to react with $\mathrm{CO}_{2}$. In this case, the $\mathrm{F}^{\cdot}$ formation is hastened by heating in the initiation step (reaction (1)). The reaction (1) proceeds very slowly at room temperature; it proceeds remarkably faster at $473 \mathrm{~K}$.

Some subsequent steps are shown in reactions (2)-(8), and $\mathrm{COF}_{2}, \mathrm{CF}_{3} \mathrm{OF}$ and $\mathrm{CF}_{4}$ are produced. These products were detected as described above. Many other subsequent steps are possible; they might proceed in parallel.

Similarly, the termination steps are shown in reactions (9)-(11), and $\mathrm{CF}_{3} \mathrm{OF}$ and 
$\mathrm{CF}_{3} \mathrm{OOCF}_{3}$ are produced. Thus, this direct reaction process, including the reactions (1)-(11), involves a free radical chain reaction [26]. In our present experiment, it seemed that reaction (9) proceeded only slightly.

On the other hand, another reaction between $\mathrm{CO}_{2}$ and $\mathrm{F}_{2}$ can occur. Hohorst and Shreeve report that when the reaction temperature is near room temperature and the $\mathrm{F}_{2}$ amount is sufficient under the existence of $\mathrm{CsF}$, the reaction product between $\mathrm{CO}_{2}$ and $\mathrm{F}_{2}$ is $\mathrm{CF}_{2}(\mathrm{OF})_{2}$ [24]. However, $\mathrm{CF}_{3} \mathrm{OF}$ and $\mathrm{OF}_{2}$ are formed when the reaction temperature rises and the $\mathrm{F}_{2}$ amount is insufficient. Identical results were confirmed through our experiments.

In the first step, the adsorption of $\mathrm{F}_{2}$ on the $\mathrm{CsF}$ surface must take place. The first ionization energy of $\mathrm{Cs}$ is $3.89 \mathrm{eV}$. In addition, fluorine has the largest electronegativity. Therefore, $\mathrm{CsF}$ is the material that has the highest ionic bond. This highly ionic bond apparently causes the larger polarization of $\mathrm{F}_{2}$ molecule adsorbed on $\mathrm{CsF}$. This polarization of the $\mathrm{F}_{2}$ molecule might promote the reaction between $\mathrm{CO}_{2}$ and $\mathrm{F}_{2}$.

It has also been reported that atomic fluorine [27] must be generated easily at the $\mathrm{CsF}$ interface. The atomic fluorine might proceed to react with $\mathrm{CO}_{2}$ as well as fluorine radical.

$$
\begin{gathered}
\mathrm{CsF} \\
\mathrm{F}_{2} \rightarrow 2 \mathrm{~F}
\end{gathered}
$$

In many reactions, the reaction intermediates should be postulated. The XPS analyses of the $\mathrm{CsF}$ surface give some information about the organic compounds as intermediates.

In the second step, it seems to form $\mathrm{CF}_{2}(\mathrm{OF})_{2}$ by passing through reactions (12)_(14). The possible reaction intermediates of $\left[\mathrm{CF}(\mathrm{O}) \mathrm{O}^{\delta-} \mathrm{Cs}^{\delta+} \mathrm{F}\right]$ and $\left[\mathrm{CF}_{2}(\mathrm{OF}) \mathrm{O}^{\delta-} \mathrm{Cs}^{\delta+} \mathrm{F}\right]$ 
[28-30] shown in the following reactions must be formed:

$$
\begin{aligned}
& \mathrm{CO}_{2}+\mathrm{F}_{2}+\mathrm{CsF} \rightarrow\left[\mathrm{CF}(\mathrm{O}) \mathrm{O}^{\delta-} \mathrm{Cs}^{\delta+} \mathrm{F}\right], \mathrm{CsF}(\mathrm{CF}(\mathrm{O}) \mathrm{OF}) \\
& {\left[\mathrm{CF}(\mathrm{O}) \mathrm{O}^{\delta-} \mathrm{Cs}^{\delta+} \mathrm{F}\right]+\mathrm{F}_{2} \rightarrow\left[\mathrm{CF}_{2}(\mathrm{OF}) \mathrm{O}^{\delta-} \mathrm{Cs}^{\delta+} \mathrm{F}\right]} \\
& {\left[\mathrm{CF}_{2}(\mathrm{OF}) \mathrm{O}^{\delta-} \mathrm{Cs}^{\delta+} \mathrm{F}\right]+\mathrm{F}_{2} \rightarrow \mathrm{CF}_{2}(\mathrm{OF})_{2}+\mathrm{CsF}}
\end{aligned}
$$

At temperatures higher than $303 \mathrm{~K}$ or under low fluorine gas pressure, $\mathrm{CF}_{3} \mathrm{OF}$ seems to form, leaving $\mathrm{OF}_{2}$ by reaction (15) instead of proceeding to reaction (14):

$$
\begin{aligned}
& {\left[\mathrm{CF}_{2}(\mathrm{OF}) \mathrm{O}^{\delta-} \mathrm{Cs}^{\delta+} \mathrm{F}\right]+\mathrm{CsF} \rightarrow \mathrm{CF}_{3} \mathrm{OF}+\mathrm{OF}_{2}+\mathrm{Cs}_{2} \mathrm{O}} \\
& \mathrm{Cs}_{2} \mathrm{O}+\mathrm{F}_{2} \rightarrow \mathrm{CsF}+\mathrm{OF}_{2}
\end{aligned}
$$

The concentration of $\mathrm{F}_{2}$ adsorbed on the surface must decrease with increasing temperature. Therefore, it seems to be difficult for the intermediate compound to react with the $\mathrm{F}_{2}$ molecule. The possible reaction intermediate $\left[\mathrm{CF}_{2}(\mathrm{OF}) \mathrm{O}^{\delta-} \mathrm{Cs}^{\delta+} \mathrm{F}\right]$ reacts with $\mathrm{CsF}$, and $\mathrm{CF}_{3} \mathrm{OF}$ must be formed by reactions (15) and (21). In fact, $\mathrm{Cs}_{2} \mathrm{O}$ reacts immediately with $\mathrm{F}_{2}$, as in reaction (16), and it will return to $\mathrm{CsF}$. The low $\mathrm{F}_{2}$ concentration on the $\mathrm{CsF}$ surface induced by the low $\mathrm{F}_{2}$ pressure yields the similar result to that shown above.

Fig. 1.14 shows the temperature dependence of the yield of $\mathrm{COF}_{2}$. It seems that pathways (17)-(21) are considered to form $\mathrm{COF}_{2}$ and $\mathrm{CF}_{3} \mathrm{OF}$ [31-33]. With rising temperature, $\mathrm{OF}_{2}$ would be similarly produced as follows; $\mathrm{OF}_{2}$ would remain in the products at higher temperature like in case of $\mathrm{CF}_{3} \mathrm{OF}$ :

$$
\begin{aligned}
& {\left[\mathrm{CF}(\mathrm{O}) \mathrm{O}^{\delta-} \mathrm{Cs}^{\delta+} \mathrm{F}\right]+\mathrm{F}_{2} \rightarrow \mathrm{COF}_{2}+\mathrm{OF}_{2}+\mathrm{CsF}} \\
& {\left[\mathrm{CF}(\mathrm{O}) \mathrm{O}^{\delta}{ }^{-} \mathrm{Cs}^{\delta+} \mathrm{F}\right]+\mathrm{CsF} \rightarrow \mathrm{COF}_{2}+\mathrm{Cs}_{2} \mathrm{O}} \\
& {\left[\mathrm{CF}_{2}(\mathrm{OF}) \mathrm{O}^{\delta-} \mathrm{Cs}^{\delta+} \mathrm{F}\right]+\mathrm{F}_{2} \rightarrow \mathrm{COF}_{2}+\mathrm{OF}_{2}+\mathrm{CsF}}
\end{aligned}
$$




$$
\begin{aligned}
& \mathrm{CF}_{2} \mathrm{O}+\mathrm{CsF} \rightarrow\left[\mathrm{CF}_{3} \mathrm{O}^{\delta-} \mathrm{Cs}^{\delta+} \mathrm{F}\right] \\
& {\left[\mathrm{CF}_{3} \mathrm{O}^{\delta-} \mathrm{Cs}^{\delta+} \mathrm{F}\right]+\mathrm{F}_{2} \rightarrow \mathrm{CF}_{3} \mathrm{OF}+\mathrm{CsF}}
\end{aligned}
$$

Fig. 1.14 shows that the yield of $\mathrm{CF}_{3} \mathrm{OF}$ increased with rising reaction temperature in the temperature range of $373-473 \mathrm{~K}$. The formation and stability of the possible intermediates such as $\left[\mathrm{CF}(\mathrm{O}) \mathrm{O}^{\delta-} \mathrm{Cs}^{\delta+} \mathrm{F}\right],\left[\mathrm{CF}_{2}(\mathrm{OF}) \mathrm{O}^{\delta-} \mathrm{Cs}^{\delta+} \mathrm{F}\right]$ and $\left[\mathrm{CF}_{3} \mathrm{O}^{\delta-} \mathrm{Cs}^{\delta+} \mathrm{F}\right]$ must be examined to explain the change in $\mathrm{CF}_{3} \mathrm{OF}$ yield. This situation will be estimated from XPS analysis of the CsF used for the reaction. The binding energy of the $\mathrm{F} 1 \mathrm{~s}$ electron on the CsF surface was analyzed using XPS (Fig. 1.12). After the reaction, the XPS profile of $\mathrm{F}$ 1s electron shows a peak at $687.1 \mathrm{eV}$ that corresponds to the $\mathrm{C}-\mathrm{F}$ bond. The XPS profile after etching has a peak at $684.3 \mathrm{eV}$ that corresponds to CsF. Results showed that the organic compounds including $\mathrm{C}-\mathrm{F}$ bond were adsorbed onto the $\mathrm{CsF}$ surface. These organic compounds must be intermediates.

On the other hand, it is considered that the radical [34] reaction must contribute to the increased $\mathrm{CF}_{3} \mathrm{OF}$ yield at temperatures of 373-473 K. However, comparing Fig. 1.13 with Fig. 1.14 at $498 \mathrm{~K}$, the radical reaction must only slightly contribute to the increase of the $\mathrm{CF}_{3} \mathrm{OF}$ yield. Fig. 1.14 shows that the yields of $\mathrm{COF}_{2}$ and $\mathrm{CF}_{3} \mathrm{OF}$ decreased over $473 \mathrm{~K}$. That is, they have a maximum value around $474 \mathrm{~K}$. With the change of the reaction temperature, it seems that the kinds of the reaction intermediates change on the $\mathrm{CsF}$ surface. At low temperatures, the possible reaction intermediates of $\left[\mathrm{CF}(\mathrm{O}) \mathrm{O}^{\delta-}\right.$ $\left.\mathrm{Cs}^{\delta+} \mathrm{F}\right]$ and $\left[\mathrm{CF}_{2}(\mathrm{OF}) \mathrm{O}^{\delta-} \mathrm{Cs}^{\delta+} \mathrm{F}\right]$ must be formed by reactions (12)-(14); $\mathrm{CF}_{2}(\mathrm{OF})_{2}$ is formed dominantly at room temperature. The $\mathrm{COF}_{2}$ and $\mathrm{CF}_{3} \mathrm{OF}$ must be formed dominantly from the reaction intermediates by reactions (15)-(21) at temperatures of 373-473 K. The formation of $\mathrm{CF}_{3} \mathrm{OF}$ becomes dominant. At temperatures greater than $498 \mathrm{~K}$, the reaction through the possible intermediate $\left[\mathrm{CF}_{3} \mathrm{O}^{\delta-} \mathrm{Cs}^{\delta+} \mathrm{F}\right]$ will become 
dominant. Furthermore, some reactions exist in which the possible reaction intermediates of $\left[\mathrm{CF}(\mathrm{O}) \mathrm{O}^{\delta-} \mathrm{Cs}^{\delta+} \mathrm{F}\right],\left[\mathrm{CF}_{2}(\mathrm{OF}) \mathrm{O}^{\delta-} \mathrm{Cs}^{\delta+} \mathrm{F}\right]$ and $\left[\mathrm{CF}_{3} \mathrm{O}^{\delta-} \mathrm{Cs}^{\delta+} \mathrm{F}\right]$ might undergo competing reactions to give different products such as $\mathrm{COF}_{2}, \mathrm{CF}_{3} \mathrm{OF}, \mathrm{CF}_{4}$ and $\mathrm{CF}_{3} \mathrm{OOCF}_{3}$.

$\mathrm{CF}_{3} \mathrm{OOCF}_{3}$ is formed by the following reaction:

$$
2\left[\mathrm{CF}_{3} \mathrm{O}^{\delta-} \mathrm{Cs}^{\delta+} \mathrm{F}\right] \rightarrow \mathrm{CF}_{3} \mathrm{OOCF}_{3}+\mathrm{CsF}
$$

As inferred from the results shown in Fig. 1.14, reaction (22) must take place significantly at temperatures greater than $473 \mathrm{~K}$. Yields of $\mathrm{CF}_{3} \mathrm{OF}$ might decrease because of the consumption of $\left[\mathrm{CF}_{3} \mathrm{O}^{\delta-} \mathrm{Cs}^{\delta+} \mathrm{F}\right]$ by reaction (22). Table 1 shows that $\mathrm{CF}_{3} \mathrm{OOCF}_{3}$ was also produced at $303 \mathrm{~K}$ in $0.1 \%$. This fact can not be explained using the reaction scheme described above. There is probably a reaction path way through which $\mathrm{CF}_{3} \mathrm{OOCF}_{3}$ is produced from $\mathrm{CF}_{2}(\mathrm{OF})_{2}$, which is the major product at $303 \mathrm{~K}$.

The formation of $\mathrm{CF}_{4}$ described by reaction (23) scarcely occurred, as shown in Fig. 1.14:

$$
\left[\mathrm{CF}_{3} \mathrm{O}^{\delta-} \mathrm{Cs}^{\delta+} \mathrm{F}\right]+\mathrm{F}_{2} \rightarrow \mathrm{CF}_{4}+\mathrm{O}_{2}+\mathrm{CsF}
$$

As described above, it became the possible major intermediate instead of $\left[\mathrm{CF}_{2}(\mathrm{OF}) \mathrm{O}\right.$ ${ }^{\delta-} \mathrm{Cs}^{\delta+} \mathrm{F}$ ] at temperatures greater than $473 \mathrm{~K}$. It is easily converted to $\mathrm{CF}_{3} \mathrm{OF}$ and $\mathrm{CF}_{3} \mathrm{OOCF}_{3}$ because $\left[\mathrm{CF}_{3} \mathrm{O}^{\delta-} \mathrm{Cs}^{\delta+} \mathrm{F}\right]$ must react with $\mathrm{F}_{2}$ to generate $\mathrm{CF}_{4}$. The reactions (21) and (22) proceed rapidly more than reaction (23), thereby giving low $\mathrm{CF}_{4}$ yield. The competitive reaction processes mentioned here are summarized in scheme 2 . 


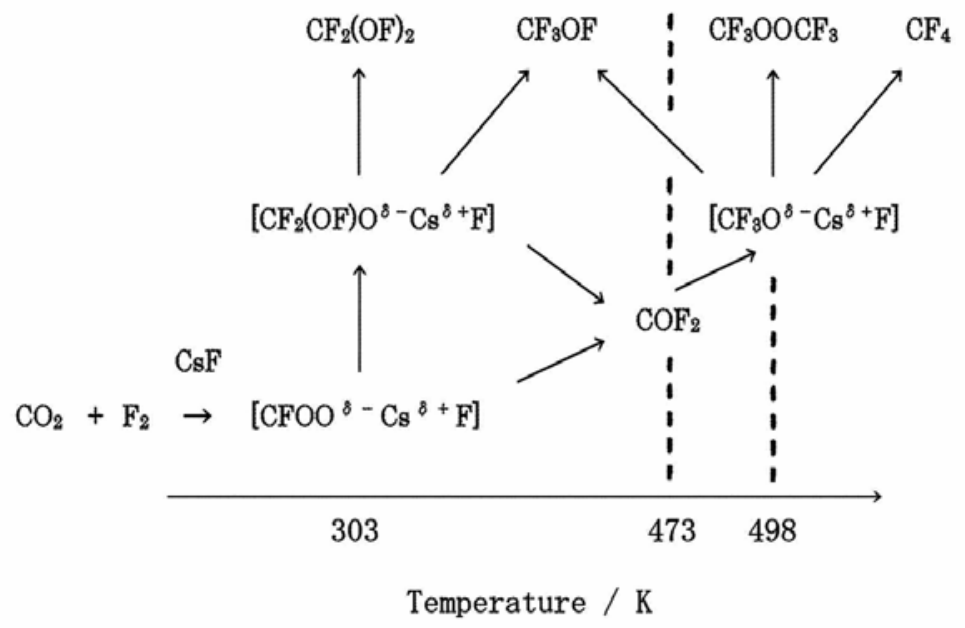

Scheme 2. Scheme of competitive reaction processes. Blanketed compounds are the possible intermediates.

\section{References and notes}

[1] J. C. Amphlett, J. R. Dacey, G. O. Pritchard, J. Phys. Chem. 75 (1971) 3024-3026.

[2] G. H. Cady, Inorg. Synth. 8 (1966) 165-170.

[3] Kwasnik in handbook of Preparative Inorganic Chemistry, Vol.1, G. Brauer, Ed. (Academic Press Inc., New York, 2th ed., (1963) pp. 206-208.

[4] F. A. Hohorst, J. M. Shreeve, J. Am. Chem. Soc. 89 (1966) 1809-1810.

[5] R. L. Cauble, G. H. Cady, J. Am. Chem. Soc. 89 (1967) 1962.

[6] R. L. Cauble, G. H. Cady, J. Am. Chem. Soc. 89 (1967) 5161-5162.

[7] P. Politzer, J. Am. Chem. Soc. 91 (1969) 6235-6237.

[8] The Entrance of Fluorine Chemistry, 155 Committee of Fluorine Chemistry. (Printed in Japan, 1999) 
[9] Satoshi Ueda, Yasuo Hasegawa, Susumu Yonezawa, Masayuki Takashima, International Chemical Congress of Pacific Basin Societies, Honolulu, Hawaii, December, 2000, Book of Abstracts, P. 1487.

[10] R. Otani, S. Yonezawa, M. Takashima, Master Dissertation (2002).

[11] Yasuo Hasegawa, Reiko Otani, Susumu Yonezawa, Masayuki Takashima, J. Fluorine Chem. 128 (2007) 17-28.

[12] Gregor Hoogers, Fuel Cell Technology Handbook (CRC press, 2003).

[13] W. M. Latimer, The Oxidation States of the Elements and Their Potentials in Aqueous Solutions (Prentice Hall, New York, 1952).

[14] P. G. Thompson, J. Am. Chem. Soc. 89 (1966) 1811-1813.

[15] A. J. Arvia, P. J. Aymonino, Spectrochim. Acta 18 (1962) 1299-1309.

[16] R. S. Porter, G. H. Cady, J. Am. Chem. Soc. 79 (1957) 5628-5631.

[17] A. H. Nielsen, T. G. Burke, P. J. H. Woltz, E. A. Jones, J. Chem. Phys. 20 (1952) $596-604$.

[18] Private communication with Central Glass Co. Ltd. for $\mathrm{COF}_{2}$ : FT-IR(CaF 2 ): $\mathrm{cm}^{-1},(\mathrm{~T} \%): 1957 \mathrm{vs}(32 \%), 1943 \mathrm{vs}(25 \%), 1929 \mathrm{vs}(23 \%), 1256 \mathrm{vs}(24 \%), 1231 \mathrm{vs}(23 \%)$, $977 \mathrm{~s}(70 \%)$ and $959 \mathrm{~s}(70 \%)$.

[19] R. T. Legemann, E. A. Jones, P. J. Woltz, J. Chem. Phys. 20 (1952) 1768-1771.

[20] Selected data for $\mathrm{CF}_{4}: \mathrm{FT}-\mathrm{IR}\left(\mathrm{CaF}_{2}, \mathrm{~cm}^{-1}\right): 1280 \mathrm{vs} ; \mathrm{EI}-\mathrm{MS}: \mathrm{m} / \mathrm{z}(\%): 69\left(\mathrm{CF}_{3}{ }^{+}, 100\right)$, 50( $\left.\mathrm{CF}_{2}{ }^{+}, 10\right) ;$ CI-MS: m/z(\%): 69([M-19] $\left.{ }^{+}, 100\right), 89\left(\mathrm{M}+\mathrm{H}^{+}, 6\right)$.

[21] Selected data for $\mathrm{COF}_{2}: \mathrm{FT}-\mathrm{IR}\left(\mathrm{CaF}_{2}, \mathrm{~cm}^{-1}\right): 1957 \mathrm{vs}, 1943 \mathrm{vs}, 1929 \mathrm{vs}, 1256 \mathrm{vs}, 1231 \mathrm{vs}$, 977s and 959s; EI-MS: m/z(\%): 47( $\left.\mathrm{COF}^{+}, 100\right), 66\left(\mathrm{COF}_{2}{ }^{+}, 60\right)$; CI-MS: 67(M+H+ $\left.{ }^{+}, 100\right)$, $47\left([\mathrm{M}-19]^{+}, 25\right)$.

[22] L. R. Anderson, W. B. Fox, J. Am. Chem. Soc. 89 (1967) 4313-4315.

[23] J. M. Huston, M. H. Studier, J. Fluorine Chem. 13 (1979) 235-249. 
[24] F. A. Hohorst, J. M. Shreeve, Inorg. Synth. 11 (1968) 143-147.

[25] NIST XPS Database (2003).

[26] G. Chiltz, P. Goldfinger, G. Huybrechets, G. Martens, G. Verbeke, Chem. Rev. 63 (1963) 355-372.

[27] G. H. Cady, Anales Asoc. Quim. Argentina 59 (1959) 618.

[28] B. S. Ault, Inorg. Chem. 21 (1982) 756-759.

[29] L. R. Anderson, W. B. Fox, Inorg. Chem. 9 (1970) 2182-2183.

[30] L. Lawlor, J. Passmore, Inorg. Chem. 18 (1979) 2923-2924.

[31] M. Wechsberg, G. H. Cady, J. Am. Chem. Soc. 91 (1969) 4432-4436.

[32] M. E. Redwood, C. J. Willis, Can. J. Chem. 43 (1965) 1893-1898.

[33] M. Lusting, A. R. Pitochelli, J. K. Ruff, J. Am. Chem. Soc. 89 (1967) 2841-2843.

[34] R. F. Merritt, J. Org. Chem. 32 (1967) 4124-4126. 


\section{Chapter 2}

\section{Preparation of $\mathrm{COF}_{2}$ using $\mathrm{CO}_{2}$ and $\mathrm{F}_{2}$ in the electrochemical cell with $\mathrm{PbSnF}_{4}$ as a solid electrolyte}

\subsection{Introduction}

On the earth each year, 12,100 million tonnes of $\mathrm{CO}_{2}$ are emitted to the air [1]. The increase of its concentration in the air is causing global warming. Numerous efforts have been made to remove $\mathrm{CO}_{2}$ from the air. Normally, new methods to reduce $\mathrm{CO}_{2}$ to $\mathrm{CH}_{3} \mathrm{OH}$ and $\mathrm{CH}_{4}$ have been investigated [2-3]. These investigations are based on the concept that $\mathrm{CO}_{2}$ is a final product of hydrocarbon compounds' combustion.

A strong oxidant, $\mathrm{F}_{2}$, can oxidize the oxides. Previously, we reported a reaction between $\mathrm{CO}_{2}$ and $\mathrm{F}_{2}$ to form $\mathrm{COF}_{2}$ [4]. By this reaction, $\mathrm{CO}_{2}$ can be converted to $\mathrm{COF}_{2}$. The Gibbs free energy change of this reaction is calculated as $220 \mathrm{~kJ} \mathrm{~mol}^{-1}$ [5].

$$
\mathrm{CO}_{2}+\mathrm{F}_{2} \rightarrow \mathrm{COF}_{2}+1 / 2 \mathrm{O}_{2}+(-\Delta \mathrm{G}) 220 \mathrm{~kJ} \mathrm{~mol}^{-1}
$$

Furthermore, the theoretical electromotive force calculated from its Gibbs free energy is $1.14 \mathrm{~V}$, which value is mostly equal to the electromotive force $1.23 \mathrm{~V}$ of the $\mathrm{H}_{2}$ / $\mathrm{O}_{2}$ fuel cell [6]. Based on this idea, we tried to investigate $\mathrm{COF}_{2}$ formation using $\mathrm{CO}_{2}$ and $\mathrm{F}_{2}$ in the electrochemical cell with $\mathrm{PbSnF}_{4}$. 
By using the electrochemical cell with solid electrolyte to prepare $\mathrm{COF}_{2}$, the reaction between $\mathrm{CO}_{2}$ and $\mathrm{F}_{2}$ might be controlled by external current flow and the separation of $\mathrm{COF}_{2}$ from $\mathrm{CO}_{2} / \mathrm{F}_{2}$ mixture gas is not needed.

Tetragonal $\mathrm{PbSnF}_{4}$ [7-22] is known as a fluoride ion conductor having high electric conductivity at ambient temperatures. $\mathrm{PbSnF}_{4}$ can exist in several polymorphic forms as described by many reports $[7,8,14-16]$, and has a very complex system of phase transitions.

The $\mathrm{CO}_{2} / \mathrm{F}_{2}$ electrochemical cell was constructed using tetragonal $\mathrm{PbSnF}_{4}$ as a solid electrolyte and its performance was investigated in detail.

\subsubsection{What is a $\mathrm{CO}_{2} / \mathrm{F}_{2}$ electrochemical cell?}

The electrochemical cell potential is a measure of the maximum amount of energy per unit charge which is available to do work. This maximum work is equal to the change in Gibbs free energy, $\Delta \mathrm{G}$ in the reaction. The ideal performance of a cell is defined by its Nernst potential [23], $E^{p}$, or the ideal cell voltage. The maximum potential difference is called the electromotive force (emf), $E$ emf. The general Nernst equation correlates the Gibbs free energy $\Delta \mathrm{G}$.

For reactions, the net free energy change is directly related to the voltage, and the relationship between free energy change $\Delta \mathrm{G}$ and the cell voltage $\mathrm{E}$ can be expressed as

$$
\begin{aligned}
& \text { Maximum work }=\Delta \mathrm{G}=-n F \Delta E \\
& \Delta E=\Delta E^{\circ}-(R T / n F) \operatorname{In}([\mathrm{Red}] /[\mathrm{Ox}])
\end{aligned}
$$

where $\mathrm{F}$ is the Faraday's constant, $\mathrm{n}$ is the number of electrons transferred in the half-reaction, [Red] is the concentration of the reduced species, and [Ox] is the 
concentration of the oxidized species.

As described above, $\mathrm{CO}_{2}$ can be converted to $\mathrm{COF}_{2}$. Therefore, the theoretical electromotive force calculated from its Gibbs free energy is $1.14 \mathrm{~V}$.

Because of the large reactivity of $\mathrm{F}_{2}$ to $\mathrm{H}_{2} \mathrm{O}$, solid electrolytes [24] are needed. A large number of solid-state materials that exhibit ionic conductivity are known today, and many efforts have been made to understand the ion conduction mechanism at the molecular level. Recently, many fluoride ion conductors have been reported, and $\mathrm{PbSnF}_{4}$ has been used for the design of chemical sensors [20].

\subsubsection{Electrochemical impedance spectroscopy}

To investigate the electrochemical properties of tetragonal $\mathrm{PbSnF}_{4}$, ac impedance spectroscopy is a convenient technique.

The electrochemical reaction at the electrode-electrolyte interface cannot be fully understood using traditional electrochemical measurements. A complete description requires impedance measurement made over a broad frequency range at various potentials and determination of all the electrical characteristics of the interface, which can be though of as a thin capacitor that forms between the charged electrode and the counter ions lined up parallel to it $[25,26]$.

An interface is described by an equivalent circuit. The electrochemical reaction rates are better understood using electrochemical impedance spectroscopy. Scheme 3 shows some components of impedance such as Rb, Rg and Re. 


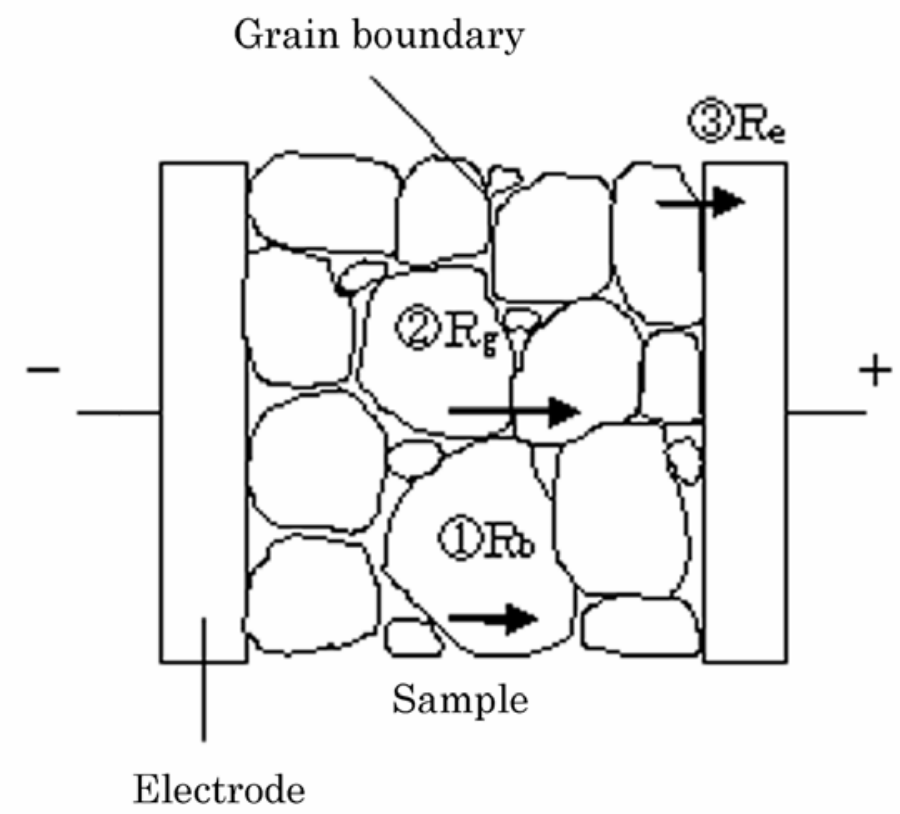

Scheme 3. Some components of electrochemical impedance measurement for solid electrolyte.

In a simple case, the interface can be modeled by an equivalent circuit as shown in Fig. 2.1, also called a Randles circuit [27-29], made of a double-layer [30] capacitor in parallel with a polarization resistor (also known as a charge transfer resistor) and a Warburg impedance.

Impedance is a totally complex resistance encountered when a current flows through a circuit made of resisters, capacitors, or inductors, or any combination of these. The impedance of the interface consists of two parts, a real number $Z$ ' and an imaginary number $Z$ ”with a complex representation. 


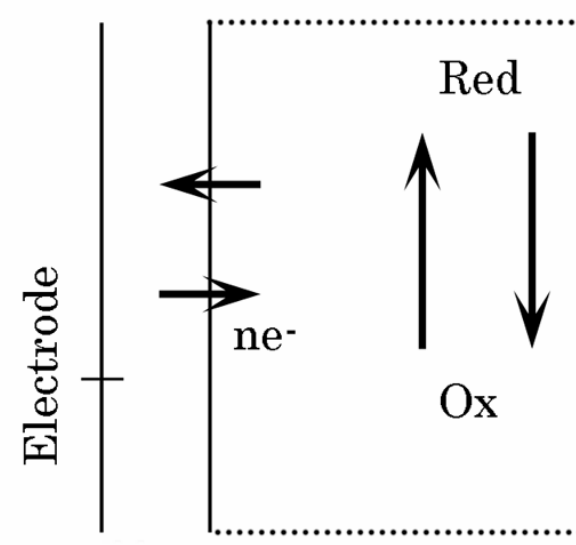

Double Layer

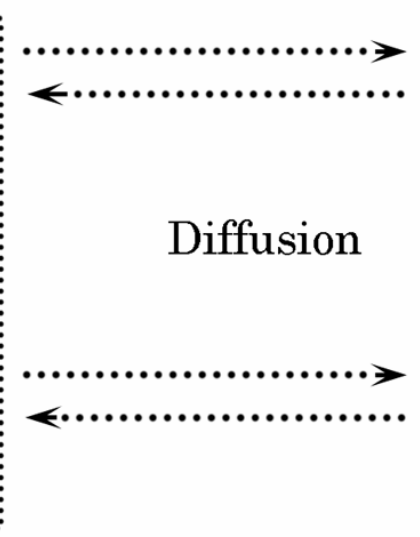

Bulk

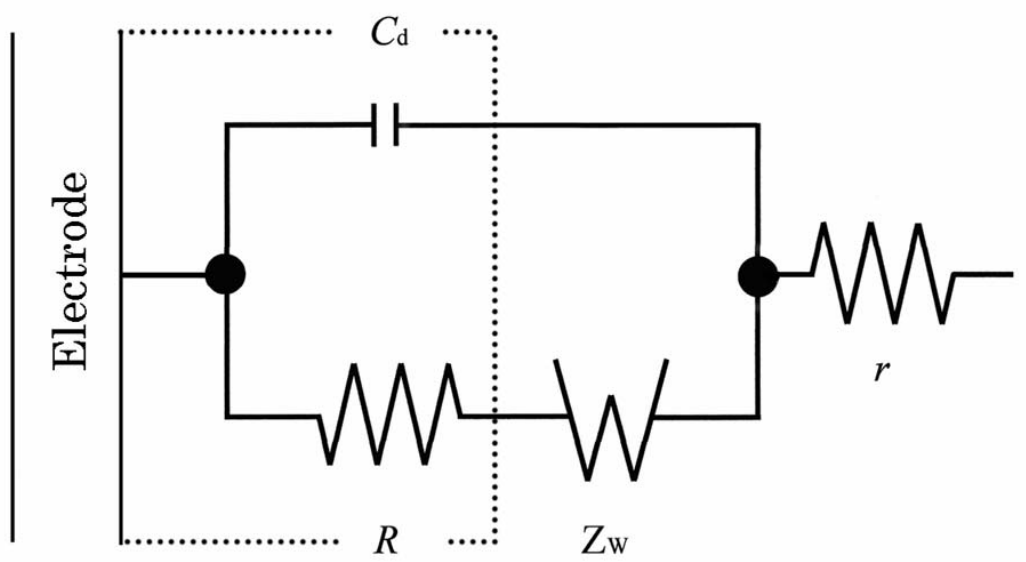

$r \quad$ : Resistanse of cable etc.

$C_{\mathrm{d}}:$ Capacity factor

(Double layer capasitance)

$R \quad$ : Resistance of sample

$Z \mathrm{w}$ : Warburg's impedance

(Charge transfer resistance at inteface)

Fig. 2.1. Randles equivalent circuit and electric components.

Extraction of the system characteristics requires interpreting the Cole-Cole plot (Fig.

2.2) according to following equation. 


$$
\begin{aligned}
& Z(\omega)=r+R /\left(1+j \omega R C_{d}\right)= \\
& \quad r+R /\left(1+\omega^{2} R^{2} C_{d}^{2}\right)-j \omega R^{2} C_{d} /\left(1+\omega^{2} R^{2} C_{d}^{2}\right)=Z^{\prime}+j Z^{\prime}
\end{aligned}
$$

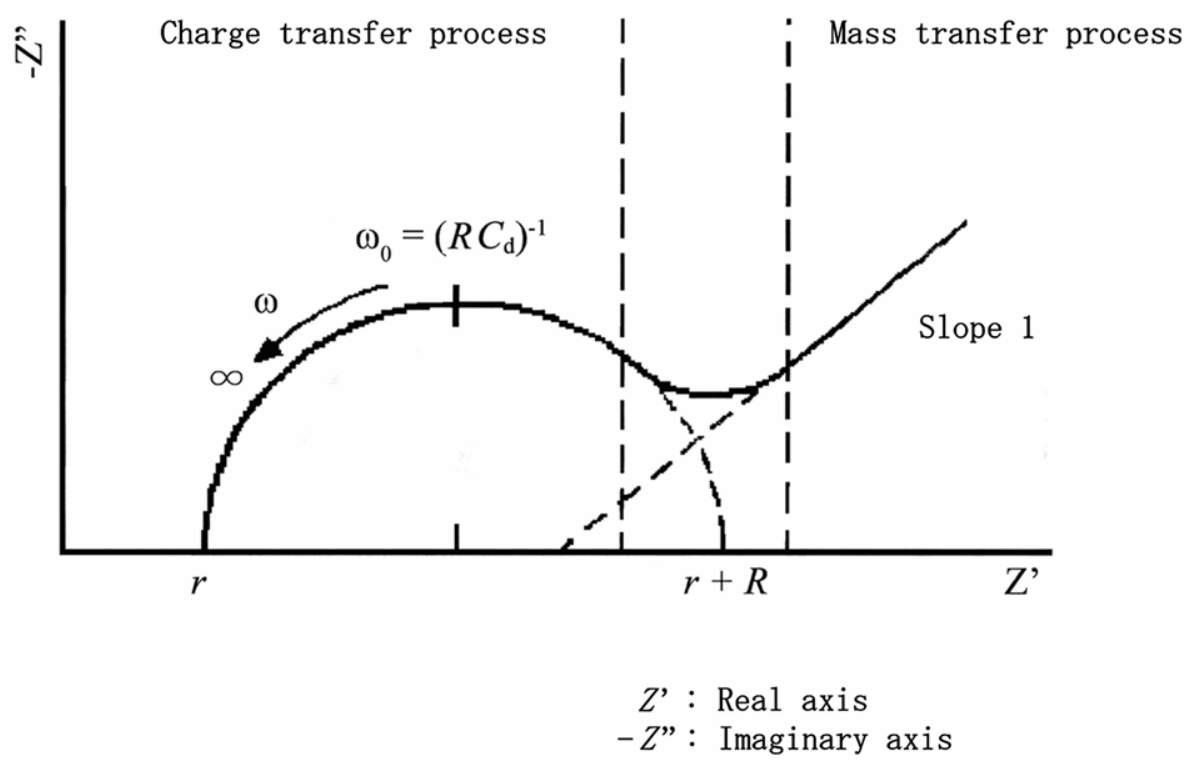

Fig. 2.2. Cole-Cole plot for Randles equivalent circuit.

According to the simulated equivalent circuit, the real and imaginary components of the impedance can be calculated as $Z^{\prime}=r+R /\left(1+\omega^{2} R^{2} C_{d}^{2}\right)$ and $Z^{\prime \prime}=\omega R^{2} C_{d} /(1+$ $\omega^{2} R^{2} C_{d}^{2}$ ), respectively [31].

At high frequencies, the frequency dependent term, $\omega=2 \Pi f$, is high and $\omega^{2} R^{2} C_{d}^{2} \gg 1$, then, $Z(\omega)=Z^{\prime}(\omega)=$ r, $Z$ ’ $(\omega)=1 / \omega C_{d} \fallingdotseq 0$, which is an intercept on the $Z^{\prime}$ axis on the high-frequency side. For $\omega \fallingdotseq 0, Z(\omega)=\mathrm{r}+\mathrm{R}$, which is an intercept on the $Z$ ' axis on the low-frequency side.

This technique will offer the most powerful analysis on the status of electrodes during charging-discharging processes of batteries and electrochemical cells as well as 
corrosion experiments. More importantly, this technique may be used to monitor and prove many different processes that occur during electrochemical experiments, including adsorption of reactants and products as well as various reactions that either precede or follow the experiments, thereby changing the electrical characteristics of electrode-electrolyte interfaces.

In an ideal electrochemical cell, the ionic current through the electrolyte $\left(\mathrm{PbSnF}_{4}\right)$ inside the cell matches an electronic current through an external load. A solid electrolyte acts as a separator of two electrodes as well as a carrier of the internal ionic current. It is in the form of an electrolyte of thickness L and area A (cross-sectional area) that separates electrically the two electrodes of the cell. The electrical conductivity $\left(\sigma_{i}\right)$ can be calculated by following equation.

$$
\sigma_{i}=\mathrm{L} /(\mathrm{R} \times \mathrm{A})
$$

where $\sigma_{i}$ is the ionic conductivity of the electrolyte. For a current $i$ through the cell, the voltage $i \cdot R$ represents a potential drop [8].

The frequency response analyzer (Fig. 2.3) has become the industry standard in electrochemical instrumentation in recent years. The reference ac wave of frequency $\omega$ superimposed on a given dc bias potential is applied to a working electrode in the electrical cell.

The entire frequency range must be scanned by generating ac voltage wave of 10-20 representative frequencies per decade to make measurements. Often, measurements of more than a few ac cycles are necessary at a given frequency to obtain a decent $\mathrm{S} / \mathrm{N}$, and the instrument usually wait for the system to reach a constant current after a step to a desired dc bias potential before it takes measurements. 


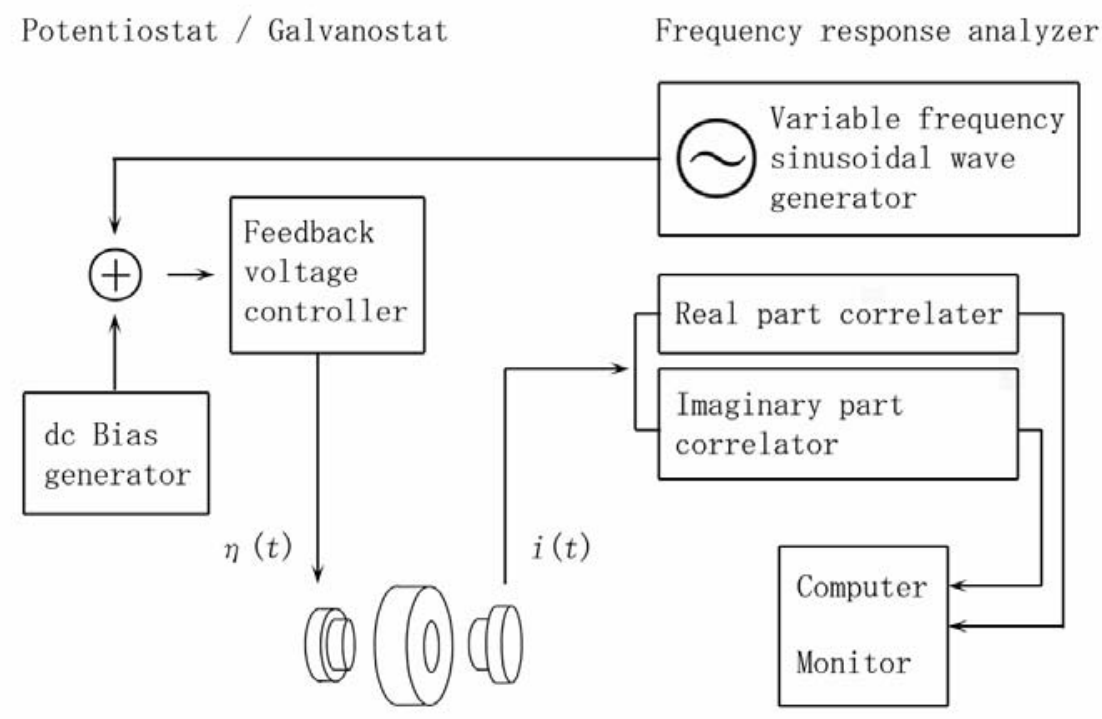

Electrochemical cell

Fig. 2.3. Concept of the frequency response analyzer.

\subsection{Experimental}

\subsubsection{Preparation of $\mathrm{PbSnF}_{4}$}

$\mathrm{PbSnF}_{4}$ was prepared by adding a $1.01 \mathrm{M}$ aqueous solution of $\mathrm{Pb}\left(\mathrm{NO}_{3}\right)_{2}(99.5 \%)$ to a freshly prepared $2.47 \mathrm{M}$ aqueous solution of $\mathrm{SnF}_{2}(99 \%)$ with the ratio of $\mathrm{Pb} / \mathrm{Sn}=0.25$ :

$$
\mathrm{Pb}\left(\mathrm{NO}_{3}\right)_{2}+4 \mathrm{SnF}_{2} \rightarrow \mathrm{PbSnF}_{4}+\mathrm{Sn}\left(\mathrm{NO}_{3}\right)_{2}+2 \mathrm{SnF}_{2}
$$

The white sediment prepared by dropping $\mathrm{Pb}\left(\mathrm{NO}_{3}\right)_{2}$ aqueous solution to $\mathrm{SnF}_{2}$ aqueous solution was suction-filtered and placed in vacuum (ca. $10^{-2} \mathrm{~mm}$ of $\mathrm{Hg}$ ) for at least $4 \mathrm{~h}$. 
Table 2.1

Parameters for preparing $\mathrm{PbSnF}_{4}$ in this study

\begin{tabular}{|c|c|c|}
\hline Parametr & Description & Range \\
\hline & $\mathrm{Pb}\left(\mathrm{NO}_{3}\right)_{2} / \mathrm{SnF}_{2}$ molar ratio in the reaction mixture & 0.25 \\
\hline Time $\left(\mathrm{PbSnF}_{4}\right)$ & $\begin{array}{c}\text { time between the end of the addition of } \mathrm{Pb}\left(\mathrm{NO}_{3}\right)_{2} \\
\text { and the filtration of the product }\end{array}$ & 0 hour \\
\hline $\mathrm{C}\left(\mathrm{SnF}_{2}\right)$ & concentration of $\mathrm{SnF}_{2}$ & $2.47 \mathrm{M}$ \\
\hline $\mathrm{C}\left(\mathrm{Pb}\left(\mathrm{NO}_{3}\right)_{2}\right)$ & concentration of $\mathrm{Pb}\left(\mathrm{NO}_{3}\right)_{2}$ & $1.01 \mathrm{M}$ \\
\hline Gas & atmosphere over the reaction & air \\
\hline Rate & rate of addition of one solution into the other & $0.5 \mathrm{~mL} / \mathrm{min}$ \\
\hline Order & $\mathrm{Pb}\left(\mathrm{NO}_{3}\right)_{2}$ solution is added to the $\mathrm{SnF} \mathrm{F}_{2}$ solution & $\mathrm{Pb}$ in $\mathrm{Sn}$ \\
\hline Temerature & temperature of the reaction & Room Temp. \\
\hline
\end{tabular}

\subsubsection{Characterization of $\mathrm{PbSnF}_{4}$}

The sample was characterized using X-ray diffraction (XRD) and analyzed by energy dispersive X-ray fluorescence spectrometry (XFS), density measurement, and quantitative analysis of fluoride ion.

Using XFS (EDX-800; Shimadzu Corp.), a calibration curve was plotted for quantitative analysis of samples. The molar ratios of $\mathrm{PbF}_{2}$ and $\mathrm{SnF}_{2}$ in pellets as standard samples were adjusted to $1: 0,1: 4,2: 3,3: 2,4: 1$, and $0: 1$. Density was measured (Micrometics Accupyc 1330; Shimadzu Corp.).

A fluoride-ion-selective electrode (SA720; Orion Research Inc.) and ion chromatography (Tosoh Corp.) were used for quantitative analyses of fluoride ions.

The spacing of atoms in a solid can be measured using X-rays. X-ray diffraction data were collected using a diffractometer (XD-3As; Shimadzu Corp.) with $\mathrm{Cu} \mathrm{K} \alpha$ radiation (1.5418 ̊̊). Data were collected at a scan rate of $2^{\circ} / \mathrm{min}$ by sampling pitch $0.034^{\circ}$, with 
a preset time of $4 \mathrm{~s}$. Rietveld analyses of the X-ray power diffraction pattern were carried out. The crystal structure parameters were refined using Rietveld analysis with the RIETAN-2000 program [32].

The sample of about $1 \mathrm{~g}$ was compacted into a pelleter. After vacuuming for $15 \mathrm{~min}$, the sample was pelletized to $13 \mathrm{~mm} \varphi \times 1 \mathrm{~mm}$ under the condition of $4.5 \mathrm{MPa}$ for $5 \mathrm{~min}$. Gold electrodes were vapor-deposited with cross-sectional area of $28.3 \mathrm{~mm}^{2}$ on both surfaces of the $\mathrm{PbSnF}_{4}$ pellet using an ion coater (IC-50; Shimadzu Corp.).

The pellet was set in a cell assembly that was designed specially to measure the electrical conductivity, as shown in Fig. 2.4; the pellet was sandwiched and pressed between two Pt electrodes. The electrical conductivity was measured using ac impedance method (Frequency Response Detector Model 1025, Potentiostat / Galvanostat Model 273A; EG \& G Instruments). This measurement was done for frequencies of $500 \mathrm{kHz}$ and $1 \mathrm{~Hz}$. Temperature variations of ac conductivities were recorded for temperatures of $286-473 \mathrm{~K}$. The polarization current was recorded as a function of time and was recorded using a computerized data acquisition system. The ac conductivities depicted the Arrhenius behavior of $\mathrm{PbSnF}_{4}$ using a temperature variation setup.

The ion transport number of the sample was estimated using Wagner's dc polarization method [33]. Before dc polarization measurement, the electrical conductivity of the sample in argon was measured. After heating to an appropriate temperature, voltage was applied and the leak current was measured using chronoamperometry (Potentiostat / Galvanostat Model 273A; EG \& G Instruments) using the same setup. The steady volt-ampere characteristics of the specimen were also measured. Partial electron hole and electronic conductivities were obtained. Then, the electronic transport number was calculated. 


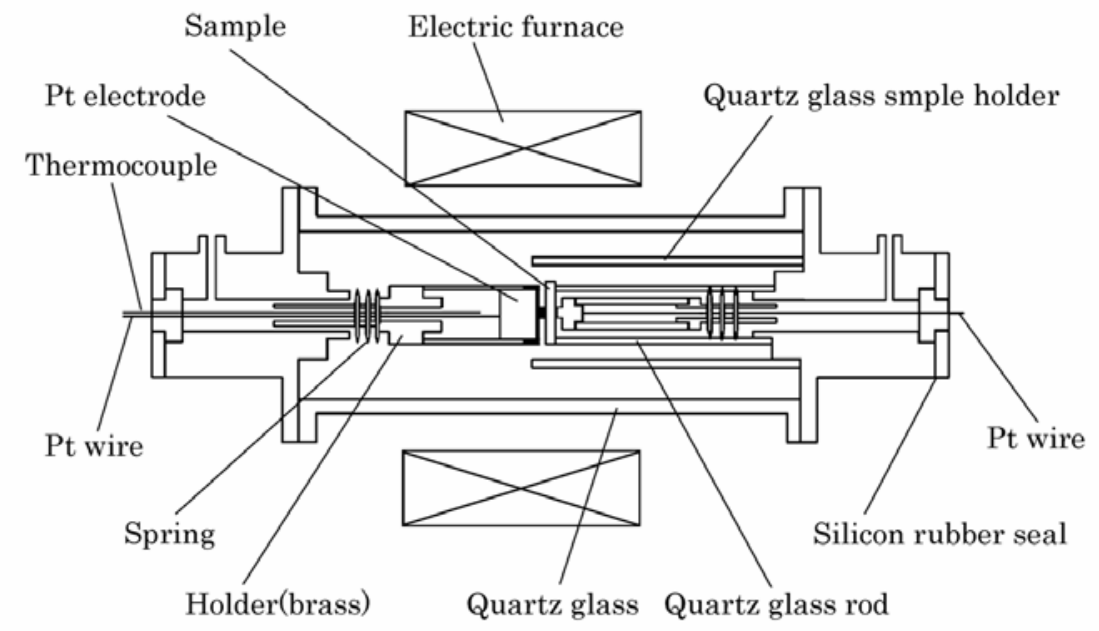

Fig. 2.4. Schematic illustration of the original designed cell.

\subsubsection{Preparation of $\mathrm{COF}_{2}$}

Fig. 2.5 is an image of a $\mathrm{CO}_{2} / \mathrm{F}_{2}$ electrochemical cell. It is expected that the electrochemical cell would be applied at a low temperature by our research.

$\mathrm{A} \mathrm{CO}_{2} / \mathrm{F}_{2}$ electrochemical cell was constructed using a reactive line and an original cell for electromotive force measurement. $\mathrm{A} \mathrm{PbSnF}_{4}$ disk was prepared for the electromotive force measurement. A sample of about $2.5 \mathrm{~g}$ was compacted into a pelleter. After vacuuming for $15 \mathrm{~min}$, the sample was pelletized to $20 \mathrm{~mm} \varphi \times 1.2 \mathrm{~mm}$ under 9.5 $\mathrm{MPa}$ for $5 \mathrm{~min}$. The relative density of the pellet of the $\mathrm{PbSnF}_{4}$ prepared here was about 0.87 . 


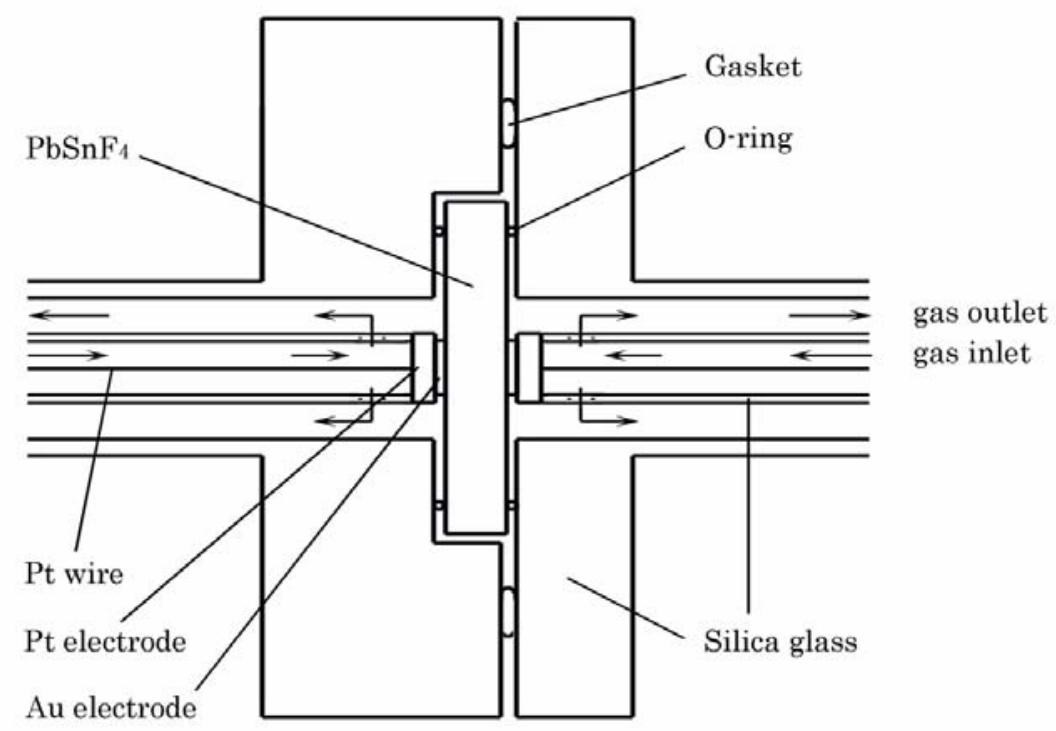

Fig. 2.5. Schematic diagram of the $\mathrm{CO}_{2} / \mathrm{F}_{2}$ electrochemical cell.

The pellet was polished and a porous Au electrode was vapor-deposited onto the $\mathrm{PbSnF}_{4}$ pellet surface. Fig. 2.5 shows that the pellet was set in a cell assembly designed specially to measure the electromotive force. In addition, the cell was connected to an original line, as shown in Fig. 2.6.

The $\mathrm{CO}_{2}$ and $\mathrm{F}_{2}$ in $\mathrm{Ar}$, Argon balance, were put in the cell, respectively, in $0.1 \mathrm{MPa}$ and the electromotive force was measured. That arrangement produced a closed circuit and the current was measured when the electromotive force was steady.

The $\mathrm{CO}_{2}$ gas of the anode side was put in an IR cell after the current had been measured in the closed circuit for three hours at $373 \mathrm{~K}$. The gaseous product at the anode was analyzed using FT-IR spectroscopy. 


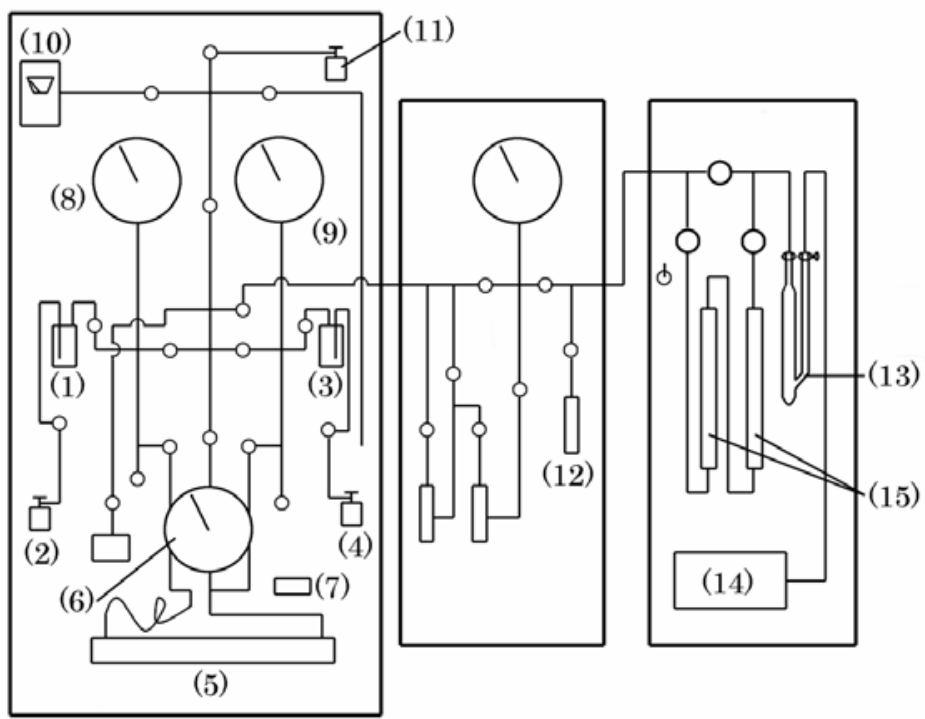

Fig. 2.6. Schematic diagram of original line for electromotive force measurement. (1) $\mathrm{CO}_{2}$ gas storage, (2) $\mathrm{CO}_{2}$ gas cylinder, (3) $\mathrm{F}_{2}$ gas storage, (4) $\mathrm{F}_{2}$ gas cylinder, (5) cell for electromotive force, (6) $\mathrm{F}_{2}$ gas pressure gauge, (7) $\mathrm{F}_{2}$ gas pressure digital gauge, (8) $\mathrm{CO}_{2}$ gas pressure gauge, (9) $\mathrm{F}_{2}$ gas pressure gauge, (10) PIRANI gauge, (11) Ar gas cylinder, (12) gas sampler, (13) trap (liquid $\mathrm{N}_{2}$ ), (14) vacuum pump (oil rotary), and (15) activated alumina.

\subsection{Results and discussion}

\subsubsection{Preparation of $\mathrm{PbSnF}_{4}$}

A synthesis on the $\mathrm{MF}_{2}-\mathrm{SnF}_{2}$ systems in both aqueous and molten states was carried out by Donaldson and Senior [7]. There are two known main routes to prepare $\mathrm{PbSnF}_{4}$ from solution and by direct reaction at high temperature [7-12].

White sediment was prepared by mixing a $\mathrm{Pb}\left(\mathrm{NO}_{3}\right)_{2}$ aqueous solution and $\mathrm{SnF}_{2}$ 
solution. The dropping speed was 10 or $500 \mathrm{~mm}^{3} \mathrm{~s}^{-1}$. The hold time after mixing two solutions was $0-24 \mathrm{~h}$. The $\left(\begin{array}{lll}0 & 0 & \ell\end{array}\right)$ peak of tetragonal $\mathrm{PbSnF}_{4}$ became larger with increasing hold time after mixing. It was suitable to prepare tetragonal $\mathrm{PbSnF}_{4}$ at dropping speed $500 \mathrm{~mm}^{3} \mathrm{~s}^{-1}$ further than dropping speed $10 \mathrm{~mm}^{3} \mathrm{~s}^{-1}$. Fig. 2.7 shows the XRD results of the synthesized sample at various temperatures at a dropping speed $500 \mathrm{~mm}^{3} \mathrm{~s}^{-1}$. The Miller indices are shown in Fig. 2.7.

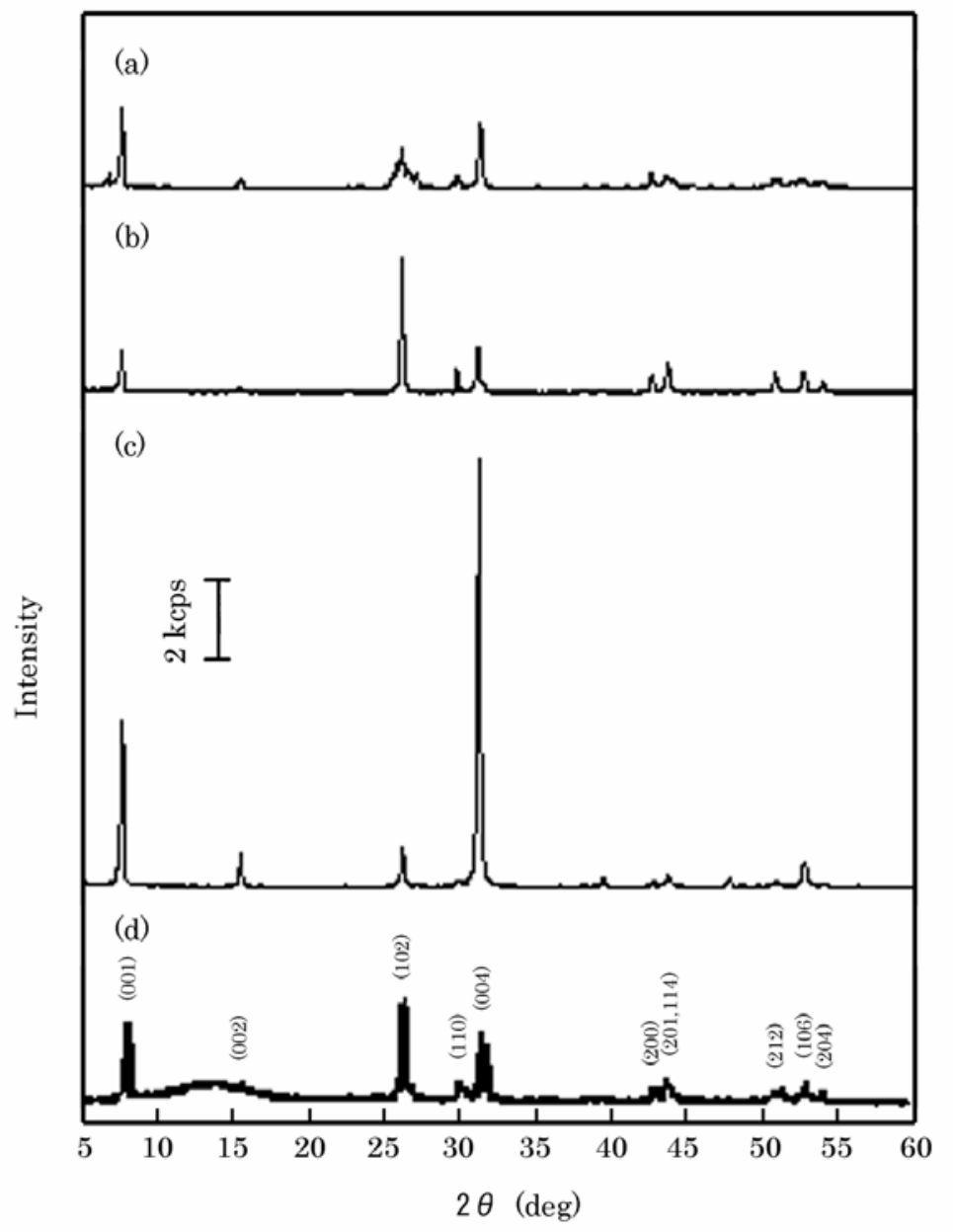

Fig. 2.7. XRD profiles of $\mathrm{PbSnF}_{4}$ prepared at $273 \mathrm{~K}(\mathrm{a}), 298 \mathrm{~K}(\mathrm{~b})$ and $333 \mathrm{~K}$ (c), and reference (d). 
Compared with Fig. 2.7(d) referred from the literature [11, 22, 34], a new peak was observed at $2 \theta=6.9^{\circ}$; the ( $\left(\begin{array}{lll}1 & 0 & 2\end{array}\right)$ peak shape was broad at about $273 \mathrm{~K}$. The $\left(\begin{array}{lll}1 & 1 & 0\end{array}\right)$ peak was almost lost, and the $(00 \ell)$ peaks had strengthened at about $333 \mathrm{~K}$, and new small peaks were observed at $2 \theta=39.5^{\circ}$ and $47.8^{\circ}$. In this study, we obtained tetragonal $\mathrm{PbSnF}_{4}$, as reported in Ref. [11], through preparation at room temperature.

Fig. 2.8 shows the profile of Rietveld refinement. The solid line in the profile was calculated using the RIETAN-2000 program [32]; the dotted line indicates data observed by XRD. The structure was determined in the tetragonal space group $P 4 / \mathrm{nmm}$, with $a_{\mathrm{o}}=0.4217 \mathrm{~nm}, c_{\mathrm{o}}=1.1427 \mathrm{~nm} ; R_{\mathrm{F}}$ was 7.09 . This value was insufficiently small; some orthorhombic phase existed in the product.

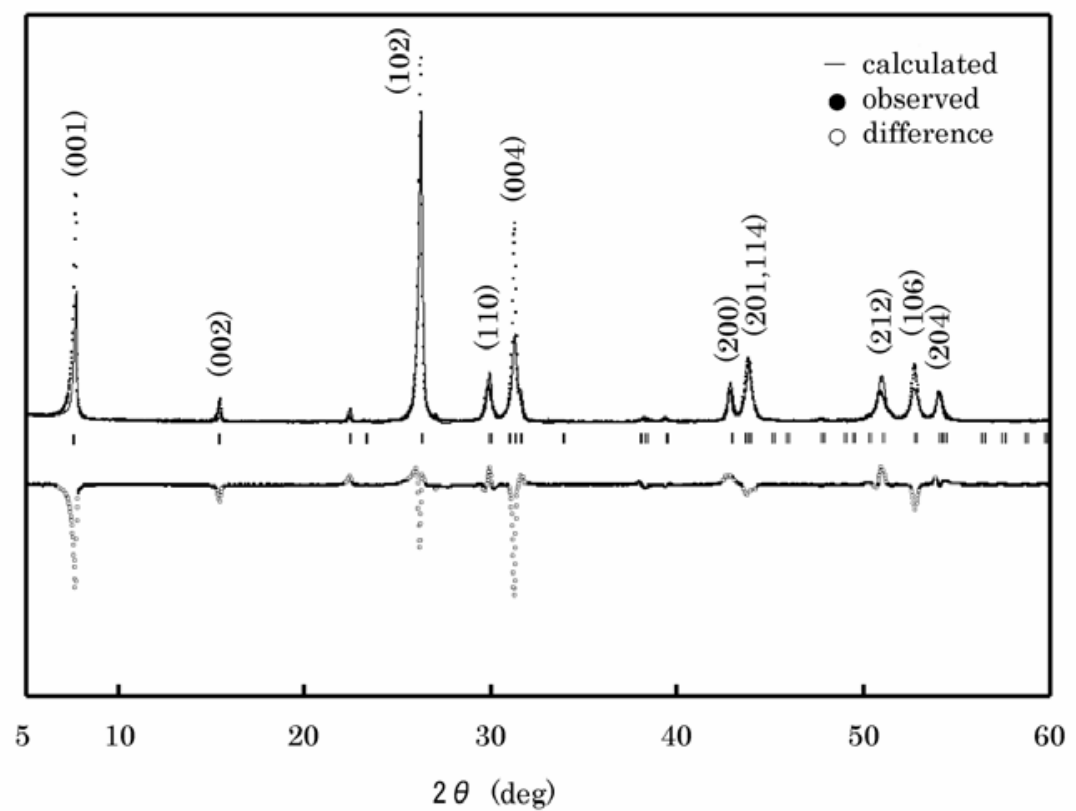

Fig. 2.8. Rietveld refinement profile of $\mathrm{PbSnF}_{4}$. (-: calculated, observed, $\bigcirc$ : difference), $R_{\mathrm{F}}=7.09, S=9.1397$. 
A schematic illustration of the crystal lattice is shown in Fig. 2.9. Both $\mathrm{Pb}^{2+}$ and $\mathrm{Sn}^{2+}$ are ordered in the lattice. This ordering of $\mathrm{Pb}$ and $\mathrm{Sn}$ causes formation of vacancies of fluoride ion at the $4 \mathrm{f}$ and $8 \mathrm{i}$ site. Fluoride ions were transferred through these sites. Crystal parameters and interatomic distances are summarized in Tables 2.2 and 2.3. The theoretical density obtained from Rietveld refinement was $6.588 \mathrm{~g} \mathrm{~cm}^{-3}$ and the experimental density was $6.559 \mathrm{~g} \mathrm{~cm}^{-3}$. The difference between the theoretical and experimental densities was $0.44 \%$, which was considerably small.

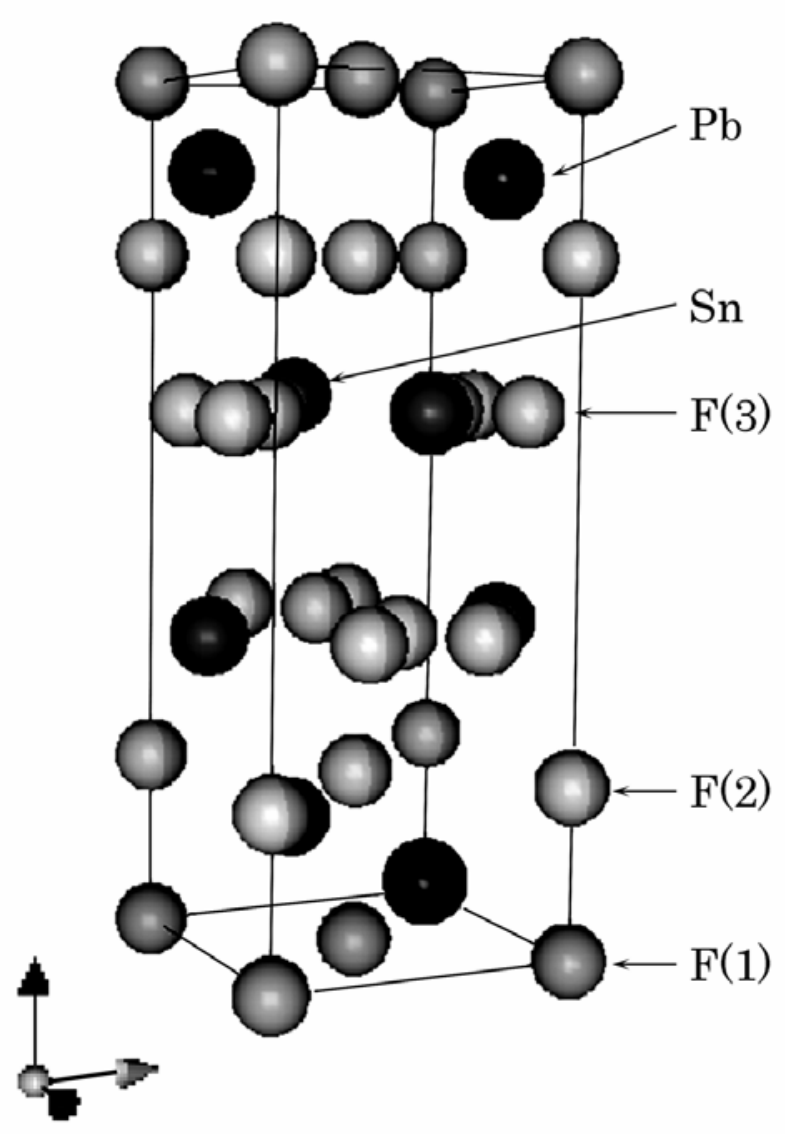

Fig. 2.9. Unit lattice of tetragonal $\mathrm{PbSnF}_{4} . a_{\mathrm{o}}=0.4217 \mathrm{~nm}, c_{\mathrm{o}}=1.1427 \mathrm{~nm}$, Space group $P 4 / \mathrm{nmm}$. 
On the other hand, the prepared sample was estimated, respectively, as $\mathrm{Pb}_{1.2} \mathrm{SnF}_{3.9}$, $\mathrm{PbSnF}_{3.86-4.08}$ and $\mathrm{PbSnF}_{3.8}-4.12$ using $\mathrm{X}$-ray fluorescence spectroscopy (XFS), fluoride ion-selective electrode, and ion chromatography.

Table 2.2

Atomic parameter by Rietveld analysis of $\mathrm{PbSnF}_{4}$

\begin{tabular}{llllll}
\hline Atom & Site & $\mathrm{x}$ & $\mathrm{y}$ & $\mathrm{z}$ & Occupancy \\
\hline $\mathrm{Pb}$ & $2 \mathrm{c}$ & 0 & 0.5 & 0.10995 & 1.0 \\
$\mathrm{Sn}$ & $2 \mathrm{c}$ & 0 & 0.5 & 0.63036 & 1.0 \\
$\mathrm{~F} 1$ & $2 \mathrm{a}$ & 0.5 & 0.5 & 0 & 1.0 \\
$\mathrm{~F} 2$ & $4 \mathrm{f}$ & 0.5 & 0.5 & 0.2011 & 0.56 \\
$\mathrm{~F} 3$ & $8 \mathrm{i}$ & 0 & 0.30901 & 0.37891 & 0.47 \\
\hline
\end{tabular}

$V=2.032 \times 10^{-28} \mathrm{~m}^{3}, \mathrm{Dx}=6.588 \times 10^{3} \mathrm{~kg} \mathrm{~m}^{-3}$.

Table 2.3

Interatomic distance by Rietveld analysis of $\mathrm{PbSnF}_{4}$

\begin{tabular}{ll}
\hline Bond & Length $(\mathrm{nm})$ \\
\hline $\mathrm{Pb}-\mathrm{F} 1$ & 0.2454 \\
$\mathrm{~Pb}-\mathrm{F} 2$ & 0.2351 \\
$\mathrm{~Pb}-\mathrm{F} 3$ & 0.3177 \\
$\mathrm{~Pb}-\mathrm{Sn}$ & 0.4206 \\
$\mathrm{Sn}-\mathrm{F} 1$ & 0.4720 \\
$\mathrm{Sn}-\mathrm{F} 2$ & 0.2855 \\
$\mathrm{Sn}-\mathrm{F} 3$ & 0.2480 \\
$\mathrm{~F} 1-\mathrm{F} 2$ & 0.2297 \\
$\mathrm{~F} 2-\mathrm{F} 3$ & 0.2413 \\
$\mathrm{~F} 3-\mathrm{F} 3$ & 0.3324 \\
\hline
\end{tabular}




\subsubsection{Electrochemical properties}

Fig. 2.10 shows a Cole-Cole plot of tetragonal $\mathrm{PbSnF}_{4}$ in air. It shows that a semi-circular arc with a tail at the low-frequency range is assignable to electrode interface effects. This type of Cole-Cole plot is analyzed using Randles' equivalent circuit [27-29]. The center of the semi-circle is located below the real axis, which might show the inductance component arise from an experimental problem. At first, the Randles' circuit was inferred to be an equivalent circuit consisting of double-layer capacitance, the charge transfer resistance, and Warburg impedance. However, it seemed that the circuit was more complicated here.

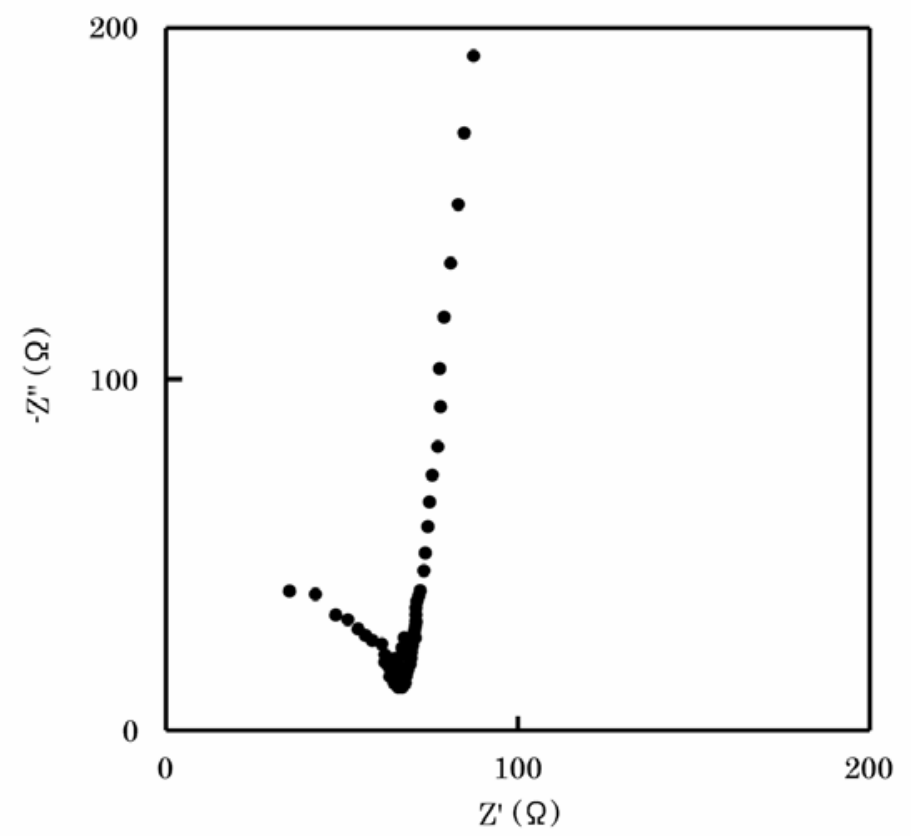

Fig. 2.10. Cole-Cole plot of tetragonal $\mathrm{PbSnF}_{4}$ in air between $1 \mathrm{~Hz}$ and 500

$\mathrm{kHz}$ at $323 \mathrm{~K}$. Sample thickness $=1 \mathrm{~mm}$. 
In this study, a linear part in the Cole-Cole plot was extrapolated to the high-frequency side and the value was regarded as resistance of the sample because factors were not calculable. The value of the extrapolated right crossing point of the impedance spectra to the real axis corresponding to dc resistance was about $65 \Omega$ at 323 $\mathrm{K}$. That is, dc conductivity was calculated as $0.54 \mathrm{Sm}^{-1}$ at $323 \mathrm{~K}$.

Fig. 2.11 shows Arrhenius plots of the electrical conductivity of tetragonal $\mathrm{PbSnF}_{4}$ for temperatures of $286-473 \mathrm{~K}$ in various atmospheres.

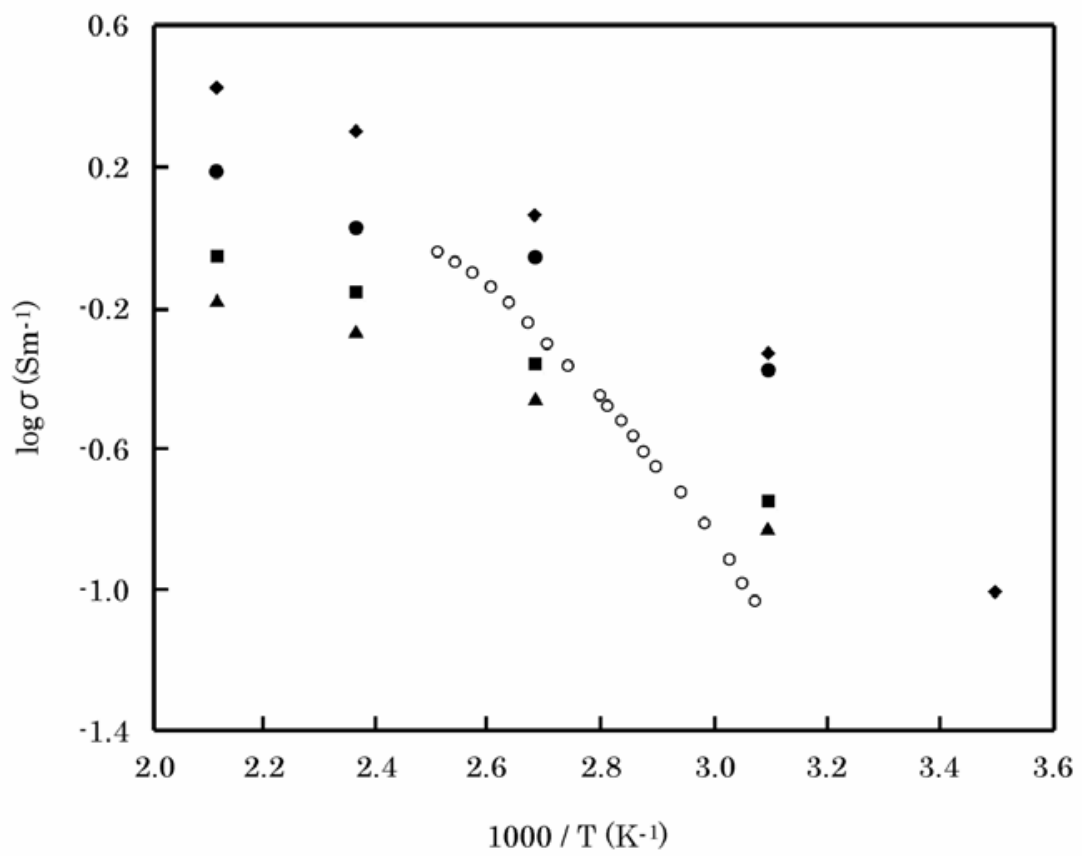

Fig. 2.11. Electrical conductivity of tetragonal $\mathrm{PbSnF}_{4}$ upon cooling from $473 \mathrm{~K}$ to $286 \mathrm{~K}$. (a) In air $(\bullet)$, (b) in vacuum (ם), (c) in $\mathrm{Ar}(\bullet)$ and in Ar flow $(\boldsymbol{\Delta})$, and reference values $(\mathrm{d})(\bigcirc)$. 
A value higher than the reference value in the literature $[11,13,22]$ was obtained in air and Ar. Tetragonal $\mathrm{PbSnF}_{4}$ exhibited the highest conductivity of $3.2 \mathrm{Sm}^{-1}$ at $473 \mathrm{~K}$ in air. The electric conductivity rose with increasing temperature; the Arrhenius plot showed a gradual slope change around $373 \mathrm{~K}$ from the high-temperature range to the low-temperature range in good agreement with the literatures. The activation energies were estimated as $25.0 \mathrm{~kJ} \mathrm{~mol}^{-1}$ at $373-286 \mathrm{~K}$ and $12.4 \mathrm{~kJ} \mathrm{~mol}^{-1}$ at $473-373 \mathrm{~K}$.

The phase transitions in $\mathrm{PbSnF}_{4}$ were already reported around $355 \mathrm{~K}$ [13, 17, 22]. It has been reported that the change in the slope of Arrhenius plots of tetragonal $\mathrm{PbSnF}_{4}$ are found around $355 \mathrm{~K}$ from the high-activation-energy region to the low-activation-energy region in the literatures [8, 17, 22, 35].

Tetragonal $\mathrm{PbSnF}_{4}$ might transform to the other phase, which has lower conductivity. Observed disagreements with values obtained from the literature might result from the different tetragonal $\mathrm{PbSnF}_{4}$ concentration in the sample.

The ionic transport number of mobile species was estimated using Wagner's polarization method [33]. Fig. 2.12 shows the chronoamperogram of $\mathrm{PbSnF}_{4}$ at $373 \mathrm{~K}$. The current observed at $474 \mathrm{~K}$ was not sufficiently stable to carry out measurements. It increased gradually with elapsed time. The current was not well measured at $323 \mathrm{~K}$ either, because the current is so small in this case. At $423 \mathrm{~K}$, the currents used at the steady state were 1.95 and $21.0 \mathrm{nA}$ for applied voltages of 0.1 and $0.5 \mathrm{~V}$, respectively. For $373 \mathrm{~K}$, the currents were 0.38 and $8.13 \mathrm{nA}$ for 0.1 and $0.5 \mathrm{~V}$ of the applied voltages, respectively. Results of chronoamperometry at 423 and $373 \mathrm{~K}$ are summarized in Table 2.4. The total current $i$ includes both ionic and electronic currents. The electrons and holes contribute to the electronic current. The electron transport number $\left(\tau_{\mathrm{e}}\right)$ was obtained using the following equation: 


$$
I /[\exp (u)-1]=R T\left[\sigma_{\mathrm{h}}+\sigma_{\mathrm{e}} \exp (-u)\right] / F L, u=E F / R T
$$

Therein, $I$ is the current density, $F$ the Faraday constant, approximately 96,500 coulombs per equivalent, $L$ the thickness of the sample, $E$ the applied voltage, $\sigma_{\mathrm{h}}$ is the hole conductivity, and $\sigma_{\mathrm{e}}$ is the electron conductivity. The electronic current was carried the electrons mainly because $\sigma_{\mathrm{h}} \ll<\sigma_{\mathrm{e}}$. The electronic conductivities $\left(\sigma_{\mathrm{h}}+\sigma_{\mathrm{e}} \fallingdotseq \sigma_{\mathrm{e}}\right)$ were much smaller than the electrical conductivities of 1.52 and $1.13 \mathrm{Sm}^{-1}(423$ and $373 \mathrm{~K}$ ), respectively. Therefore, the ionic transport number was found to be approximately 1 . The tetragonal $\mathrm{PbSnF}_{4}$ seems to be a good fluoride ion conductor.

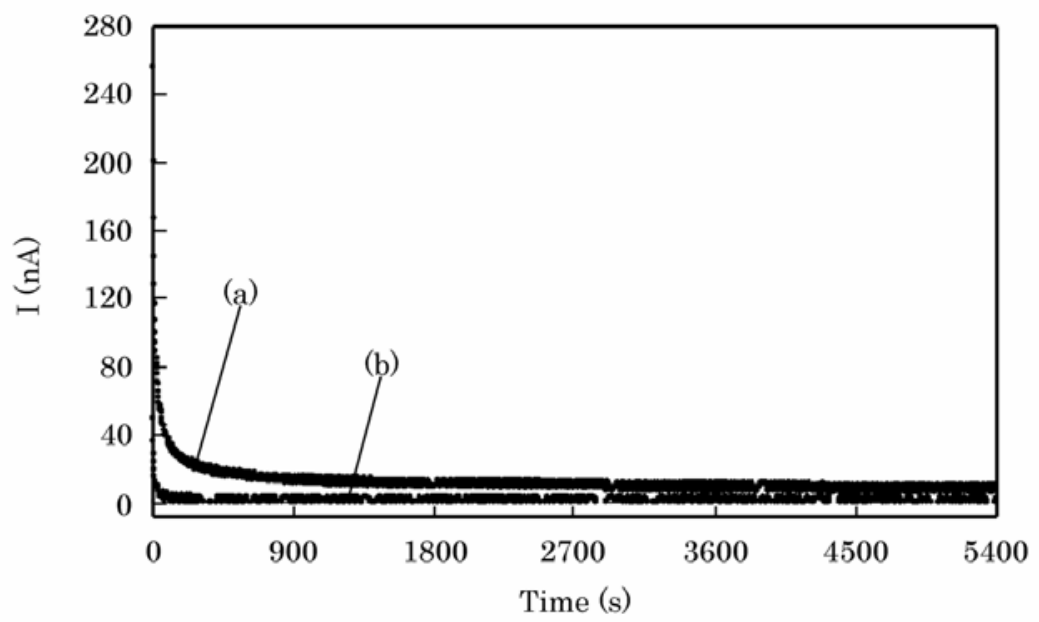

Fig. 2.12. Chronoamperometry for $\mathrm{PbSnF}_{4}$ at $373 \mathrm{~K}$. Applied p.d. $=0.5 \mathrm{~V}$ (a), $0.1 \mathrm{~V}$ (b). Sample thickness $=1 \mathrm{~mm}$. 
Table 2.4

Conductivities taken by electron and hole, $\sigma_{\mathrm{e}}$ and $\sigma_{\mathrm{h}}$ in $\mathrm{PbSnF}_{4}$ at 423 and $373 \mathrm{~K}$

\begin{tabular}{lll}
\hline $\begin{array}{l}\text { Temperature } \\
(\mathrm{K})\end{array}$ & $\begin{array}{l}\text { Electron conductivity, } \\
\sigma_{\mathrm{e}}\left(\mathrm{Sm}^{-1}\right)\end{array}$ & $\begin{array}{l}\text { Hole conductivity, } \\
\sigma_{\mathrm{h}}\left(\mathrm{Sm}^{-1}\right)\end{array}$ \\
\hline 423 & $4.4 \times 10^{-5}$ & $4.4 \times 10^{-10}$ \\
373 & $9.5 \times 10^{-6}$ & $3.2 \times 10^{-11}$ \\
\hline
\end{tabular}

\subsubsection{Preparation of $\mathrm{COF}_{2}$ in an electrochemical cell}

We reported the reaction between $\mathrm{CO}_{2}$ and $\mathrm{F}_{2}$ to form $\mathrm{COF}_{2}$ [4]. By that reaction, $\mathrm{CO}_{2}$ is convertible to $\mathrm{COF}_{2}$. The Gibbs free energy change of this reaction is calculated as -

$220 \mathrm{~kJ} \mathrm{~mol}^{-1}[5]$. The theoretical electromotive force (emf) calculated from its Gibbs free energy is $1.14 \mathrm{~V}$; that value is mostly equal to $1.23 \mathrm{~V}$ of the emf for the $\mathrm{H}_{2} / \mathrm{O}_{2}$ fuel cell [6]:

$$
\mathrm{CO}_{2}+\mathrm{F}_{2} \rightarrow \mathrm{COF}_{2}+1 / 2 \mathrm{O}_{2}+(-\Delta \mathrm{G}) 220 \mathrm{~kJ} \mathrm{~mol}^{-1}
$$

$\mathrm{A} \mathrm{CO}_{2} / \mathrm{F}_{2}$ electrochemical cell was constructed with a tetragonal $\mathrm{PbSnF}_{4}$ disk having $\mathrm{Au}$ electrodes.

The reactions at anodes and cathodes are written as follows:

$$
\begin{array}{ll}
\text { Anode: } & 2 \mathrm{~F}^{-} \rightarrow \mathrm{F}_{2}+2 \mathrm{e}^{-}, \\
& \mathrm{CO}_{2}+\mathrm{F}_{2} \rightarrow \mathrm{COF}_{2}+1 / 2 \mathrm{O}_{2}
\end{array}
$$

Cathode: $\quad \mathrm{F}_{2}+2 \mathrm{e}^{-} \rightarrow 2 \mathrm{~F}^{-}$

Therefore, $\mathrm{CO}_{2}+\mathrm{F}_{2} \rightarrow \mathrm{COF}_{2}+1 / 2 \mathrm{O}_{2}$. As shown above, the tetragonal $\mathrm{PbSnF}_{4}$ [7-21] is 
known as a fluoride ion conductor having high electric conductivity at ambient temperature. The $\mathrm{CO}_{2} / \mathrm{F}_{2}$ electrochemical cell was constructed using tetragonal $\mathrm{PbSnF}_{4}$ with $\mathrm{Au}$ electrodes as the solid electrolyte; its performance was investigated using emf and impedance measurements.

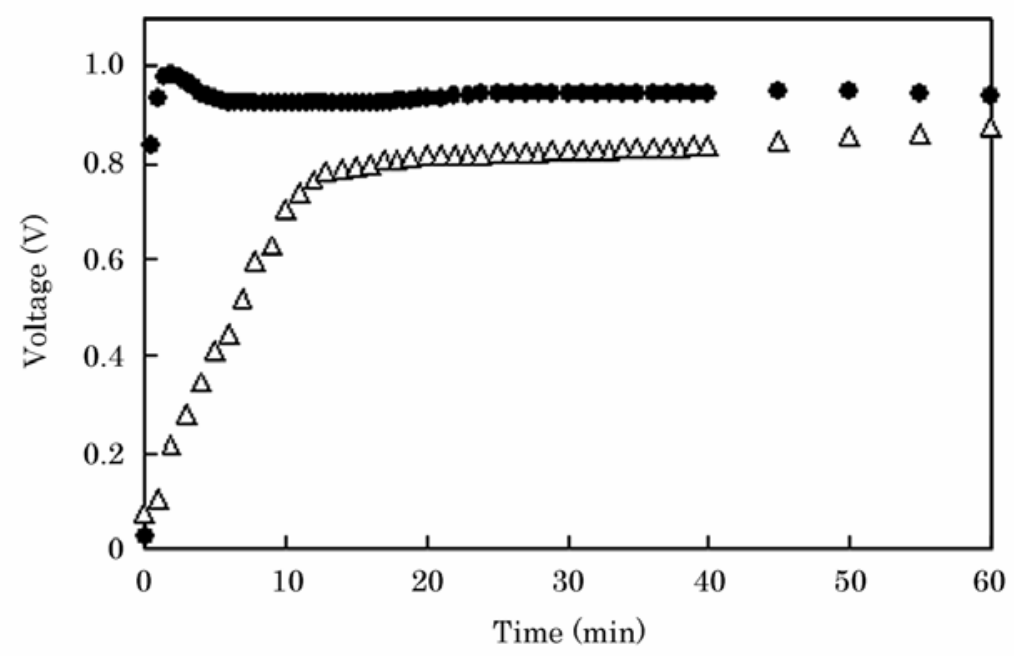

Fig. 2.13. The change in emf over time. Anode gas was $0.1 \mathrm{MPa} \mathrm{CO}_{2}$ and cathode gas was $\chi \mathrm{MPa} \mathrm{F}+(0.1-\chi) \mathrm{MPaAr} .(\mathbf{\bigcirc} \chi \chi=0.02, \triangle: \chi=$ $0.01)$

Fig. 2.13 shows results of emf measurements under conditions of $0.1 \mathrm{MPa} \mathrm{CO}_{2} /(0.02$ $\left.\mathrm{MPa} \mathrm{F}_{2}+0.08 \mathrm{MPa} \mathrm{Ar}\right)$ and $0.1 \mathrm{MPa} \mathrm{CO}_{2} /(0.01 \mathrm{MPa} \mathrm{F}+0.09 \mathrm{MPa} \mathrm{Ar})$. The respective emf values were about $0.93 \mathrm{~V}$ and $0.86 \mathrm{~V}$ at $0.02 \mathrm{MPa} \mathrm{F}_{2}$ and $0.01 \mathrm{MPa} \mathrm{F} 2$ in $\mathrm{Ar}$. The measured emf value was about $80 \%$ of the theoretical one of $1.14 \mathrm{~V}$. The difference between the emf value for $10-20 \% \mathrm{~F}_{2}$ in Ar was calculated as $0.009 \mathrm{~V}$. Commonly, the chemical potential becomes lower by the interfacial resistance of the electrolyte and the electrode or the crossleak. Although some points require improvement, a $\mathrm{CO}_{2} / \mathrm{F}_{2}$ 
electrochemical cell can probably be constructed sufficiently with $\mathrm{PbSnF}_{4}$ as a solid electrolyte. However, the measured short circuit current density was $0.24 \mathrm{~A} \mathrm{~m}^{-2}$, which was quite small.

Fig.2.14 shows Cole-Cole plot of tetragonal $\mathrm{PbSnF}_{4}$ in the electrochemical cell. Fist, the impedance was measured under the condition of $0.1 \mathrm{MPa} \mathrm{Ar} / 0.1 \mathrm{MPa} \mathrm{Ar}$ at anode and cathode sides. And then, Ar gas was eliminated from the cathode side and substituted by $\mathrm{F}_{2}$ gas. The charge transfer resistance and double layer capacitance changed by contacting $\mathrm{F}_{2}$ gases to the electrolyte.

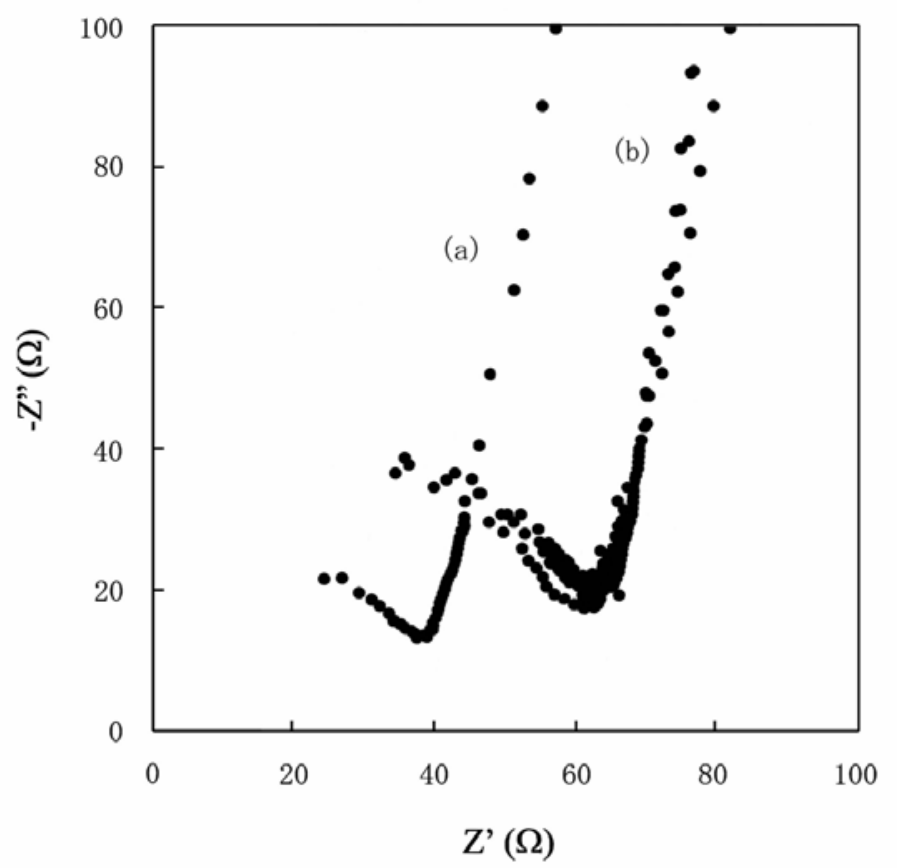

Fig. 2.14. Cole-Cole plot of tetragonal $\mathrm{PbSnF}_{4}$ between $1 \mathrm{~Hz}$ and $500 \mathrm{kHz}$ at $373 \mathrm{~K}$. (a) Anode and cathode gases were Ar, (b) anode gas was Ar, cathode gas was $\mathrm{F}_{2}$ gas. 
It is important to mention here that the resistance, capacitance and impedance changed and became large by the effect of $\mathrm{F}_{2}$ gas during the measurement. Apparently, the current value did not increase according to the effects of the morphological stability of electrode against $\mathrm{F}_{2}$ gas. The electrolyte and the electrode interface might be very sensitive to $\mathrm{F}_{2}$ gas, and the charge transfer process and mass transfer process might be affected by the exposure time of the sample under the $\mathrm{F}_{2}$ environment.

The absorption peaks of fluorocarbon compound did not appear in the FT-IR spectra in which $1200-1300 \mathrm{~cm}^{-1}$ and around $1930 \mathrm{~cm}^{-1}$ corresponded to $\mathrm{C}-\mathrm{F}$ and $\mathrm{CF}=\mathrm{O}$ bonds, respectively. The current density was so small that the reaction between $\mathrm{CO}_{2}$ and $\mathrm{F}_{2}$ could not take place sufficiently and no fluorocarbon compound was detectable after $3 \mathrm{~h}$ discharge using FT-IR.

\section{References and Notes}

[1] I. Omae, Nisankatannso to Tikyukankyou, Tyukousinnsho (1999) pp.23-142. http://cdiac.esd.ornl.gov/trens/emis/em_cont.htm.

[2] Y. Matsumoto, M. Obata, and J. Hombo, J. Phys. Chem. 98 (1994) 2950-2951.

[3] W. M. Sears and S. R. Morrison, J. Phys. Chem. 89 (1985) 3295-3298.

[4] Y. Hasegawa, R. Otani, S. Yonezawa, M. Takashima, J. Fluorine Chem. 128 (2007) $17-28$.

[5] J. C. Amphlett, J. R. Dacey, G. O. Pritchard, J. Phys. Chem. 75 (1971) 3024-3026.

[6] W. M. Latimer, The Oxidation States of the Elements and their Potentials in Aqueous Solutions (Prentice Hall, New York, 1952).

[7] D. J. Donaldson, B. J. Senior, J. Chem. Soc. (A) 1821-1825 (1967). 
[8] J. M. Reau, C. Lucat, J. Portior, P. Hagenmuller, L. Cot, S. Vilminot, Mat. Res. Bull. $13(1978) 877-882$.

[9] J. Pannetier, G. Denes, J. Lucas, Mat. Res. Bull. 14 (1979) 627-631.

[10] G. Perez, S. Vimont, W. Granier, L. Cot, C. Lucat, J. M. Reau, J. Portior, P. Hagenmuller, Mat. Res. Bull. 15 (1980) 587-593.

[11] G. Denes, M. C. Madamda, A. Muntasar, A. Peroutka, K. Tam, and Z. Zhu, Nato, Sci. Ser. 25-38 (1999).

[12] G. Denes, J. Solid State Chem. 77 (1988) 54-59.

[13] G. Denes, T. Birchall, M. Sayer, M. F. Bell, Solid State Ionics 13 (1988) 213-219.

[14] Y. Ito, T. Mukuyama, H. Funatomi, S. Yoshikado, T. Tanaka, Solid State Ionics 67 (1994) 301-305.

[15] R. Kanno, K. Ohno, H. Izumi, T. Kamiyama, H. Asamo, F. Izumi,Y. Solid State Ionics 70-71 (1994) 253-258.

[16] G. Denes, Y. H. Yu, T. Tyliszczak, A. P. Hitchcock, J. Solid State Chem. 91 (1991) $1-15$.

[17] M. M. Ahmad, K. Yamada, T. Okuda, J. Phys.: Condens. Matter 14 (2002) $7233-7244$.

[18] S. Suda, T. Eguchi, J. Kuwano, Key Engineering Materials 181-182 (2000) 203-206.

[19] A. Wakagi, J. Kuwano, Y. Saito, J. Mater. Chem. 41 (1994) 973-975.

[20] T. Eguti, S. Suda,T. Hijii, S. Koga, J. Kuwano, Y. Saito, Key Engineering Materials 181-182 (2000) 199-202.

[21] A. Wakagi, J. Kuwano, M. Kato, H. Hanamoto, Solid State Ionics 70-71 (1994) 601-605.

[22] G. Denes, G. Milova, M. C. Madamda, M. Perfiliev, Solid State Ionics 86-88 (1996) $77-82$. 
[23] M. J. Sienko, R. A. Plane, Chemistry: Principles and Properties (McGraw-Hill, Inc. 1966).

[24] J. B. Goodenough, Pure \& Appl. Chem. 67 (1995) 931-938.

[25] A. J. Bard and L. R. Faulkner, Electrochemical Methods; Wiley \& Sons: New York, 2001; Chapters 3, 5, 7, 10, 13

[26] W. Schmickler, Interfacial Electrochemistry; Oxford University Press: Oxford, 1996.

[27] J. E. B. Randles, Discuss. Faraday Soc. 1 (1947) 11-19.

[28] J. E. B. Randles, Trans. Faraday Soc. 44 (1948) 327-338.

[29] J. E. B. Randles, Trans. Faraday Soc. 52 (1956) 1573-1581.

[30] R. Parsons, Chem. Rev. 90 (1990) 813-826.

[31] Y. Li, J. Gao, G. Yu, Y. Cao, A. J. Heeger, Chem. Phys. Lett. 287 (1998) 83-88.

[32] F. Izumi and T. Ikeda, Mater. Sci. Forum 321-324 (2000) 198-203.

[33] J. B. Wagner and J. C. Wagner, J. Chem. Phys. 26 (1957) 1597-1601.

[34] Joint Committee for Powder Diffraction Standards (JCPDS), International Centre For Diffraction Data.

[35] R. Kanno, S. Nakamura, K. Ohno, Y. Kawamoto, Mat. Res. Bull. 26 (1991) $1111-1117$. 


\section{Chapter 3}

\section{Conclusion and future work}

\subsection{Conclusion}

From the results presented, it is confirmed that the reaction between $\mathrm{CO}_{2}$ and $\mathrm{F}_{2}$ for preparation of $\mathrm{COF}_{2}$ takes place spontaneously. $\mathrm{A} \mathrm{CO}_{2} / \mathrm{F}_{2}$ electrochemical cell produced enough open circuit voltage about $0.9 \mathrm{~V}$, while it could produce quite small amount of electric power.

\subsubsection{Chapter 1}

By the reaction between $\mathrm{CO}_{2}$ and $\mathrm{F}_{2}, \mathrm{COF}_{2}$ was obtained at high yield in conditions of $473 \mathrm{~K}$ during $50 \mathrm{~h}$ in a direct reaction. The by-products were $\mathrm{CF}_{3} \mathrm{OF}$ and $\mathrm{CF}_{4}$. All of $\mathrm{NaF}, \mathrm{CsF}$ and $\mathrm{EuF}_{3}$ were tested as catalysts. Results showed that $\mathrm{CsF}$ can play a role as the catalyst. The $\mathrm{COF}_{2}$ formation rates in the presence of $\mathrm{CsF}$ were five times larger than that without catalyst. Using $\mathrm{CsF}$, the yields of $\mathrm{COF}_{2}$ and $\mathrm{CF}_{3} \mathrm{OF}$ become higher than that in the direct reaction for temperatures of $373-473 \mathrm{~K}$. In addition, $\mathrm{CF}_{2}(\mathrm{OF})_{2}$ was produced at $303 \mathrm{~K}$ and its yield decreased with increasing temperature; $\mathrm{CF}_{3} \mathrm{OOCF}_{3}$ was detected more at $473 \mathrm{~K}$. Yields of $\mathrm{COF}_{2}$ and $\mathrm{CF}_{3} \mathrm{OF}$ become higher than that in the 
direct reaction at temperatures of $373-473 \mathrm{~K}$. The slightly lower amount of $\mathrm{CF}_{4}$ less than $0.1 \%$ was produced in this case. The $\mathrm{CsF}$ affected the reaction pathways. For the reaction without $\mathrm{CsF}$, the $\mathrm{F}^{\cdot}$ formation plays an important role in the products' composition. Considering that $\mathrm{COF}_{2}$ is converted into $\mathrm{CF}_{3} \mathrm{OF}$, the best yield of $\mathrm{COF}_{2}$ was $11.1 \%$ under the reaction conditions of $\mathrm{CO}_{2} / \mathrm{F}_{2}=76 \mathrm{kPa} / 76 \mathrm{kPa}$, with temperature of $498 \mathrm{~K}$ and $72 \mathrm{~h}$ reaction time in the direct reaction. The reaction mechanism in the presence of $\mathrm{CsF}$ can be explained using the formation of possible reaction intermediates $\left[\mathrm{CF}_{2}(\mathrm{OF}) \mathrm{O}^{\delta-} \mathrm{Cs}^{\delta+} \mathrm{F}\right]$ and $\left[\mathrm{CF}_{3} \mathrm{O}^{\delta-} \mathrm{Cs}^{\delta+} \mathrm{F}\right]$ at each temperature. The best yield of $\mathrm{COF}_{2}$ was $6.5 \%$ under the reaction conditions of $\mathrm{CO}_{2} / \mathrm{F}_{2}=76 \mathrm{kPa} / 76 \mathrm{kPa}$ with $473 \mathrm{~K}$ reaction temperature and $50 \mathrm{~h}$ reaction time.

\subsubsection{Chapter 2}

Tetragonal $\mathrm{PbSnF}_{4}$, which had higher electrical conductivity than orthorhombic $\mathrm{PbSnF}_{4}$, was prepared by adding $\mathrm{Pb}\left(\mathrm{NO}_{3}\right)_{2}$ aqueous solution to $\mathrm{SnF}_{2}$ aqueous solution at dropping speed of $500 \mathrm{~mm}^{3} \mathrm{~s}^{-1}$ at room temperature. The tetragonal $\mathrm{PbSnF}_{4}$ exhibited conductivity of $3.2 \mathrm{Sm}^{-1}$ at $473 \mathrm{~K}$ in air.

$\mathrm{A} \mathrm{CO}_{2} / \mathrm{F}_{2}$ electrochemical cell was constructed using tetragonal $\mathrm{PbSnF}_{4}$ with $\mathrm{Au}$ electrodes as the solid electrolyte. The electromotive force was about $0.9 \mathrm{~V}$ at room temperature under conditions of $0.1 \mathrm{MPa} \mathrm{CO} /$ / (0.01 $\left.\mathrm{MPa} \mathrm{F}_{2}+0.09 \mathrm{MPa} \mathrm{Ar}\right)$. The short circuit current density was measured as $0.24 \mathrm{~A} \mathrm{~m}^{-2}$.

The content of the fluorocarbon compound as the product was so low that it could not be detected. 


\subsection{Future work}

None of the $\mathrm{CO}_{2} / \mathrm{F}_{2}$ fuel cell device systems has been reported to date. We have proposed a new energy cycle with $\mathrm{CO}_{2}$ fixing process, and reported the performance of $\mathrm{CO}_{2} / \mathrm{F}_{2}$ electrochemical cell. There has been a tremendous interest because of the potential for the energy cycle including the reaction between $\mathrm{CO}_{2}$ and $\mathrm{F}_{2}$ as one method for $\mathrm{CO}_{2}$ fixation. The prospect of using a $\mathrm{CO}_{2} / \mathrm{F}_{2}$ electrochemical cell as an application for $\mathrm{CO}_{2}$ fixation would be very appealing and has a deep impact on our society.

Our study has led to a significant progress in understanding a $\mathrm{CO}_{2} / \mathrm{F}_{2}$ fuel cell and its reactions. However, its performance was very low. It indicates that the $\mathrm{CO}_{2} / \mathrm{F}_{2}$ fuel cell had many difficulties. The poor chemical stability of the materials limited the all performances. The fundamental study to design the materials which are anti-corrossive by $\mathrm{F}_{2}$ might contribute to solve it. 


\section{List of publications}

\section{Journal papers:}

[1] "Reaction between carbon dioxide and elementary fluorine," Yasuo Hasegawa, Reiko Otani, Susumu Yonezawa, Masayuki Takashima, J. Fluorine Chem., 128, 17-28 (2007).

[2] "Preparation of $\mathrm{COF}_{2}$ using $\mathrm{CO}_{2}$ and $\mathrm{F}_{2}$ in the electrochemical cell with $\mathrm{PbSF}_{4}$ as a solid electrolyte," Yasuo Hasegawa, Akitomo Nagasaka, Jae-Ho Kim, Susumu Yonezawa, Masayuki Takashima, J. Fluorine Chem., 128, 958-964 (2007).

\section{Conference papers:}

[1] "Reaction between carbon dioxide and elementary fluorine," Satoshi Ueda, Yasuo Hasegawa, Susumu Yonezawa, Masayuki Takashima, International Chemical Congress of Pacific Basin Societies, Honolulu, Hawaii, December, 2000, Book of Abstracts, P. 1487.

[2] "The reaction between carbon dioxide and elementary fluorine in the presence of various fluorides," Reiko Otani, Yasuo Hasegawa, Susumu Yonezawa, Masayuki Takashima, Fusso Kagaku Touronkai Koen Youshishu, Vol. 25th, 109-111 (2001).

[3] "Preparation of $\mathrm{PbSF}_{4}$ as a solid electrolyte," Akitomo Nagasaka, Hidezi Fukaya, Shigeyuki Kimura, Yasuo Hasegawa, Susumu Yonezawa, Masayuki Takashima, The International Conference on Fluorine Chemistry, Kyoto, Japan, May, 2004, Book of Abstracts, P. 8. 
[4] 二酸化炭素とフッ素ガスの反応, Hiroyasu Otsuka, Masaru Miyamoto, Yasuo Hasegawa, Susumu Yonezawa, Masayuki Takashima, 第 21 回フッ素化学討論会講演 予稿集, P-09, 112 (1997).

[5] 二酸化炭素とフッ素ガスの反応, Hiroyasu Otsuka, Masaru Miyamoto, Yasuo Hasegawa, Susumu Yonezawa, Masayuki Takashima, 日本化学会北陸地区講演会予 稿集, D-12, 68 (1997).

[6] 二酸化炭素とフッ素ガスの反応, Masaru Miyamoto, Satoshi Ueda, Yasuo Hasegawa, Susumu Yonezawa, Masayuki Takashima, 日本化学会北陸地区講演会予稿集, D-12, 68 (1999)

[7] フッ素一二酸化炭素の直接反応に関する触媒の検討, Reiko Otani, Takashi Yagi, Satoshi Ueda, Yasuo Hasegawa, Susumu Yonezawa, Masayuki Takashima, H12 年 度日本化学会北陸地区講演会予稿集, D-13 (2000).

[8] フッ素－二酸化炭素の直接反応機構の解析, Reiko Otani, Yasuo Hasegawa, Susumu Yonezawa, Masayuki Takashima, H13 年度日本化学会北陸地区講演会予稿集, D-10 (2001). 


\section{Articles of other works}

\section{Journal papers:}

[1] 水中におけるミッシュメタルの発火危険性, Tadashi Uno, Yasuo Hasegawa, Takashi Yamamuro, 安全工学, 27, 157-161 (1988).

[2] M m N i A 1 系水素吸蔵合金のアルカリ水溶液中での表面変化と電気化学挙動, Masayuki Takashima, Yuiti Matsumura, Yasuo Hasegawa, Gentarou Kanou, Keiiti Hasegawa, Masahiko Oshitani, Yuji Matsumaru, 電気化学 60, 231-238 (1992).

[3] ミッシュメタルの物性に関する研究, Yasuo Hasegawa, 警察庁法科学研修所研究報告集, 139-156 (1992).

\section{Conference papers:}

[1] D I ／M S よよるポリマーの定性, Yasuo Hasegawa, Tadashi Uno, 鑑識科学研究発表会 講演集（1990）.

[2] Mm N i A 1 系水素吸蔵合金の充放電反応およぼすコバルトの影響（1），Masayuki Takashima, Yuiti Matsumura, Yasuo Hasegawa, Gentarou Kanou, 電気化学協会北 陸支部 30 周年記念大会, B19 (1991).

[3] Mm N i A 1 系水素吸蔵合金の充放電反応およぼすコバルトの影響（2），Masayuki Takashima, Yuiti Matsumura, Yasuo Hasegawa, Gentarou Kanou, 電気化学秋季大 会, 2F27 (1991).

[4] 基本的な高分子熱分解物の昇温 E I /C I M S 法による検討, Yasuo Hasegawa, 第 28 回北陸質量分析談話会 (1993). 
[5] 昇温 E I ／C I M S 法，T G ／M S 法による基本的な高分子化合物のマススペクトルの 比較, Yasuo Hasegawa, 日本鑑識科学技術学会第 1 回学術集会講演要旨集, C-10, 50 (1995).

[6] "Preparation and properties of neodymium-europium oxide," Masayuki Takashima, Susumu Yonezawa, Yasuo Hasegawa, A. Unishi, International Chemical Congress of Pacific Basin Societies, Honolulu, Hawaii, December, 1995, Book of Abstracts, P. 1666.

[7] Kinetic Method によるメタンフェタミンのプロトン親和力測定の試み, Shigeki Matsumura, Tetuya Tsukahara, Yasuo Hasegawa, Hideyuki Takezawa, Kimio Isa, 日本鑑識科学技術学会第 6 回学術集会講演要旨集, C-5, 50 (2000).

\section{Books:}

[1] 薬物事犯対策のための調査研究報告（パラオ共和国）, Kimiyoshi Nakano, Satoru Onishi, Yoshiaki Maedomari, Yasuo Hasegawa, Shinji Kabayashi，（財）全国防犯協 会連合会, 1999 . 